Historic, Archive Document

Do not assume content reflects current scientific knowledge, policies, or practices. 



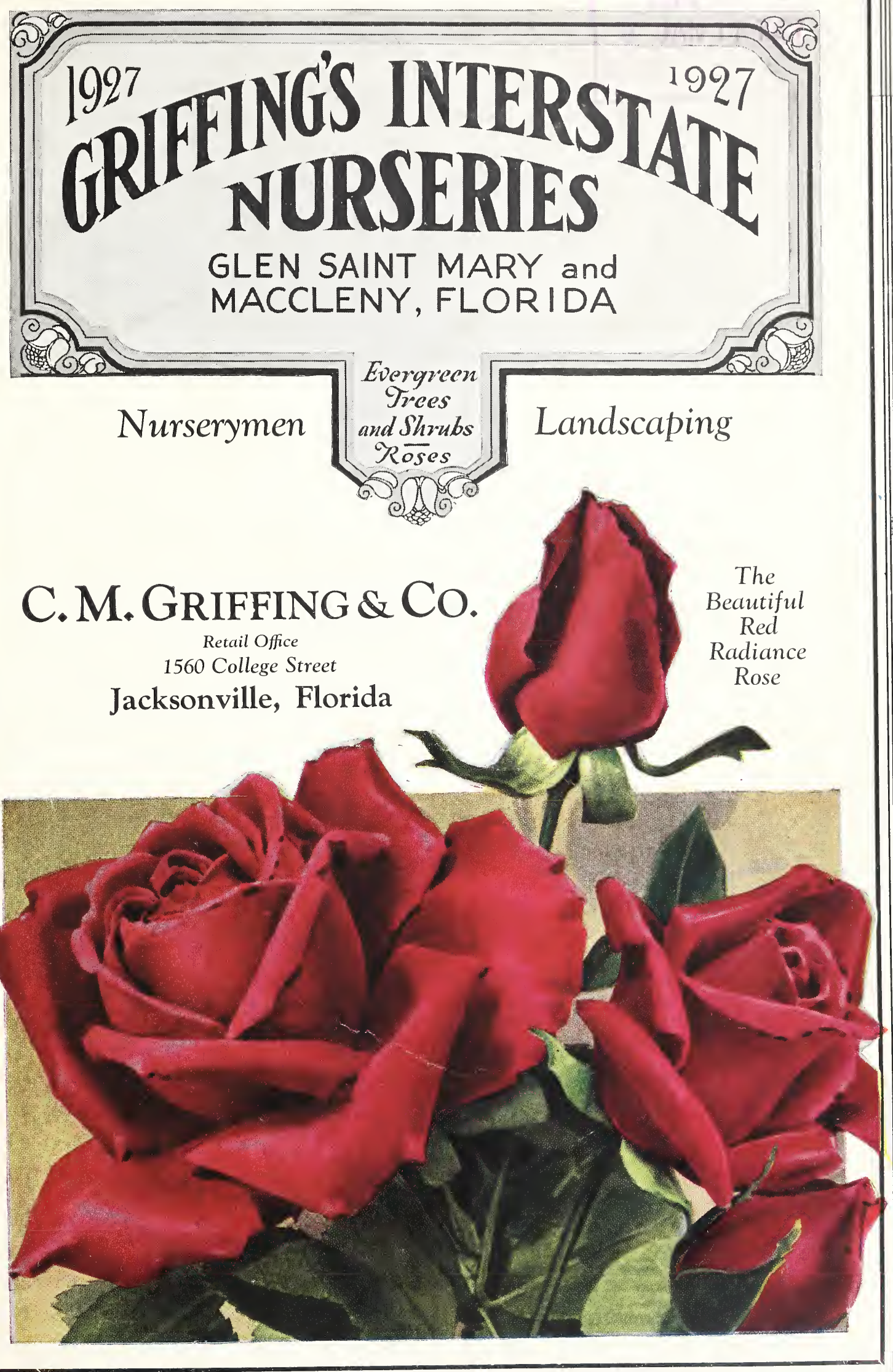



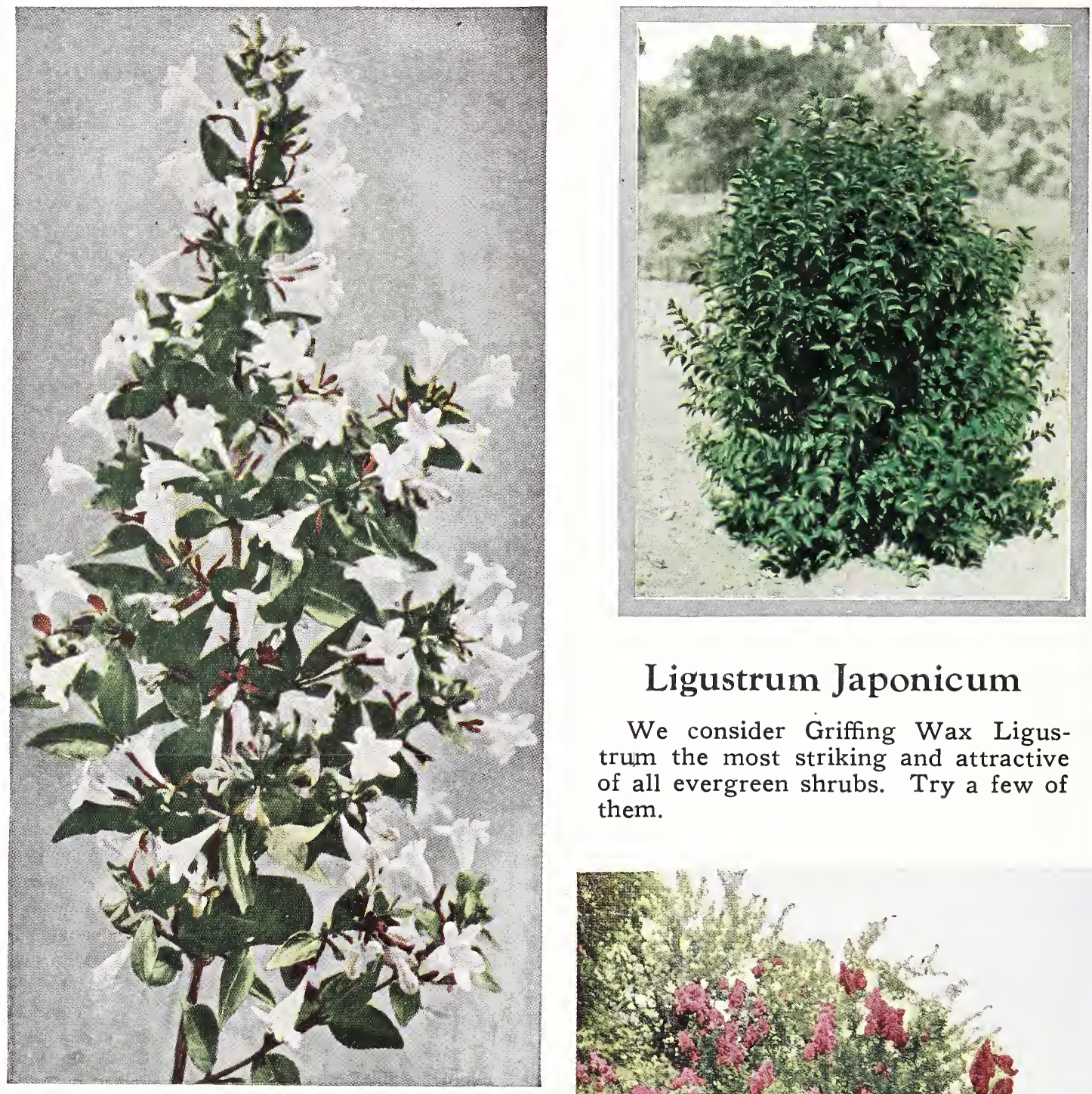

\section{Ligustrum Japonicum}

We consider Griffing Wax Ligustrum the most striking and attractive of all evergreen shrubs. Try a few of them.

\section{Abelia Grandiflora}

One of the most desirable and beautiful shrubs for the South.

Flowering shrubs are needed to give your grounds a complete, pleasing effect. The profusion of bloom affords you joy and contentment. Include a few in your order. Our list includes the best for the South.

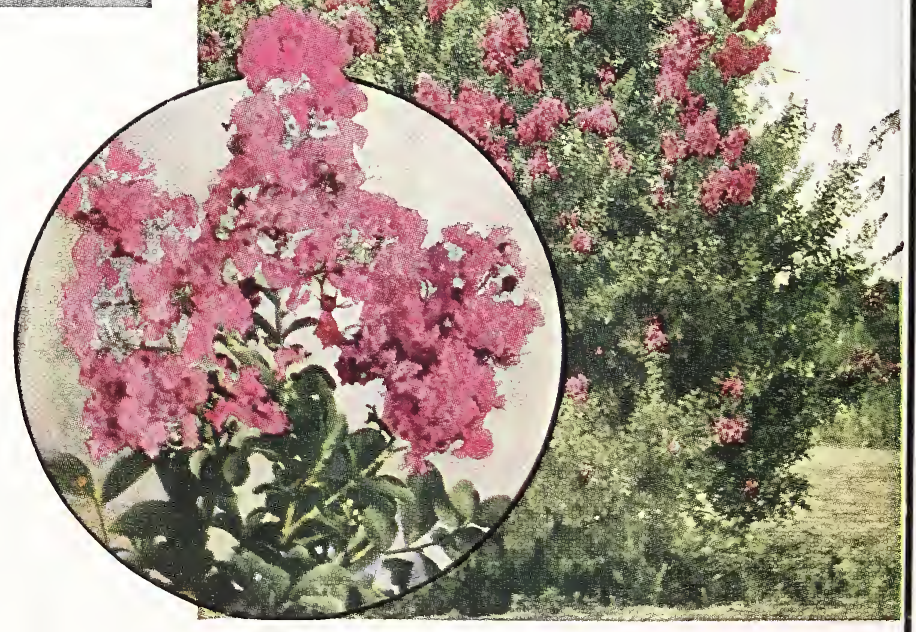

\section{Crape Myrtle}

This popular tree, or shrub, is always admired. Blooms during Spring and Summer. 


\section{Griffing}

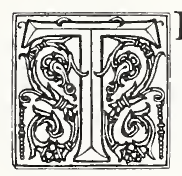

HE NAME “GRIFFING” really needs no introduction, for the Griffings have been known throughout the South for over thirty-five years, having in that time furnished their many friends fruit and ornamental stock of the best quality grown. However, in recent years, particularly in the South, the value of Home Ground Beautification has come into prominence and in order to handle the large volume of business where Landscape service is required, we have deemed it necessary to create a Landscape Department. Our desire is that in this way we may more efficiently handle the needs of our patrons.

\section{GRIFFING'S INTERSTATE NURSERIES}

Office: 1560 College St., Jacksonville, Fla.

Nurseries: Glen St. Mary and Macclenny, Fla.

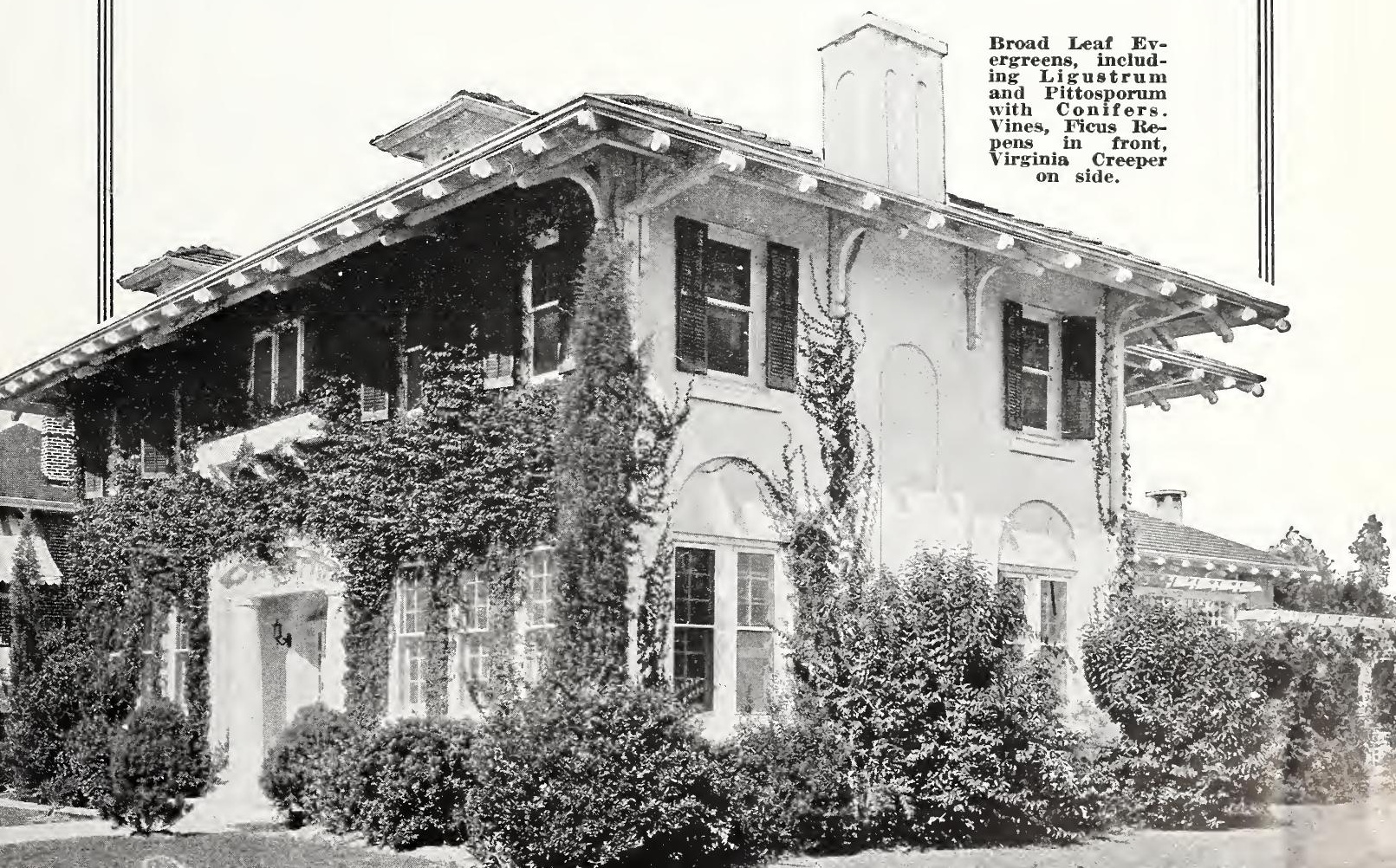




\section{Suggestions About Ordering}

Patrons will oblige us, and avoid possible errors, omissions and misunderstandings by using order blank, and observing the following suggestions and terms of sale. More order blanks will be cheerfully furnished upon request.

Write Plainly, Your signature, postoffice, street or $\mathbf{R}$. F. D. address; name of consignee, destination and route; if a new or small town, give name of county, railroad or river. Designate whether shipment is preferred by express, freight, or mail. Use separate line for each item ordered.

Indicate size wanted by writing size in figures, or as listed in catalog. Extend or carry out prices for each item or group of the same class having a common price.

- Many nurseries and dealers buy and sell our stock. Trees or plants sold to nurseries or dealers must be reTrees or plants sold to nurseries or dealers must be re-
sold by them on their own responsibility. We are responsible only to parties purchasing direct from us.

\section{PRICES}

Prices Are Graduated according to size or age of trees and plants and quantity ordered. Orders for any one class or size of trees having a common price made up of one or more varieties, graduate price applies as follows :

1 to 4 trees, single or each price applies.

5 to 50 trees, ten rate price applies.

5 to 500 trees, hundred rate price applies.

500 or more trees, thousand rate price applies.

This does not, however, apply to long lists of one or two trees each; on such the ten rate should apply.

Prices in this Catalog are for goods properly packed and delivered in good condition to forwarding company, the purchaser assuming all cost and risk of transportation.

Parcel Post Shipments of small sizes will be made for twenty-five per cent advance over list prices.

\section{OUR LIABILITY}

We exercise all possible care to have stock well rooted, well grown, healthy, true to name, properly packed, and shipped according to instructions. It is, however, mutually agreed between the purchaser and ourselves that our liability under the foregoing is limited in amount to original price received. No guarantee expressed or implied that trees will live or grow.

It is to your advantage to order early, as it is almost impossible during the rush of the planting season to fill an order on short notice, without injustice to those who have their orders previously booked. And, while our stock is most complete this year, yet if you do not place your order early, the varieties you especially desire may have become exhausted. Send us your order as soon as possible, and let us reserve that particular stock you want, for shipment when you are ready to plant. Twentyfive per cent deposit will secure orders for future shipment.

\section{REMITTANCES}

To insure safety and prompt acceptance, we ask that remittance be made by Bank Drafts, Express or Post Office Money Orders or through Registered Letters. We Office Money Orders or through Registered Letters. We
do not care to make C. O. D. shipments and will not, unless twenty-five per cent of amount accompanies orders. No orders filled for less than $\$ 2.00$. Our terms are Cash.

\section{SHIPMENTS}

Unless otherwise instructed, orders received during shipping season will be forwarded as soon after receipt as possible. Reserve orders will be shipped as soon as convenient after shipping season opens.

Orders Without Shipping Instructions will be shipped as we believe is safest, cheapest and best for our customers' interest. Should shipment be ordered by freight, and we find that express rates for the size package are nearly or quite as cheap, we will forward by express.

Shipments at Purchaser's Risk. Our responsibility ceases when we deliver trees to forwarding company. Claims for loss or damage must be made on them. We will, however, trace, if requested, and use every means at our command to secure prompt delivery, and recovery in case of damage or loss.

\section{SELECTION OF VARIETIES}

Selection of varieties suitable to your locality is of first importance, and can often be more advantageously done by us than by purchaser. We will gladly aid our patrons in their selections and upon request furnish information as to adapability and desirability of varieties.

\section{SUBSTITUTION}

We desire to follow our customers' wishes in this respect, and have found that they usually wish us to substitute to the best of our judgment in case we are out of any varieties or sizes ordered. We therefore sub. stitute when necessary unless instructed to the contrary.

Inspection. Every shipment we send out will carry a certificate of inspection. Immediately upon making the shipment, we mail to the Plant Board a manifest with the name of the party to whom shipped, giving a list of contents and where stock is grown.

Errors and Omissions. With the best of us, mistakes sometimes occur. If our customers will notify us promptly, we will cheerfully rectify any mistakes that may occur.

Our nurseries are always open to visitors. Inspection will prove our products are the best that experience, good cultivation and favorable conditions can produce.

Our nurseries are located twenty-eight miles west of Jacksonville, Fla., on the Seaboard Airline Railway and the National Highway, one of the best concrete roads in the state, being a main artery of travel connecting with Lake City, Gaineville and Tampa, Fla. It is always a pleasure to show visitors our stock; If notified in advance, we will be pleased to meet you at station or bus line. Our Jacksonville office is located at 1560 College street. When in Jacksonville call to see us. 


\section{Landscaping the Home}

THERE is no place on earth that possesses greater natural advantages for Beautiful Home Grounds than the South; nature has done so much in supplying trees and shrubs that very often man merely selects a spot already shaded and made beautiful with the natural growth on which to build his home. For the pioneer this was most desirable, but, as the country is settled, rural roads laid out on section lines and towns and cities laid out in blocks, there is but little of the natural growth that can be utilized; and here is where the natural advantages of the southern climate and soil, so admirably adapted to the rapid growth and development of trees, shrubbery and palms, make it possible to change (as if by magic) the bare ground into beautiful lawns having the proper setting of trees, shrubs and flowering beds, quicker and better than anywhere else.

The home is the pivot on which life revolves, and deserves to be made as cheerful and attractive as means will permit. Heretofore it was the custom to select such plants or trees as suited our fancy and place them in a haphazard manner about the premises. As is usally the case, we often discover we have unconsciously planted unwisely.

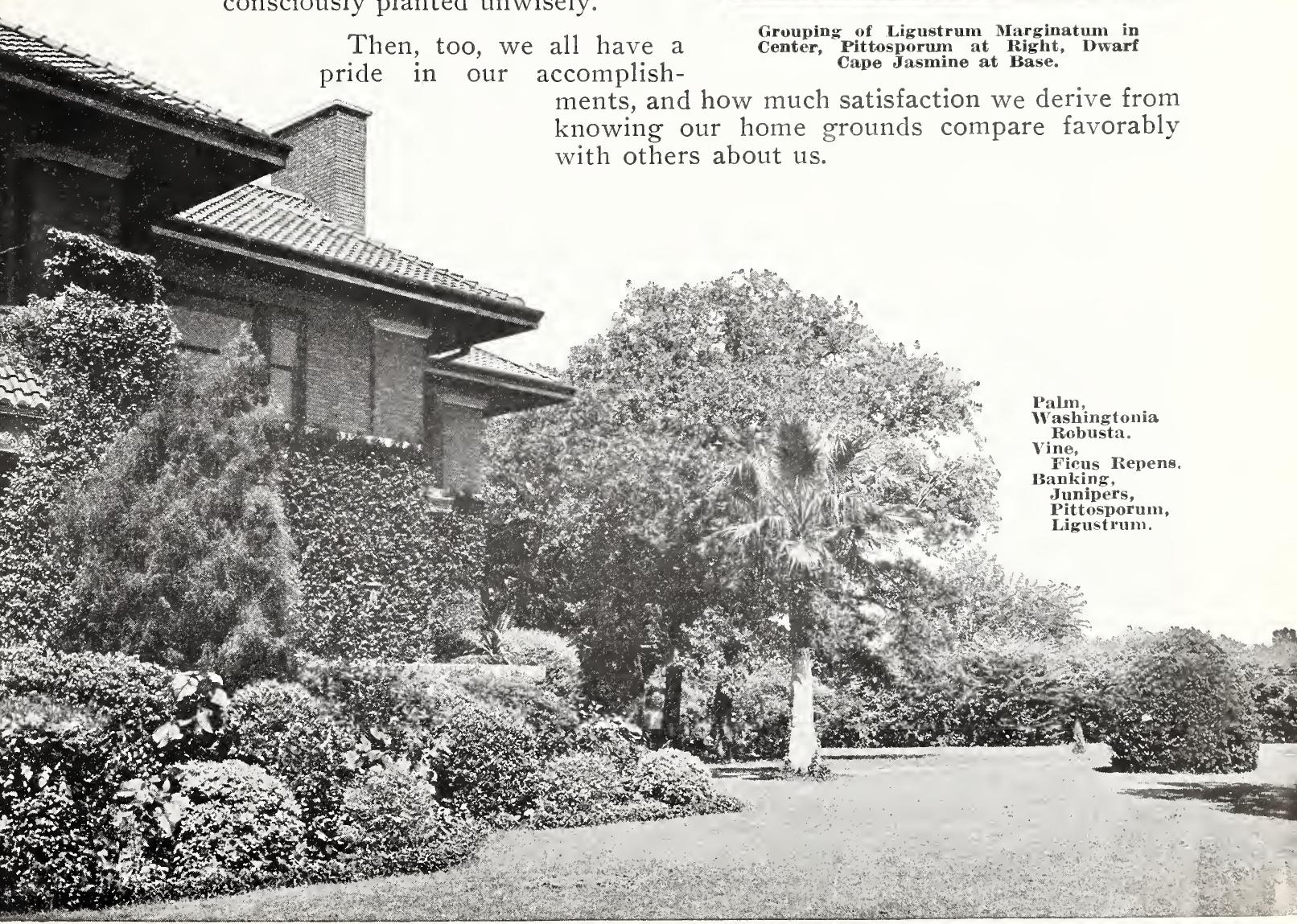




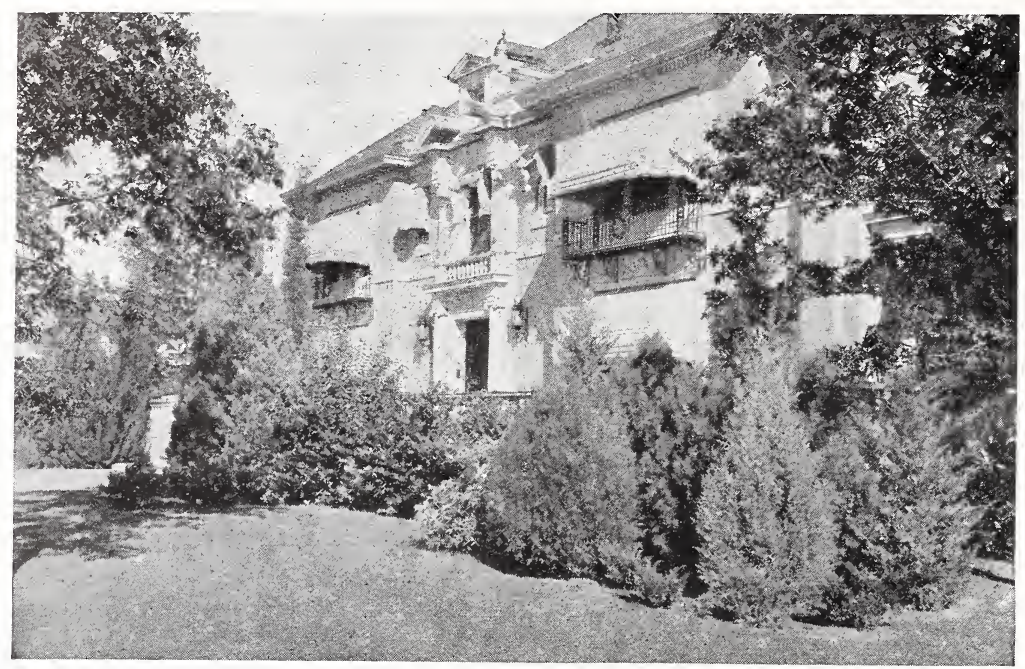

Junipers, Cypresses and Ligustrums Properly Arranged.

\section{The Value of Landscape Planting}

I OOK about you and see how accurately you can judge your neighbors without $L$ entering their homes. Outside appearances count. Hundreds see the exterior to one who enters the home. Landscaped home grounds are as essential as furniture and decorations inside and are far more conspicuous and prominent.

Time was when a home owner bought the few plants he loved or happened to know and planted them where he chose. Today: the home grounds are in the primary considerations of home building. Shrubs must be planted generously and properly to be in keeping with good taste.

Beautiful Shrubs increase your property value, make your grounds and house more home-like and a far more desirable place to live. They add distinctiveness and

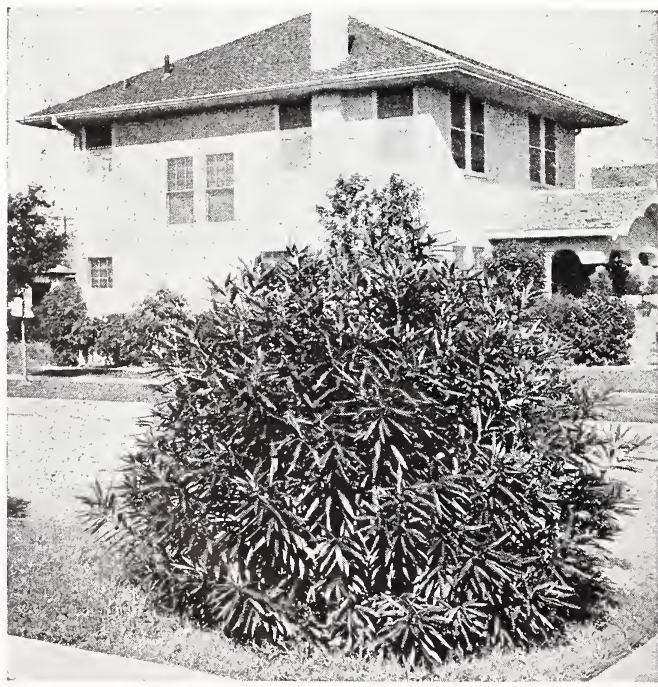

Oleander. individuality to your property and increase in beauty with the years. The most expensive house is still just a house until the grounds are so planted as to bring out its home qualities and beau. ties. The smallest cottage or bungalow is not rivalled in beauty by the largest mansion if it is properly planted and the grounds well arranged.

Don't envy a neighbor's landscape display. Resolve to have a better one of your own. We will help you by telling you how and furnishing plants that will give best results. 


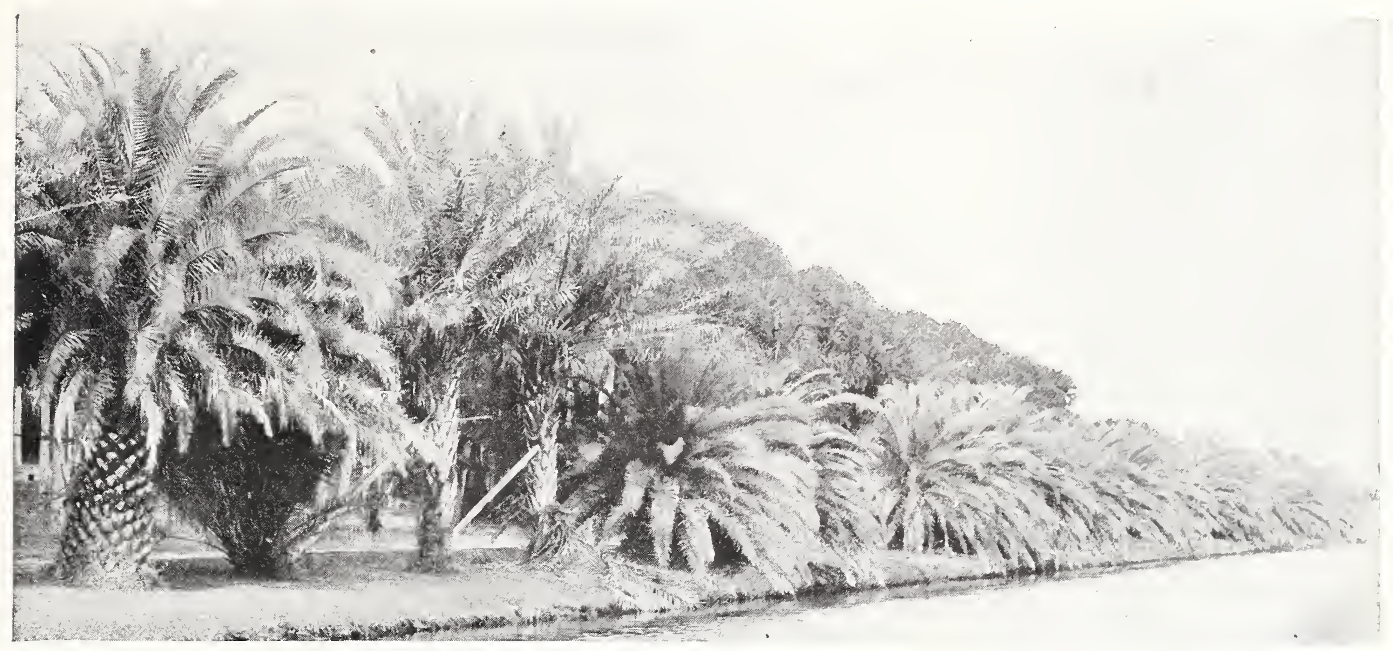

\section{Why Real Estate Dealers and Land Promoters Should Be Interested In Our Landscape Service}

WITH the coming of subdivisions all over the South like so many mushrooms, we are about to be confronted with a problem far greater than we first imagined. These subdivisions are invading almost every nook and corner of this section of the country. Many are, of course, being operated on a well-planned method, while others have no signs of any beauty or home-like atmosphere.

In the past, too many subdivisions have been laid out without thought or consideration to the future beauty of the land and for the interest of the individual home dweller. In too many cases we have actually noticed the existing natural beauty ruthlessly slashed and destroyed through sheer ignorance and greed. As a result the home owner has not received what God really intended he should have for his joy and contentment.

Unless the ones developing these subdivisions take this into consideration, it will only rebound to their discredit and in the end possibly cause financial loss. To entirely overlook this feature of development, will make it more difficult to find purchasers as well as increase the actual cost of selling. With no inducement other than the mere land, it becomes a task to move the property quickly, for it will repel rather than appeal to the one seeking a pleasant place in which to set his or her abode.

Without any doubt whatever it can be safely said that the cheapest way to develop a subdivision is by presenting it in the most attractive manner to the prospective buyer. The developer must keep in mind the essential factors required to make his subdivision attractive and then diligently seek to carry out the idea or plan whereby it may be obtained. The streets are generally first thought of and they should be lined out with trees cr palms. It is said that even one tree sometimes adds hundreds of dollars to the value of the land and yet many times a tree is simply torn down to make way for some supposed improvement. They are often brought down when a little discretion or thought could have preserved them. Such needless destruction is usually associated with real estate developers who do not have the faintest idea of the value of a tree.

Then, we have the parks. No subdivision is a success until it has included parks in the layout of the grounds. Parks are a necessity, they pro- vide the open air and sunlight demanded by children, as well as grown ups, and afford a place for recreation which is essential to health and happiness. But, rather no parks at all than to have them an eyesore for lack of proper care. Unless some arrangement can be made to maintain them in good order, it would be far better to turn the land allotted over to the property owners and give them the chance to beautify.

The streets in a subdivision should be beautified in a like manner. Each street is entitled to as much beautification as the home grounds themselves. The home seeker should feel a sort of pride in selecting his or her home on a street that is already beautified before their arrival. It is absolutely necessary that each street be planted to one kind of tree or palm throughout its entire length. Different streets may have a different variety, but a sense of unity should always be kept in mind, giving a restful and inviting appearance. There is no harmony in a confusion of many varieties of trees. If left to the party who will eventually occupy the house on any lot, there will not be uniformity; this must be done before-hand by the developer.

The question naturally arises, does it pay the developer to put in these additional improvements. Yes, it does. For, although he may be required to spend more in the beginning, he can (and as a rule a reasonable purchasing party, who after all is the one paying for it, is willing to have the improvement) simply pro rate the cost and add it to the sale value of the lot. Furthermore, a subdivision highly developed in this manner will in nearly every case bring a larger and more satisfactory profit to the developer. Another important feature is that if properly managed the entire subdivision can be cared for permanently by the developer by requiring a small fee of each lot owner to keep the property as a whole in an attractive and healthy condition.

The time is past when you can hope to sell home lots with nothing on them except a painted stake showing the lot number. The modern subdivisions that are going to be worth while in the future are those that have been intelligently planned, and where streets, parks and building lots are beautified by the liberal and intelligent use of plants, palms and shade trees. 


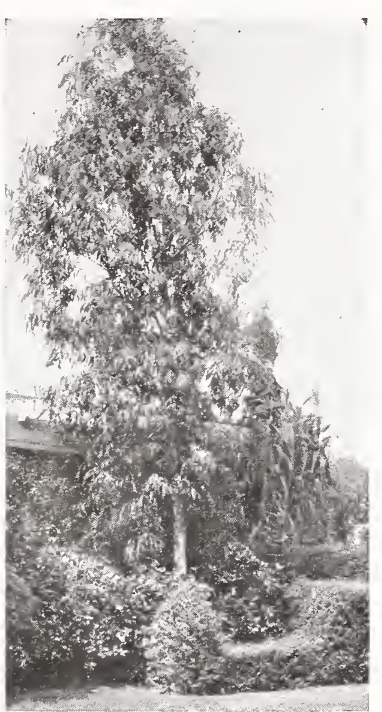

\section{Prepare a Plan}

S THERE are so many difficulties to overcome in the A proper laying out of any grounds regardless of size, we recommend a plan be prepared. With a plan to follow you will be able to eventually give your grounds a finished effect. The plan will enable you to carry out as much, or as little, of the work as desired in the beginning, gradually adding from time to time until eventually you get a well balanced planting.

Look Over Your Grounds. If interested in securing a better arrangement of your home grounds, make up a rough sketch as shown on this page and we will immediately instruct our architect to draw up a plan to fit your surroundings.

First get dimensions of house, garage and other buildings. Then measure length of your lot, distance from property Eucalyptus, Three Years' Growth. line to back and side of house, and width of the lot. Locate such trees and other permanent plants or structures, draw in walks and drives and give widths. Make a rough penciled sketch as you go and write the measurements in clear figures. Inside the house, write $W$ for windows and $\mathrm{D}$ for doors. Then draw an arrow pointing north and drawing is complete. Send with it snap shot pictures if convenient, showing front, back and side views of house.

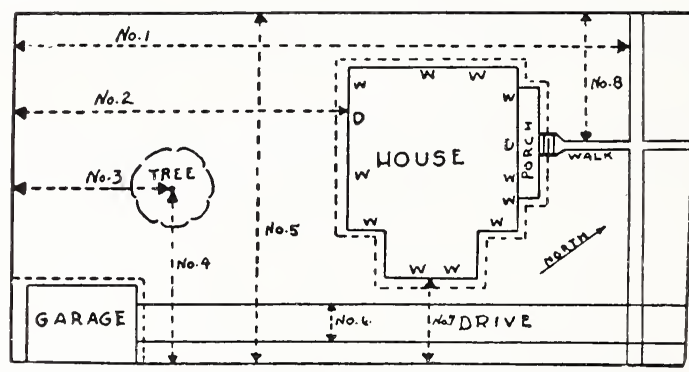

A Simple Method of Measuring Your Grounds for Complete Plan.

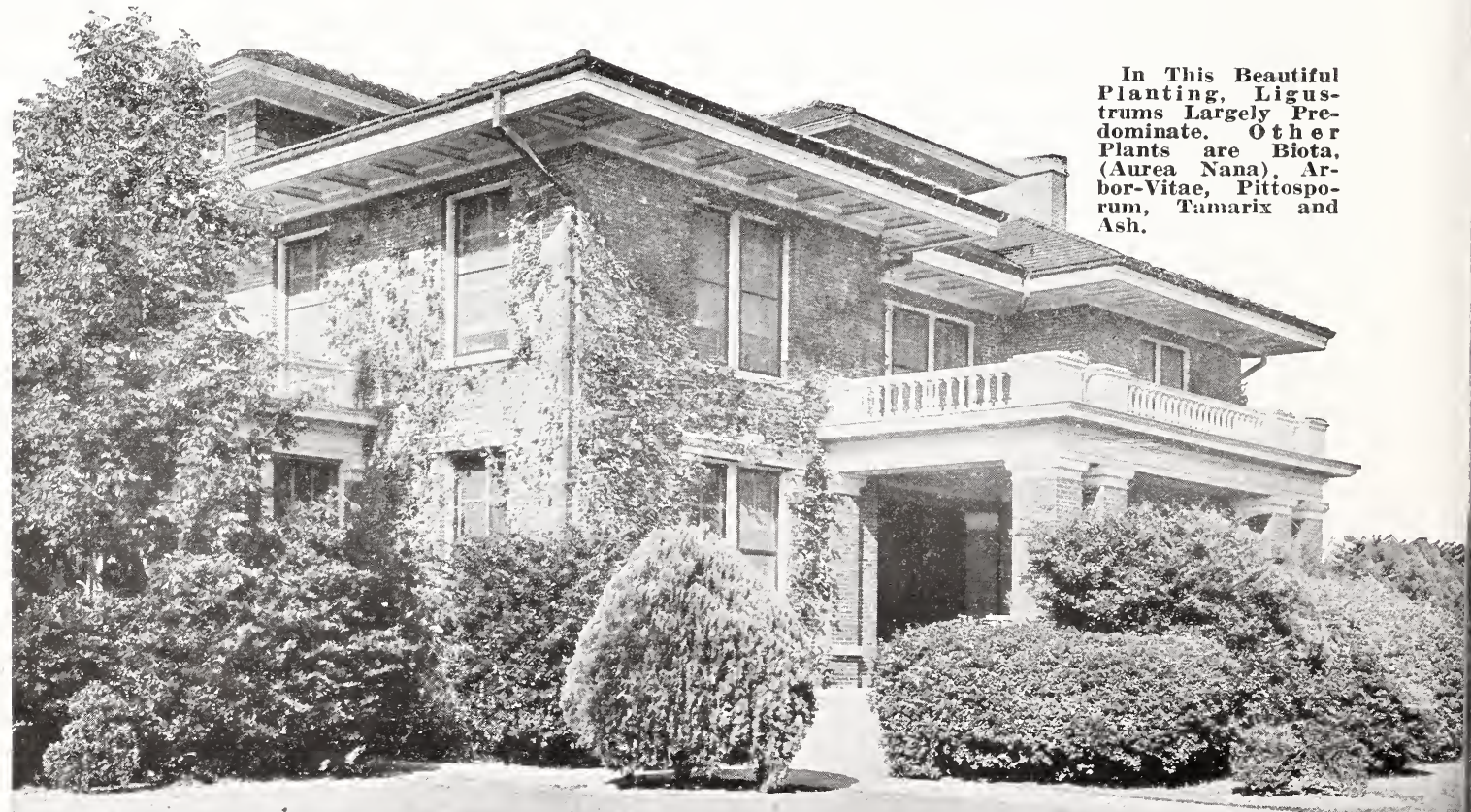




\section{Our Reason for Doing This}

You may wonder why we give all this service free. We offer it because it simplifies the handling of the order: makes ordering easy for the customer, and enables us to handle a large volume of business with less overhead expense, and gives our customers a free service never before attempted by any Nursery in the South.

While it may be true that we will not book all orders for which we draw sketches, it is reasonable to presume that very few people will take the trouble to ask us to give this service unless they are sincere and fully intend to do the proposed planting.

\section{Large Places and Estates}

Our plan service is offered to all home owners whose lots are the usual size with a frontage up to about 50 feet. Larger lots and big country places should have personal attention. For such places special arrangements will be necessary and advisable, and our landscape department is

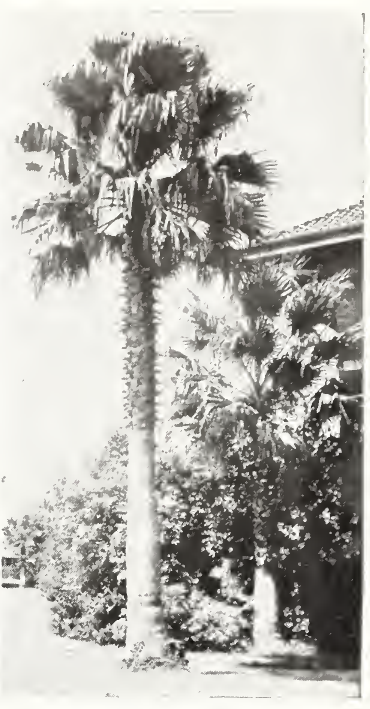

Washingtonia Palms. prepared to render such service at moderate cost.

\section{We Offer Our Service Free}

This is where our Plan Service can assist you to make the right selections and on an economical basis-you paying only for the trees and plants you decide to useand in most cases we will have various sizes to offer so that you may have large or small plants to suit your purse.

\section{Send Plans in Early}

This allows a better chance for attention to your plan.

Don't Delay Your Good Intentions. Many times we are anxious to improve our grounds with ornamental shrubs and plants, only to postpone, with the result that same is overlooked entirely. Today go out and look over your grounds and see if they are what you desire them to be. Send in your rough sketch and leave the rest to us.

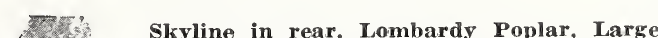
Skyline in rear, Lombardy Poplar, Large
Broad-leaf Fvergreens, Ligustrum Japonicum Note Large Open Lawn Space with Clear outlook from House.

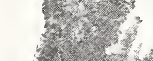
है
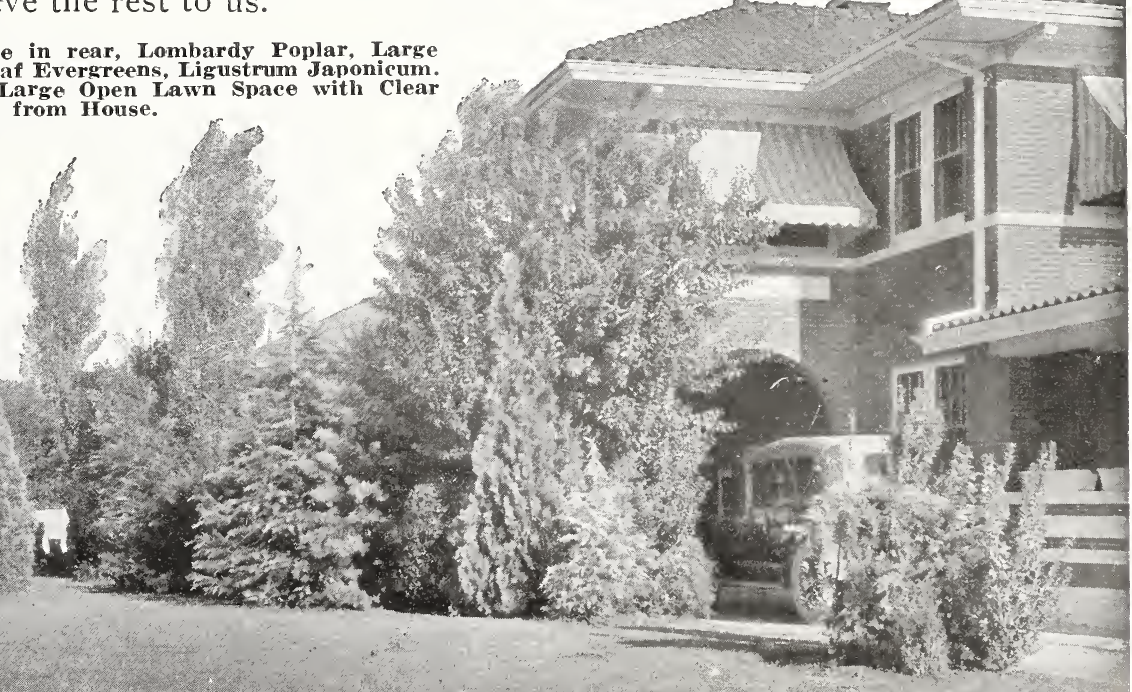


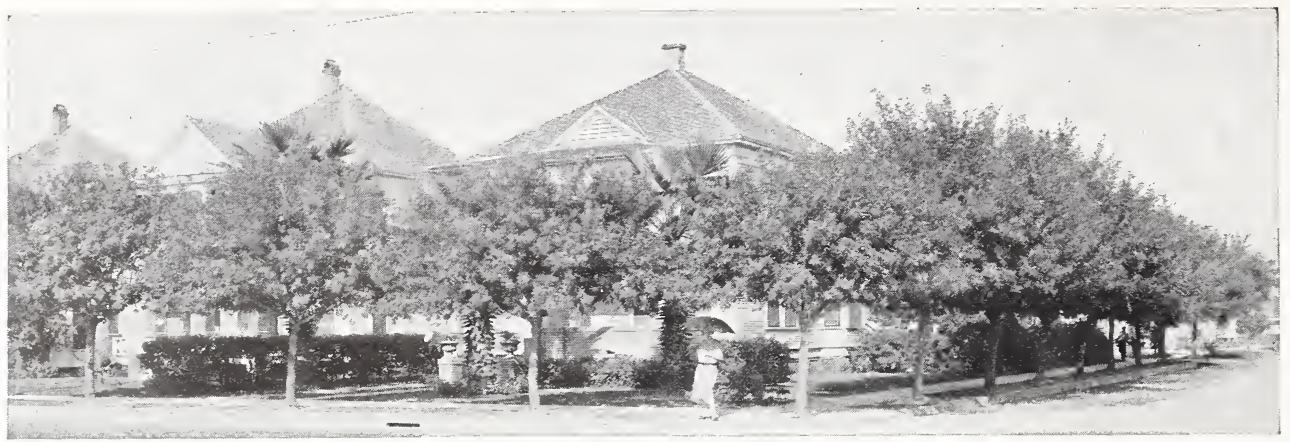

Rio Grande Ash as Shade Trees in a Coast City. "Our Planting."

\section{City, Town or Park Development}

TOO MANY of our southern cities and towns are almost devoid of natural beauI ty. Every village or city should have a sense of civic pride sufficient to arouse its citizens to the importance of preserving or adding to its beauty. It not only en-

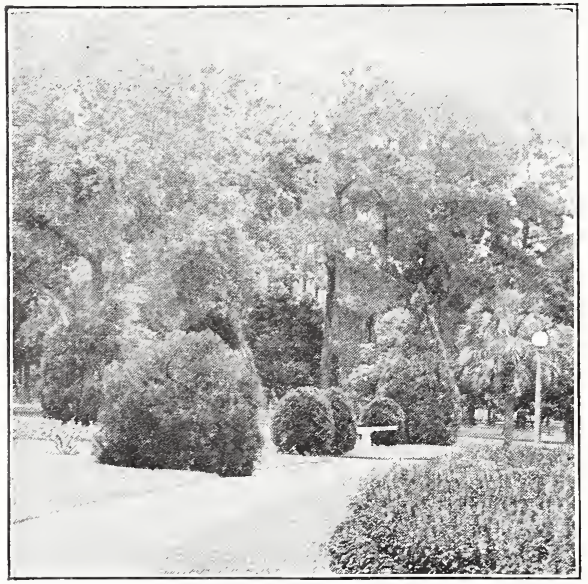

Conifers and Palms. ables us to get a little more joy out of the community in which we live, but it has a tremendous impression on the thousands of visitors passing through each year.

The first thought is to provide shade trees: and as their need will be continuous, one would naturally suggest the use of long-lived trees; but where the immediate need is great, there is also another side to the question. A shortlived tree grows quickly, coming into early usefulness and serves its purpose in a very few years. A long-lived tree usually grows more slowly but it serves its purpose for many more years, so in many cases it is advisable to use both classes of trees in such a way that the longer lived trees will become useful by the time the shorter lived trees reach their maturity, when they should be removed, leaving the space for further growth of the longer lived trees which should be chiefly of the evergreen class.

Use plenty of Palms. No other tree or plant gives such tropical effect and elegant display as Palms. We highly recommend both Phoenix and Washingtonia for city and park development.

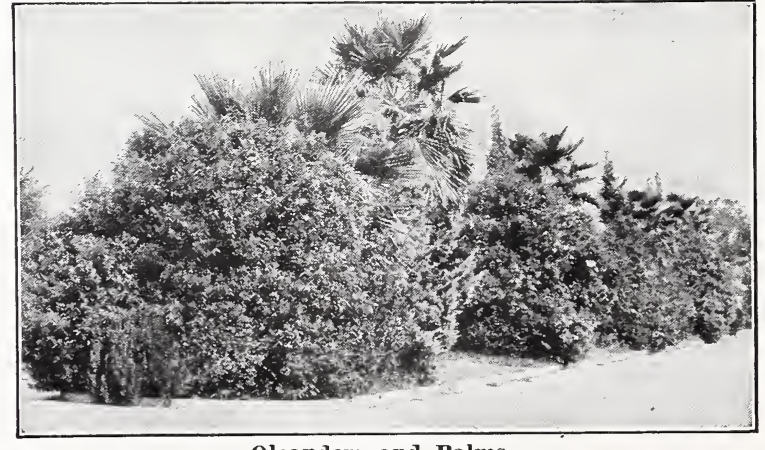

Oleanders and Palms. 


\section{Street and Avenue Planting}

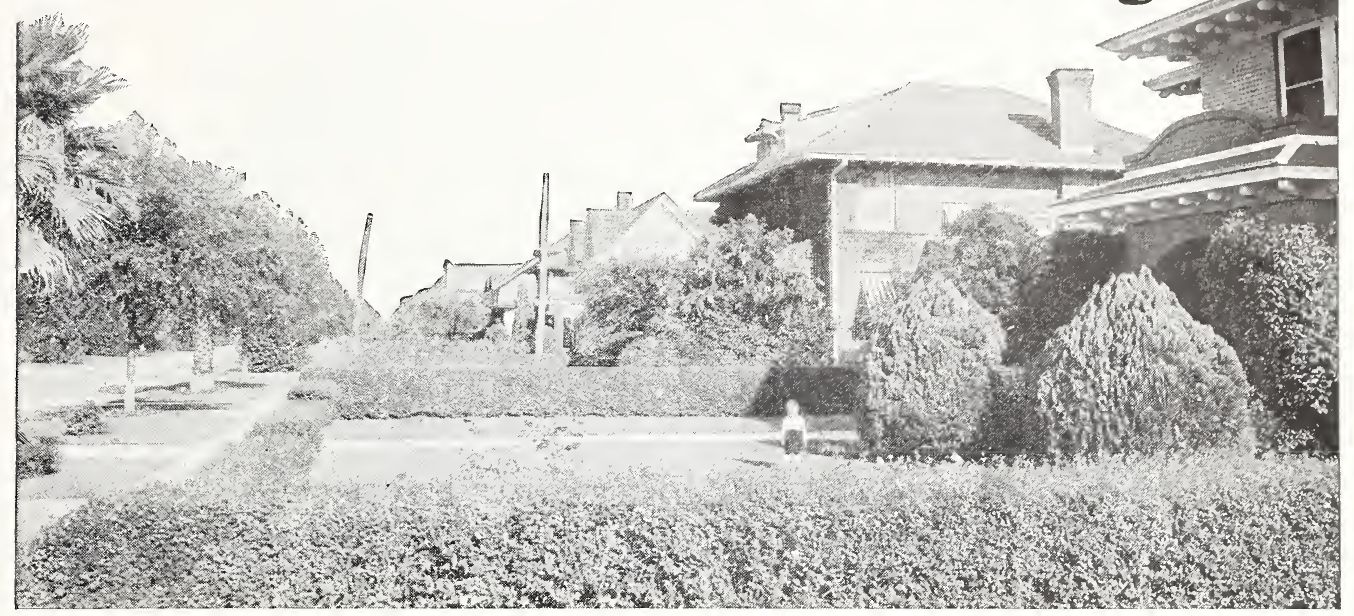

Q TREET planting should be uniform in kinds and varieties of trees planted, no two $\$$ kinds of shade trees being used on one street. On narrow streets with buildingsclose to property lines, the taller and more compact growing trees, such as Washingtonia Palms, Eucalyptus, Ligustrum Japonicum, Red Cedar, Southern or Rio Grande Ash, Dogwood, Tallow, and Soap trees should be selected; while on the wider streets the trees of more spreading growth, such as Oaks, Magnolias, Maples, Pecans and Sycamores, may be used more advantageously. Along residence streets where buildings are set close to the pavement, medium size trees with broad spreading tops, such as Camphor, Cherry Laurel, Dogwood, are most excellent. Palms make very attractive street

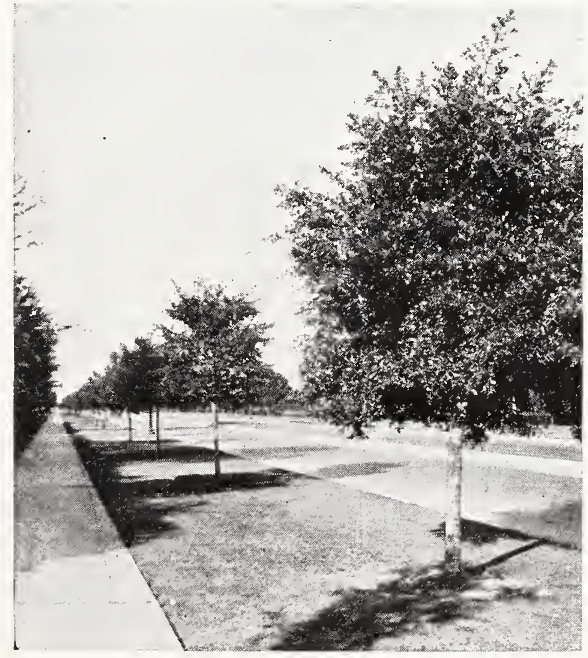

Live Oaks, for Streets That are Wide.

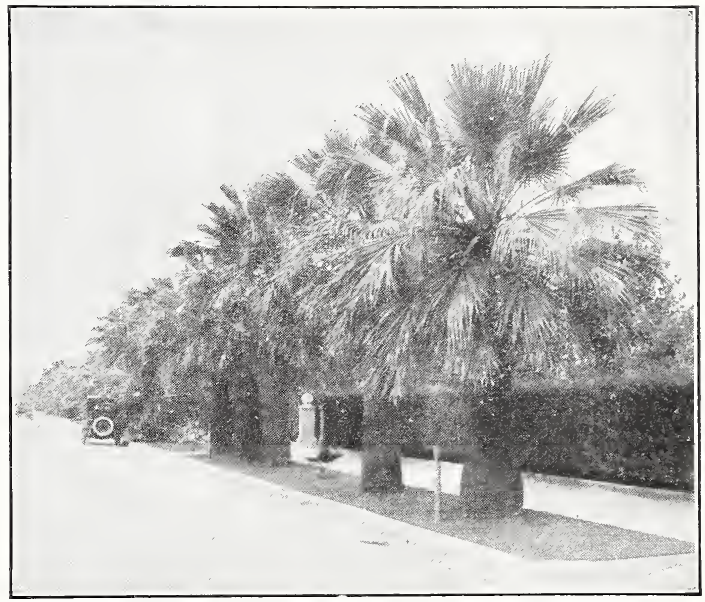

Washingtonia Robusta Palms for Narrow Spaces.

plantings, especially where buildings are close to the sidewalks or pavement, or where shade is not an important factor.

They add a peculiar tropical charm to our southern villages and cities, and especially to our visitors from the snowy North, and should be more seriously considered when planting. Trees should be planted about half way between the sidewalk and curb-line, leaving sufficient space between trees to allow for normal growth and development.

Pecans are among the most desirable for avenue planting or for rear of town or city lots, being as ornamental as any tree that grows, and their annual yield of the best of all nuts makes them more interesting yet. 


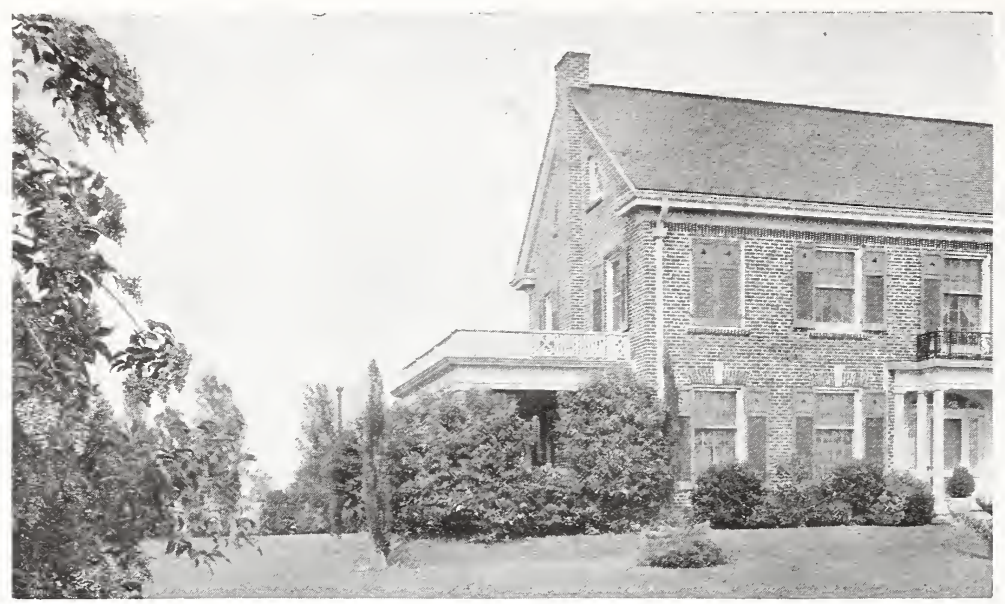
Tall Type of Ligustrum at Corners. Wax Ligustrum and Pittosporum in

\section{The Importance of a Complete Planting}

W E WISH to emphasize the value of having a complete planting done wherever it is possible. Every home dweller has the right to plant what he chooses, yet from our long experience in beautifying homes we have found it pays to set all stock as near one time as is convenient. Rather than write us for individual prices on plants, just send us a list of the plants you love best together with an outline of your buildings and grounds, and we will thoroughly examine same and offer you our suggestions. Our service includes not only the supplying of the plants selected but in addition the preparation of plans, specifications and even the laying out and planting of entire work. Ask for full details concerning plans and cost for Professional Services.

\section{Our Service Plan}

With the facilities we have at our command we are safe in stating we can handle your work in a way that will assure satisfying results. You can rely on our service, as we have experienced men in all departments. Professional

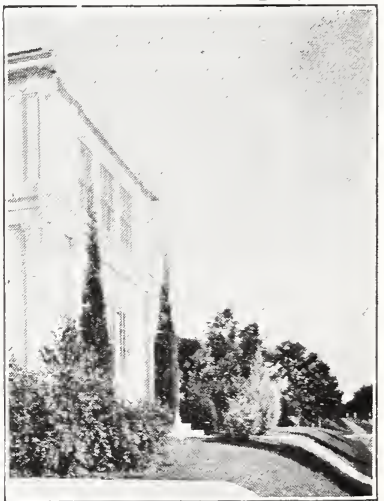

Correct Usage of Tall Conifers. charges for plans and consultation are subject to the extent of improvements to be carried out, covering time consumed in traveling, consultation, inspection, preparation of plans and specifications. After inspection is made an estimate of the cost of entire work will be submitted.

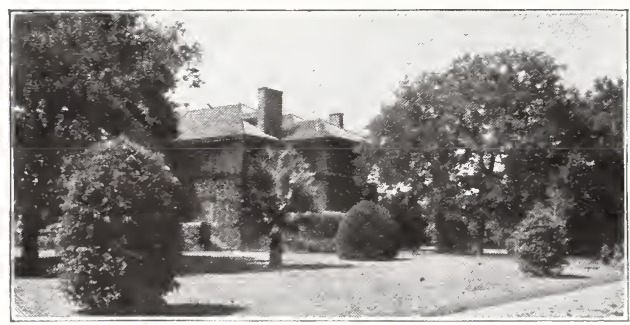

Trees Should be in Every Yard. The Bushes are Camphors-The Sheared Specimen, a Wax
If you do not desire a detailed plan and you only care to do a limited planting, we will be glad to send you an estimate covering cost of plants desired. In such cases we encourage customers to just send us a rough sketch of grounds (see page 6) and we will make a selection for you; there will be no charge for this service. However, where property conditions warrant, we advocate following architect's plan. 


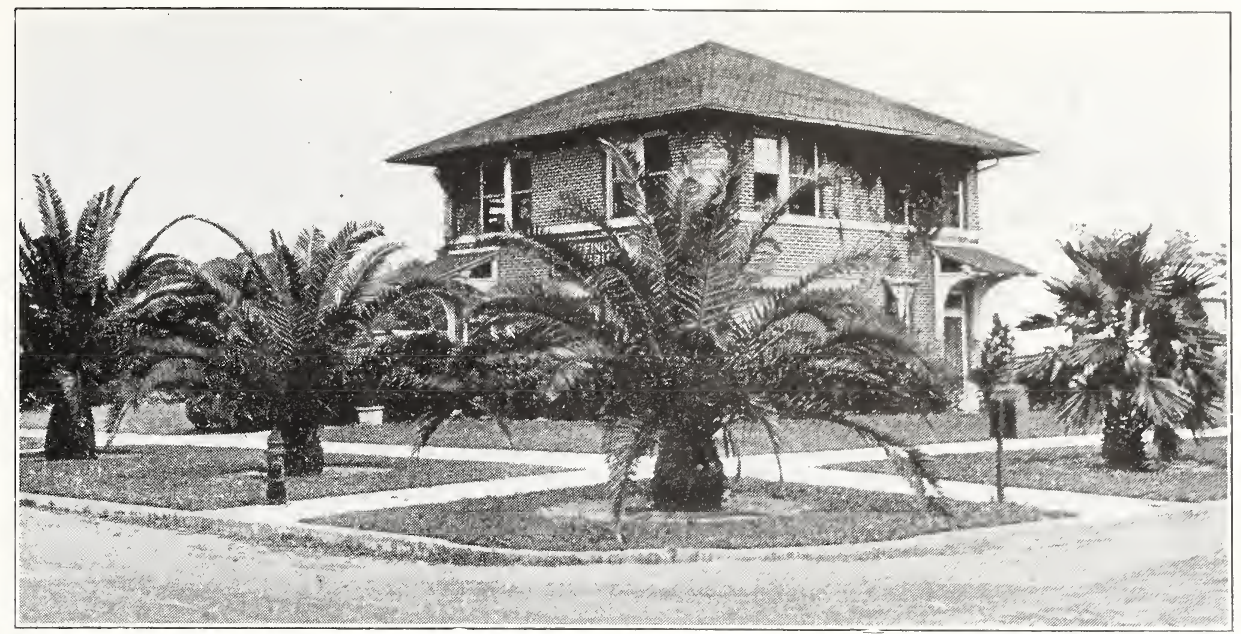

The Jacksonville Office, Greenhouses and Grounds.

\section{Our History}

NEARLY 40 years have passed since the present Griffing organization had their first inception in a small nursery plant in northern Florida on land owned by Father D. C. Griffing and managed by his five sons under the name of Griffing Brothers. So successful were their efforts under the Griffing policies then adopted and since followed religiously, that their operations rapidly extended westward to the Rio Grande. Always the Griffings grew the stock they sold, offered the best of everything, experimented in every locality to find the most adaptable varieties, dug their trees with care, packed under rigid inspection, and in all their activities gathered and disseminated information for the benefit of their patrons.

Several years ago, State Nursery Inspection Regulations interrupted exchange of stock between branches, making it practically impossible for the extensive organization to continue under one management and made each branch an individual concern, automatically liquidating Griffing Brothers, and so was the beginning of the present nursery organization which continues to serve you. The Texas properties were taken over by Mr. W. C. Gritting who is now the owner of the business known as "Griffing Nurseries" and operated under that name. The Florida properties known as the "Griffing Interstate Nurseries," owned by C. M. Griffing and Co., Inc., is directed by Mr. W. D. Griffing.

This brief history is given to offer you assurance that your orders will have the personal attention of an organization of experienced workers gathered together in the various departments by a man who has devoted a life time to the development of perfect service, in supplying your nursery wants.

\section{Our General Catalog Circulates All Over The Southland}

Think of the many thousand others who will see it through borrow ing and other ways. Then picture the magnitude of the business we are prepared to handle. Hundreds of thousands of trees and plants in many varieties and kinds. Is it any wonder that we can offer higher quality of plants, better values, and more efficient service than a smaller organization?

\section{Why Our Service is Best}

In our immense concern it is possible for men to specialize and find the position for which they are best suited by nature and training and there they are much better equipped to serve than in a

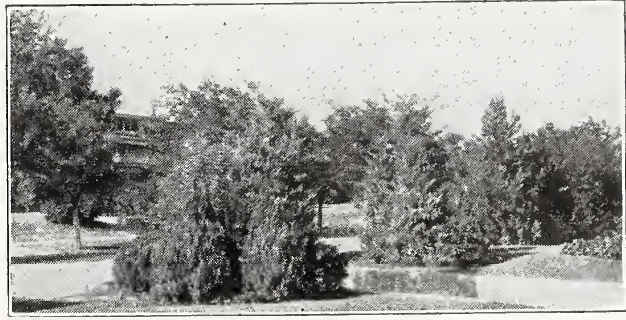

Landscape Groups-Conifers Predominating.

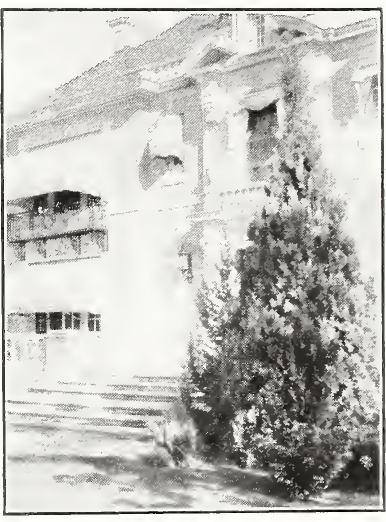

Illustrating the Importance of Large plants in Your Planting. smaller business where varied duties must fall to each.

\section{Why Our Prices Are Low}

With so many friends it is to our financial interest to maintain our record of nearly forty years and realizing this we are constantly alert to guard against errors and dissatisfaction from any source. If you multiply our volume of business by the years we have been in operation you can see the tremendous experience back of us. You gain by sending your orders to the largest concern for we can affor less profit, giving you the difference in lower prices and better plants. 


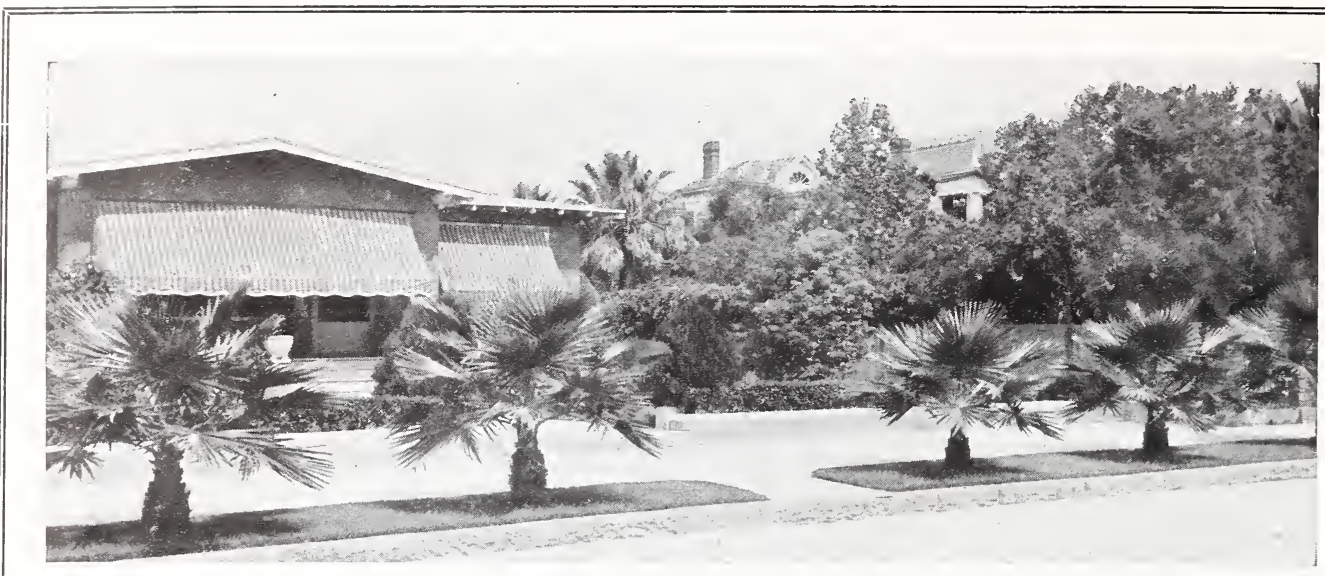

Washingtonia Palms, Best for Street Planting for 150 to 200 Miles from the Guif or South Atlantic.

\section{This Catalog Our Leading Salesman}

You Pay No Agents' Commissions When You Order Direct From Us.

All Your Money Goes for Plants. Think This Over.

The pride of any town or city is its beautiful yards. The interior of the houses cannot be seen by every visitor and it is by the exterior that they must judge. Make your home the pride of the family and of the neighborhood. A few of our evergreens, some of the flowering shrubs, a tree or two and a few cents worth of flower seed will make all the difference in the world. The cost is negligible and the effect is marvelous. You will be justly proud of your work.

\section{PLANTING MAKES YOUR HOME WORTH MORE}

Beautiful shrubbery, trees and flowers make your home more desirable and increase its value. Real estate men realize this and in the larger towns and cities have planting done before they offer a home for sale. A few fruit trees, some grape vines and berry bushes will give you delicious fruits at all seasons and the cost for trees and plants is less than the value of the ripe fruit gathered from the first crop.

\section{AN ORCHARD FOR PROFIT}

Commercial orchards pay large profits from small acreage and even the small home orchard will supply sufficient fresh fruit for the family, ample for canning and preserving, with a surplus for the local market. You have bought fresh fruit and know the prices you paid. Why not save this expense and make the profit by having an assortment of trees in your own back yard? We list only the best varieties that have been tried and tested and have proved their worth. You can't go wrong ordering from us.

\section{FREE SERVICE DEPARTMENT}

Filling a Need of Plant Lovers

That is what we believe we are doing with our Service Department when we gather and disseminate information dealing with fruits, orchards, ornamental trees, and shrubs, landscape planting, shade trees, vines and those many beautiful and valuable plants which are

adapted to the southern section of our country. Few nurserymen, florists, or landscape men are equipped and experienced to do this-the more need for us with 35 years experience in propagating and growing plants together with planting landscape projects and orchards to offer information gained in no way except by experience and practice combined with accurate technical knowledge.

\section{FREE BULLETINS ABOUT PLANTS}

To help you grow your fruits and ornamental plants successfully we have published a set of bulletins on various subjects and with one of these as a guide you can have excellent results although your experience is negligible. Write for the ones in which you are interested. They are free and we want you to have them. The list now ready for distribution follows:

Griffing's Service Bulletin No. 71, “General Fruits"Peaches, Plums, Pears, Persimmons, Grapes, etc. Treating on Variety, Adaptability, Cultivation, Fertiliz ng, spraying and Marketing.

Griffing"s Service Bulletin No. 66, "The Pecan"-Its Economical Value for every farm and home, and as a Commercial Money Crop.

Grifting's Service Bulletin No. 76, "The Fig"-As a Home Fruit and as a Staple Commercial Crop.

Griffing's Service Bulletin No. 56, "Shade and Ornamental, Trees, Shrubs, Roses and Landscaping the Home."-Suitable Trees, Shrubs and Flowers, and Their Proper Arrangement and Care.

\section{Your Attention is Directed to Our Special} LANDSCAPE SERVICE

And Department of Landscape Design.

We offer the most complete Landscape Service, including preparation of plans, supplying of plant material, and when desired additional service of planting or superintending can be had. If you want the highest class service in the most economical way, don't fail to write us about your plans. We plan any grounds, large or small. Corps of experts in this department.

\section{THESE PEOPLE NEED OUR SERVICE}

Home Owners

Civic Clubs

School Boards

Real Estate Dealers

County Agents

Factory Owners

Ladies' Clubs

\author{
School Superintendents \\ City Officials \\ Park Commissioners \\ Cemetery Officials \\ Chambers of Commerce \\ Landscape Architects
}




\section{Nut and Fruit Trees}

While we have greatly extended our business in Ornamentals and Roses during recent years, we have by no means neglected the great commercial lines of Horticulture so important to the South. We are constantly building up and increasing the production of Pecan trees, Fruit trees, Grapes and Small Fruits, for we find as those planted a few years ago come into bearing in all parts of the South, it is most impossible to keep up with the demand. So while we love the Ornamental side of the business, we have no inclination or could not afford to neglect the Fruits and Nuts.

\section{ORCHARDS}

The land that will produce the best farm crops will also produce the best orchards. Rolling, well-drained lands are best for all varieties of trees. Therefore, we urge that you do not plant our good trees on land too poor for other plantings.

\section{ARRANGEMENTS OF PLANTINGS}

Proper distance, that is, in allowing each tree plenty of room for spreading. Longer-lived and larger trees should be planted at a greater distance apart; the shorter-lived trees can be interplanted to a very good advantage.

If you wish information about Time to Plant, Preparation of the Land, Distance Apart, Cultivation, Fertilizers and Spraying for the Control of Insects and Diseases, ask for our General Fruits Bulletin No. 71.

\section{Griffing's Paper Shell Pecans}

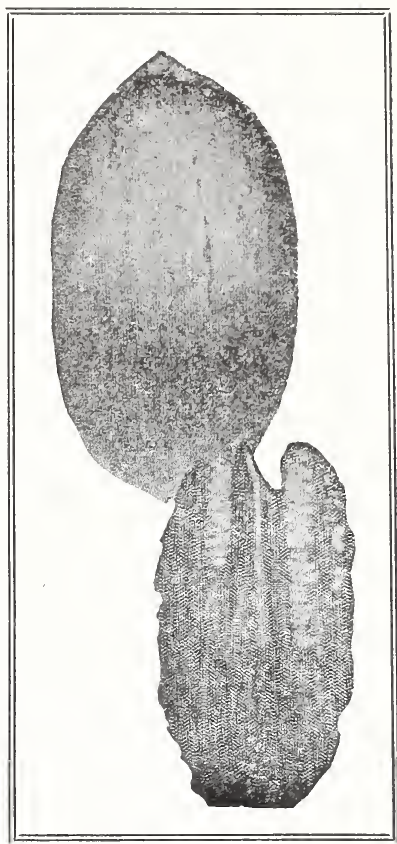

Pecans are the Highest Quality and Highest Priced Nuts in the World.

The improved Paper Shell Pecan nuts hold first place and command the highest price of all the world's nuts. Pecan nuts are in demand constantly at good prices for culinary purposes and for the making of candies, etc. Nuts are gradually taking the place of meats in the staple daily diet of the world's people. In this the Pecan will assume first place, because it is the richest in nutriment of all the nuts.

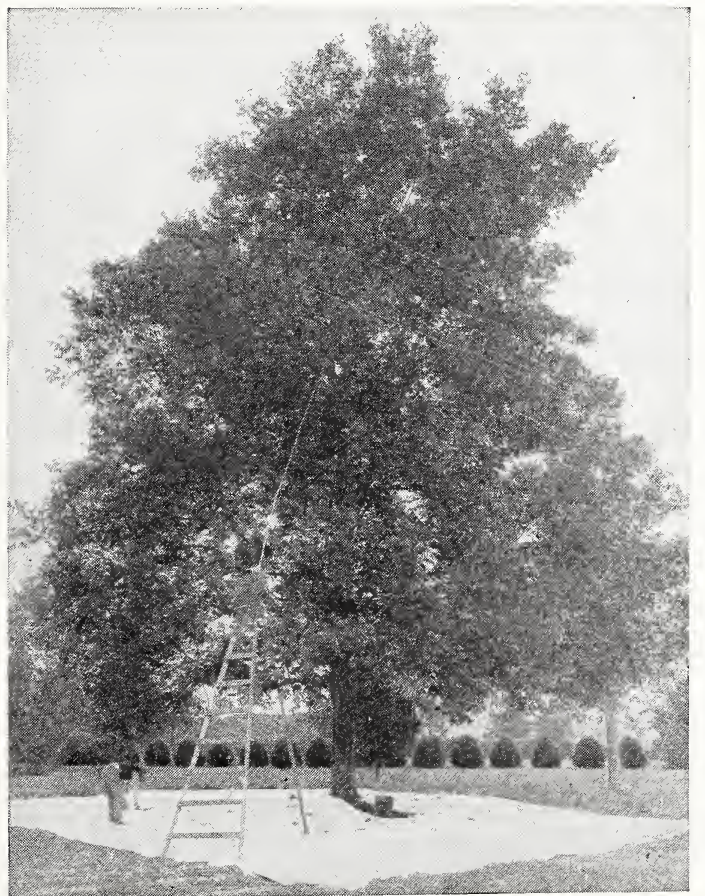

Harvesting Pecans.
The Kind of Pecans We Offer You

We have been closely identified with the development of the Improved Paper Shell Pecan industry since its first inception, and have originated, introduced and disseminated several choice varieties. We are owners of some of the South's largest bearing and young Pecan groves.

\section{Utilize the Waste Space on the Farm}

Pecan trees of Improved Paper Shell varieties lanted along the roadsides, avenues, drives, fence lines and around barns and outbuildings will not only add a distinctiveness and character to your farm, but will in a few years yield a revenue in nuts sufficient to pay you.

All for the cost of a few trees and the keeping of the waste spaces cleaned and in order, as they should be on well kept farms. Pecans are a safe investment.

The growing of the improved varieties of Paper Shell Pecans has gradually developed until it has become one of the South's most important agricultural pursuits.

The Pecan is an Excellent Shade Tree

We are in position to offer some unusually fine trees in sizes 7 to 9 feet 9 to 12 feet, and 12 feet tres plantand up. They are ideal for yard and street plant ing. as well as producing the best nuts known today. offered.

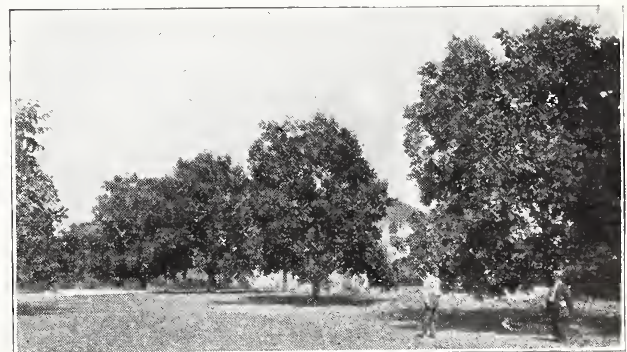

Twelve-year-old Pecan Trees from Griffing's. 


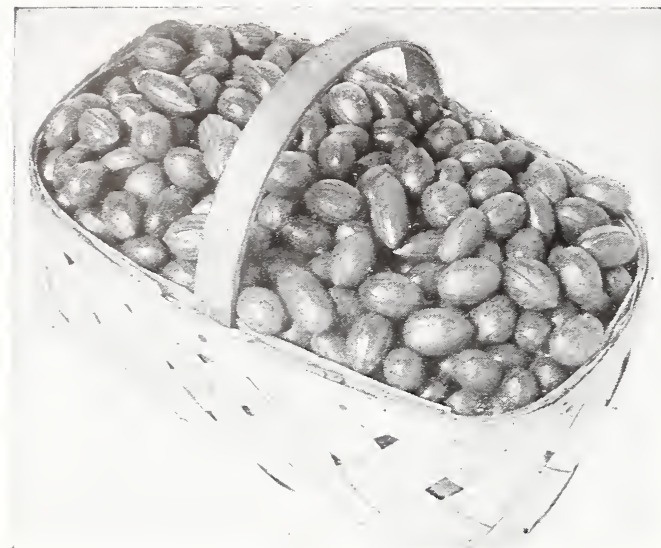

Basket of Pecans.

\section{How to Plant}

Trees should be planted at a distance of $45 \times 60$ feet apart, requiring 18 trees per acre. At this distance, other crops may be successfully and profitably cultivated between the rows of Pecans without detriment or injury to the trees. The cultivation of other crops while trees are young, actually benefits the Pecan trees and reduces the expense of upkeep to the minimum. We recommend the cultivation of corn, cotton and vegetable crops between the rows.

\section{FREE-SPECIAL BOOK ON PECANS- BULLETIY Yo, 66 .}

A special book of 32 pages devoted entirely to the growing and marketing of Pecans. We will be glad to send you this book free, if you are interested in Pecans.

BIG Z. The giant of all Pecan nuts; was introduced by us for the originator J. W. Zink, of Southern Mississippi. This variety bears very young, produces heavy clusters of nuts, 38 to 40 weighing a pound. The ideal variety for dooryards.

BRADLEY. Cracking quality excellent; kernels plump. Always takes first prize at fairs on account of richness of meat. Tree of limber growth, withstanding gales without shedding nuts or breaking limbs. Medium to large nuts.

CURTIS. Tree vigorous, Open growth. Bears at early age. Thin shell; cracking quality exceptionally early age. Thin shell; cracking quality exceptionally smaller than other varieties listed it makes up in guantity and in cracking tests.
FROTSCHFR, One of the best known varletles; remarkably thin shell; splendid cracking qualities; large size.

MONEYMAKER. It combines early maturity and heavy production.

NELSON. Very large, attractive nut, borne in clusters. Grood flavor.

PABST. Sturdy, thrifty grower; productive; nuts large; one of the best eating nuts.

PRESIDENT. The nut probably embraces more of the characteristics of a perfect nut than any other. Oblong, slightly compressed with a sharply pointed base; large size; texture fine.

SCHLEY. One of the best; kernel plump; superior in quality, richness, flavor.

STUART. A variety generally considered the standard by which other nuts are judged.

SUCCESS. Size very iarge; kernel usually plump; flavor good.

TECHE, Commences bearing very young: medium size; quality good; a profitable, practical variety.

VAN DEMAN. One of the most attractive in appearance. Very rich and well flavored. Medium to

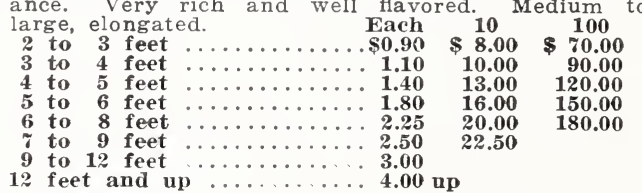

\section{Japanese Walnut}

This tree produces the very finest type of full, rich, meaty kerneis. Can be removed whole for candies and table delicacies. The only walnut which thrives in the South. A beautiful tree of great value for shade and ormament; a credit to any ground.

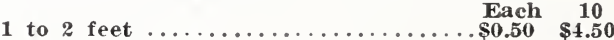

\section{Cultivate Well and Get Results}

We cannot too firmly advocate cultivation of Nut Trees. You are aware of the large income they will bring you. If you want the best results it is imperative that you cultivate your trees well and give them excellent care and attention. Without this proper attention it is impossible to expect good results. We know one large customer of ours who tells us that he neglected his trees for two years and then learned the proper care methods: trees that he planted later and did care for properly show very distinctly how it pays. Even his neglected trees are now making fine development with good attention.

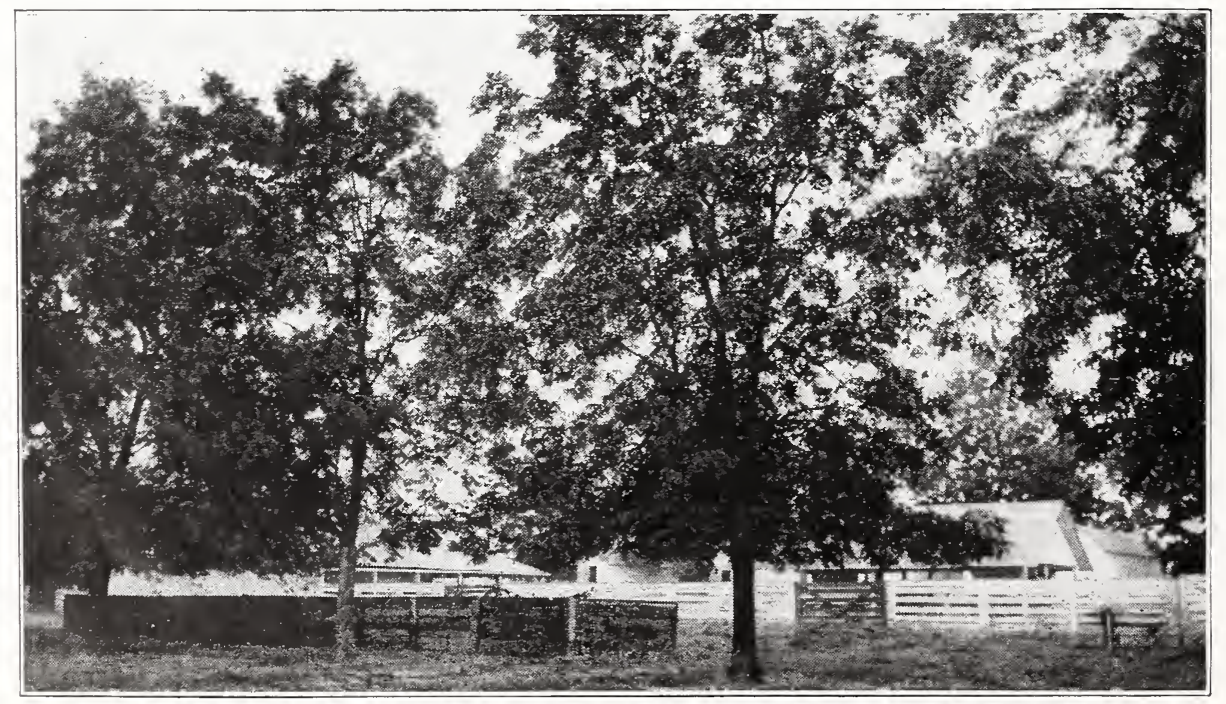

Pecans Producing Food and Affording shade in What is Usually Waste Space. 


\section{Japanese Persimmons}

Are destined to become one of the leading fruits of the Cotton Belt and lower South. This may seem an
extravagant statement, but as soon as there is enough of the fruit on the market for the people to learn the richness and deliciousness, the demand will increase far in excess of the supply. Where the Persimmon is known on the market, it finds ready sale. COSTATA. Medium sized, conical somewhat four sided; skin salmon-yellow; flesh light yellow, almost sided; skin salmon-yellow; flesh light yellow, almost DIA DIA MARU. Thrifty open-growth tree, distinct light foliage; fruit medium size, flat and four-sided. Flesh creamy white, fine quality.

FUYUGAKM. Of recent introduction from Japan. Tree vigorous, upright growth; fruit medium to large nearly round, but somewhat flattened; skin smooth tough; color reddish yellow; flesh meaty and of ex ceptionally good flavor. Bears young. Non-astrin gent; can be eaten while still hard; may be peeled and eaten like an apple.

GAILEY. The pollinating variety to be planted among other varieties; one to every seven or eight is recommended.

HACHEYA. Very large, oblong. Conical with rounded point. Reddish yellow. Trees vigorous and attractive. HYAKUME. Very large, roundish oblong, flattened at the ends; skin light, bluish yellow; flesh light brown meaty, not astringent even while hard.

OKAME. Large, usually oblate; dark red, attractive. Yellow flesh, few seeds. Vigorous, sturdy; lives to

TAMY old age. is large, somewhat flattened and with a compressed ring around it as though a string had been tied around the fruit while growing. Color beautiful golden red; skin quite thick and tough.

TANE NASHI. The best known and most popular variety; large, conical, pointed. Early bearer, early

TRIUMPM. Yellowish red, tomato-shaped, fine grained TRIUMPH. Yellowish red, tomato-shaped, fine grained TSURU. Long pointed variety. Bright red, flesh orange color with darker coloring near seed. Proorange color with darker coloring near seed. ProYEDDO-ICHI. Roundish oblate, size large, color dark red; flesh dark brown, almost purple around dark red; flesh dark brown. almost purple around the seed.

YEMON. Large, tomato shape; somewhat four-sided; flesh yellowish; generally seedless.

ZENGI. Medium size, but one of the most valuable and ieliable. Tree sturdy, long lived and very prolific.

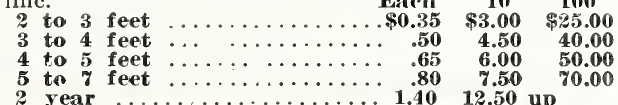

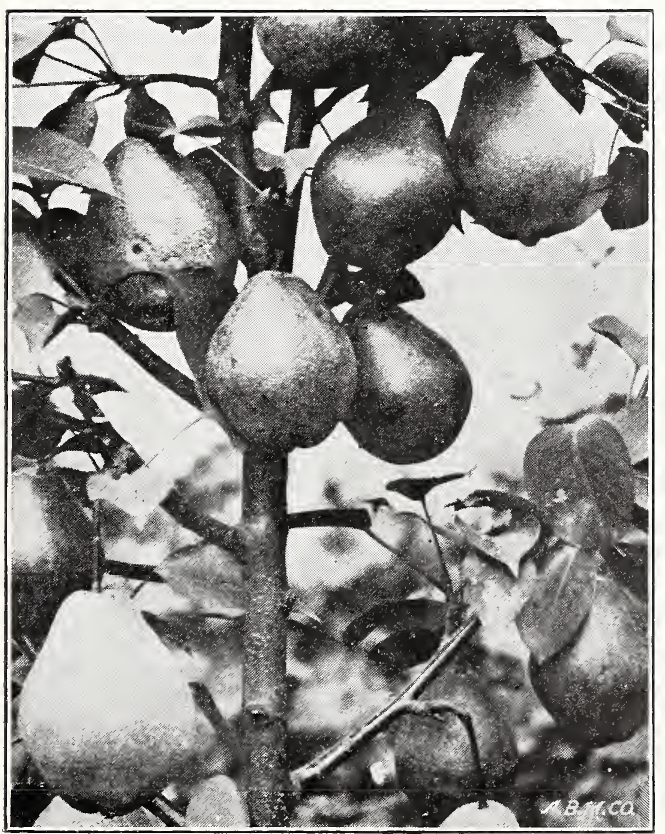

Pineapple (Sand) Pears.

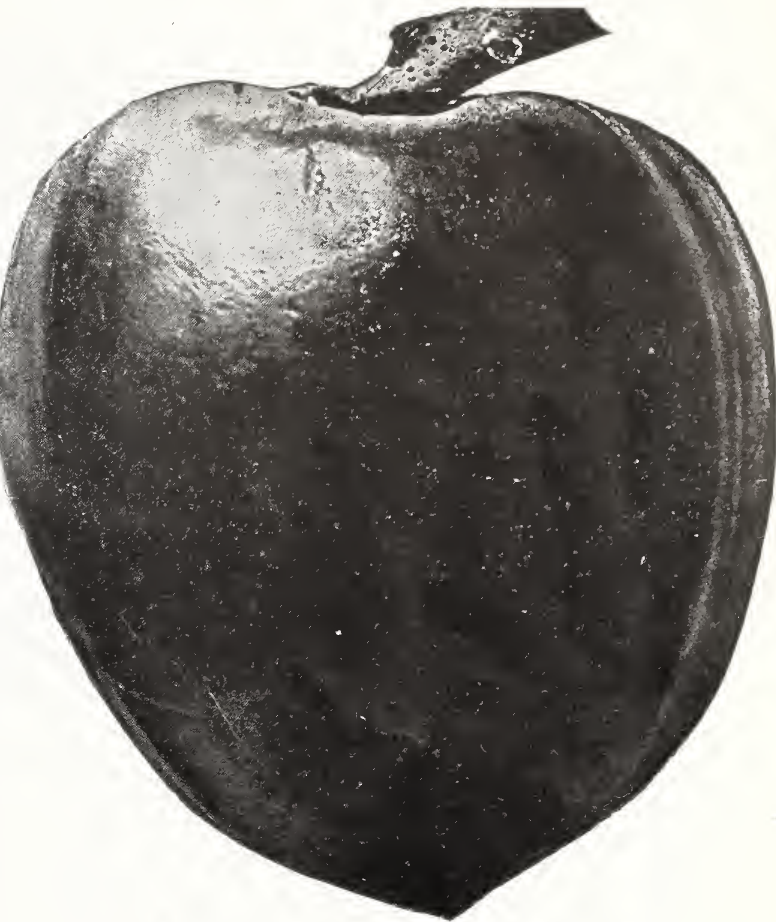

Tane Nashi Persimmon. Lealing Market Variety.

\section{Pears}

The Pear is desirable and tinds its greatest market value for canning and preserving. The Pear is the most economical of ali fruits that can be grown for should have a few Year trees and every farm a Pear orchard.

Our list of Pears is selected with special view to their adaptability to the lower South.

CINCINCIS. Thrifty grower, early, prolific bearer. clusters. August and September Adapted to all sections of the South.

GARBER. Rapid grower, good quality. Ripens in September.

KIEFFER. Large. The business Pear in many parts

of the South. Late.

\section{Blight Proof Pears}

Because of blight, the list of adapted Pears for the South is limited. Ours are from "Blight Proof" strains and are highly resistant to this disease, some being absolutely blight proof. A few trees will add considerably to your income.

DIXIE. A new variety originated in Southern Georgia. trees have always been absolutely free from blight.

PINEAPPLE (Sand). Name adopted by American Pomological Society. An excellent preserving or canning Pear. When cooked, holds its white color, not turning brown like most varieties of Pears. As an eating Pear it is fine when fruit is picked when nearly fully grown and ripened in a cool, dark place: is an absolutely certain shipper. Blight proof.

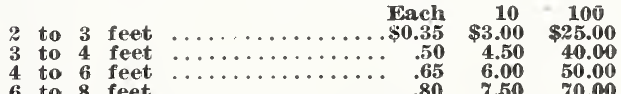

6 to 8 feet $\cdots \cdots \cdots \cdots \cdots \cdots \cdots$

\section{OUR STOCK IN NORTH CAROLINA.}

Charlotte, N. C.

I like to do business with people like you, as my orders are always given such prompt attentlon
and everything shows up nicely. 


\section{Peaches}

The Greatest Money Fruit Crop of the South

Every Southern state now has its commercial Peach growing industries in localities where enterprising citizens have demonstrated that by planting on well drained, natural forest lands and caring for their orchards according to approved methods there are greater profits to be made than in takings involving such small investments.

Peaches are adapted to the whole south, but not the same classes or varieties to all sections.

Peach trees may be kept healthy an free from ravages of insects and disease by inexpensive modern methods, so that every family with even ods, so that every family with even soil can raise and enjoy this most

Griffing's Service Bulletin No. 71 , on General Fruits, treating extensively of Peach culture for the South, is invaluable for amateur fruit growers. classes and varieties adapted to the various sections of the South are correctly defined. The successful modern methods of fertilizing and controlling methods of fertilizing and controlling means are duly described. This Service Bulletin free to all customers.

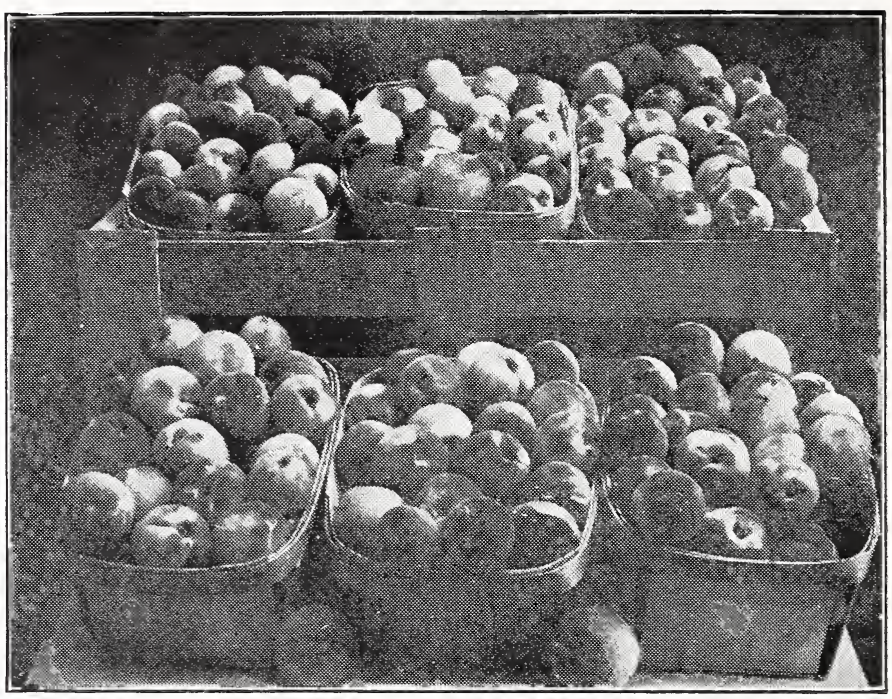

Jewell Peaches, Florida's Moneymaker.

\section{GreatSouthern Peach Belt Varieties}

ARP BEAUTY. Medium, oblong, yellow, blush tint. Flesh yellow, good quality. Freestone. Good commercial Peach, Ripe June 1st to 10 th.

BELLE OF GEORGIA. Large, showy, clear creamywhite, tinted red. Flesh white and firm, excellent quality. Freestone. July 1 st to 15 th.

CARMAN. Large, creamy-white, tinged red. Freestone. June 20 th.

CHINESE CLING. Very large, white tinted red. July 15 th.

ELBERTA. Large, rich yellow, red cheeks. July. GENERAL LEE. Large, white with slight blush, quality good, splendid bearer. Cling. July 10 th to 20 th.

HLEY. Large, red cheels, flesh white, red at pit. Freestone. June 20 th.

HEATH CLING. White with red tinge, flesh white. Cling. August.

J. H. HALE. Size large, flesh yellow, firm. Ripens a few days before Elberta. Freestone.

MAMIE ROSS. Large, flesh white. Cling. June 1st. MAYFLOWER. Large, highly colored. Semi-cling. Very early.

NIX'S LATE. White, highly fiavored. Cling. September.

SLAPPEY. Large, deep yellow. Early July.

WADDELL. Rich, creamy-white. Juicy, sweet. Freestone. Early'June.

Prices of Peaches on Peach Root.

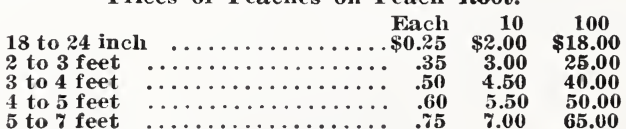

\section{PEACHES OY PLUM ROOTS}

Some people recommend the planting of Peaches grown on plum roots for the coast country as they are not affected by the Nematode (the insect that causes root-knot disease, the direct cause of short life of this class of trees), and plum roots will also thrive and give good results on land so wet that peach roots will not grow at all.

To meet this demand, we have grafted a large stock of all leading varieties on Marianna Plum Roots We recommend that this class of trees be planted deep enough so there will be three or four inches of soil above the union of the graft and plum root, and believe by this method Peaches can be grown in believe by this method Peaches can be grown in many places wher the on account wet for peach roots.

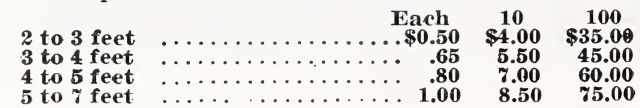




\section{Plums}

Recent crops of Plums in Florida and the lower South have convinced thousands of people that there is no better section for their extensive culture. Southern markets and homes were abundantly supplied with this most delicious fruit during the months of May and June, while the few that found their way to the northern markets met with no competition and brought most satisfactory returns.

We recommend more extensive planting of Plum rees. They should be grown in quantities for refrig plutor car shipments and we believe a commercia plum orchard onfers today one of the greatest inducements to the man who wants to engage in a pleasant and highly proftable horticultural pursuit. The Plum is a lruit that is easy to grow, bears young, crops preserving as well as marketing in a fresh state.

\section{PLANT PLUMS IN POULTRY YARD.}

The clean packed ground and high percentage of nitrogen in the chicken manure seem to be just what shade during summer and admit sunlight during shade

ABUNDANCE. Medium to large, round pointed; subacid. Rich and good.

BURBANK. Very large, clear rich red, showing yellow dots. Flesh deep yellow, firm and meaty.

EXCELSIOR. Remarkably strong growth, fruit medium to large size; reddish purple; flesh firm, yellowish. A most valuable southern Plum.

FLORIDA. A new Plum of the Japanese strain. Very large, abundant bearer. Reddish yellow; no
Plum has ever been more promising. Ripe in May.

GONZALES. Very large, red, good shipper, fine quality. Originated in South Texas. June.

HAPPINESS. Very large, glowing red; flesh firm, rich, juicy. June 10.

HOYT. Bears in long clusters. Medium to large; purplish red. Meat dark yellow, pit small.

KELSEY. The largest Plum grown, heart-shaped; greenish-yellow, splotched with reddish-purple. July.

ICCARTNEY. Very early, oblong, transparent yellow; strong grower; productive. Very early.

RED JUNE. Vigorous grower. Prolific. Medium to lemon yellow, slightly sub-acid. June.

STUMP OR HOWE. Medium large, dark rich red. Ripe in May.

TERRELL. Large, nearly round, reddish yellow, wine-red when fully ripe. Very fine quality. June 1st.

WICKsON. Large, deep maroon-red. Flesh firm; deep amber-yellow, small pit. Ripe in July.

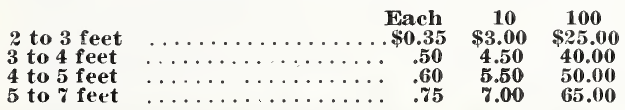

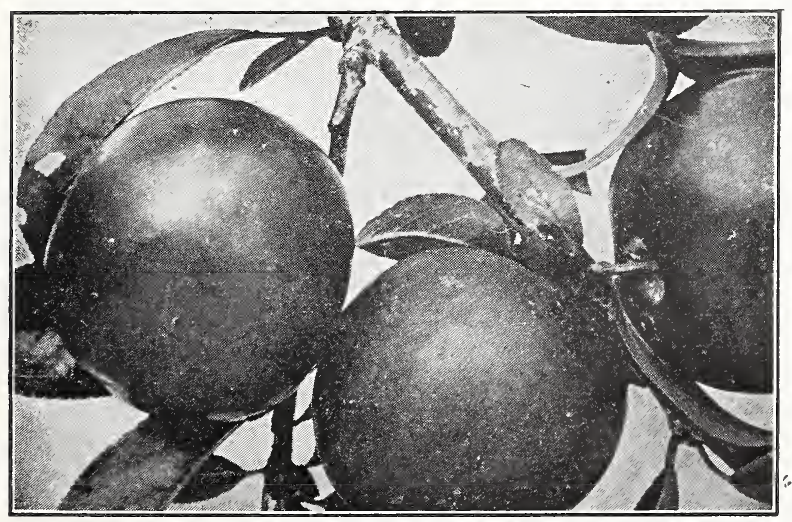

Excelsior Pluns.

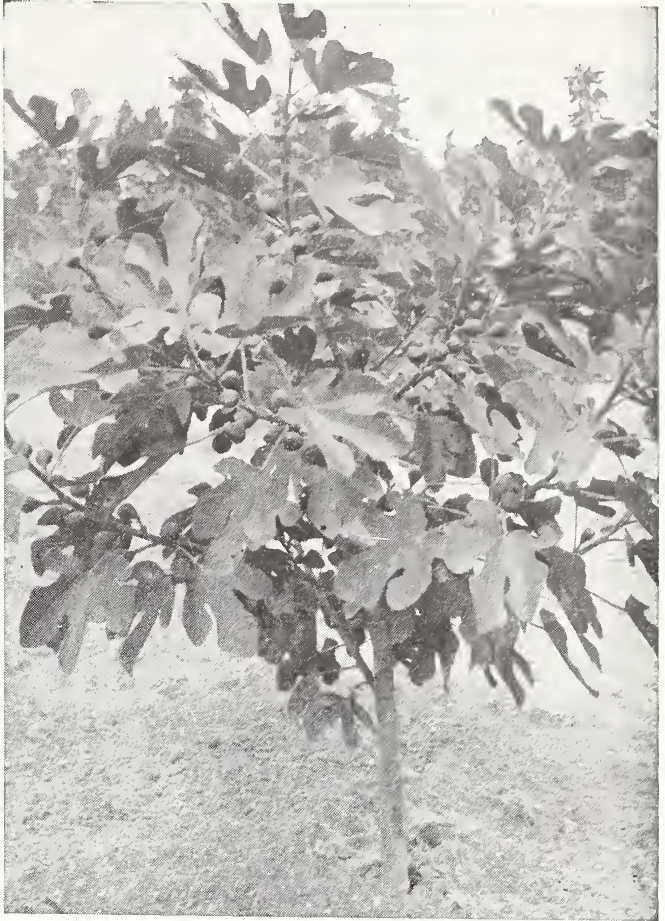

Fig Tree 18 Months From Planting.

\section{Figs}

Figs thrive in all portions of the cotton belt of the South as in no other section of the world; trees may be found growing in door-yards, near trash piles, in chicken runs, and near buildings in a most luxuriant manner and producing enormous crops.

No home pantry is complete without canned and preserved Figs for Winter use. Figs come into bearing very early. With proper spraying to hold leaves on, ruit may be had from

They require good fertilization, and do best on firm hard ground, kept free from all other growth.

Commercial Fig Growing is extending throughout the South. They can be planted 10 to 18 feet apart and the yield is very heavy, thousands of pounds of fruit being produced per acre.

ROWN TURKEY. Medium to large; yellowish brown; pulp tender, rich and of the finest quality, borne on long stems, allowing fruit to hang blossom end down at maturity, preventing souring in rainy

BRUNSWICK. Large, purplish black; good quality; early bearer; ripens throughout the season.

CELESTIAL, Sometimes called Little Sugar Fig; the sweetest of all varieties. Ripens in midseason.

EMON. Large, lemon colored, retaining natural color when preserved. Ripens

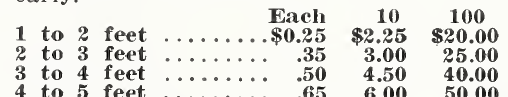

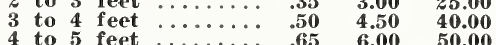

\section{Apples}

We do not recommend the Apple as a commercial possibility in the lower South: however, the better early summer types may be grown for home use.

EARLY HARVEST. Medium to large; pale yellow; rich, sprightly flavor. June.

HORSF. Large, greenish yellow. Popular southern variety. June $25 \mathrm{th}$.

RED ASTRACHAN. Medium to large, bright crimson; good quality and productive. June. RED JUNE, Medium size, bright red. Good quality. June. 3 to 4 feet, 60e each; $\$ 5.00$ per 10. 


\section{Mulberries}

For shade in back yards or lots and in poultry runs, the Mulberry is the best tree we know. The fruit will feed chickens or pigs for months. Mulberry trees thrive in any location.

HICKS' EVERBEARING. Enormous bearer; fruit ripening three months annually from June.

MERRITT. Finest Mulberry. The earliest variety; berries very large and full. Ripens during April A place in every home yard for this tree.

RUSSIAN. A favorite; ripens in May; bears young. Berries nearly black. Entirely hardy.

SILK WORM (Mom Multicaulis). Adapted to coast country; the famous silk worm tree. Special prices for Silkworm Farms.

\begin{tabular}{|c|c|c|c|c|}
\hline 3 to 4 feet & $\ldots$ & $\begin{array}{l}\text { Each } \\
.0 .50\end{array}$ & $\begin{array}{r}10 \\
\$ 4.50\end{array}$ & $\begin{array}{c}100 \\
\$ 40.00\end{array}$ \\
\hline 4 to 6 feet & $\ldots \ldots \ldots$ & .65 & 6.00 & 50.00 \\
\hline 6 to 8 feet & $\ldots \ldots \ldots \ldots$ & .80 & ร.50 & \% 0.0 \\
\hline 8 feet and & up ... & 1.00 & 9.00 & 80.0 \\
\hline
\end{tabular}

\section{Banana}

\section{(Musa Sapientum)}

No foliage so good in specimen planting or tropical effect for landscape massing and in most of the coast country produces nice bunches of really fine fruit. Grown throughout the south by taking up stalks in late Fall and burying, covering with leaves first, then soil. Soon makes beautiful showing when set out in spring, leaving fruit buds intact. Each 10

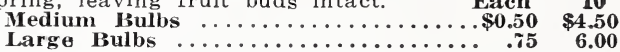

\section{Pomegranate} A novel southern fruit; highly appreciated by many
and thrives well. Quite ornamental. Varieties: Sweet and thrives well. Quite ornamental. Varieties. Swe and Sour.

2 to 3 feet
3 to 4 feet

3 to 4 feet $\ldots \ldots \ldots \ldots \ldots \ldots \ldots . \$ \ldots 0.35 \quad \$ 3.00 \quad \$ 25.00$

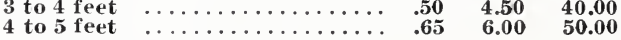

\section{Loquats}

or JAPAN MEDLAR (Eriobotrya Japonica). A conspicuously attractive small tree. Evergreen foliage. Bears yellow sub-acid plum-like fruit in very early Spring. Very desirable for its ornamental value and for fruit. Each 10

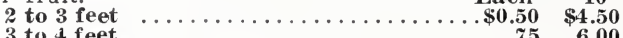

3 to 4 feet $\ldots \ldots \ldots \ldots \ldots \ldots \ldots \ldots \ldots \ldots, .75 \quad 6.00$

\section{Citrus Fruits}

We are in position to supp'y the very best quality of trees in all ciasses of Citrus fruits. For Central and South Florida, we recommend these trees budded on the Florida Rough Lemon Roots for planting on the high rolling pine lands, and the native Sour Orange Roots for level or flat woods land and all drained marshy or muck lands. For North and West Florida, South Georgia, and the coastal sections of South Carolina and the Gulf Coast states, the Citrus Trifoliate roots are best.

\section{Varieties of Oranges}

KING. Latest maturing of the Mandarin or kid glove type. Fruit large, flattened, flesh deep orange color. Quality excellent.

LUE GIM GONG. A late orange of very superior quality; awarded the Wilder Medal by the American Pomological Society for its late keeping and fine quality.

PARSON BROWN. Extremely early, standard round variety. The best orange in the market at its time of ripening. Medium size. Smooth skin.

PINEAPPLE. This is an ideal orange in shape, color and size; is unquestionably the finest flavored variety grown.
SATSUMA (On Trifoliate roots only). The great early market variety, always first on the market when prices are best. Adapted to all the heavy or clay sub-soils of North Florida, South Georgia, and along the coastal sections of South Carolina and the Gulf Coast States.

RUBY. Very early, dark, rich red. Ripe in early December. One of the best blood oranges.

TANGERINE. The best of the kid glove type. small to medium size, juicy, sweet, and of good quality.

YALENCIA LATE. Very late, large size, oval-oblong, thin, tough rind, rich, juicy, semi-acid. Fine quality, very heavy bearer.

WASHINGTON NAVEL. The orange that has made California famous as a citrus-growing state Entirely seedless, of excellent quality.

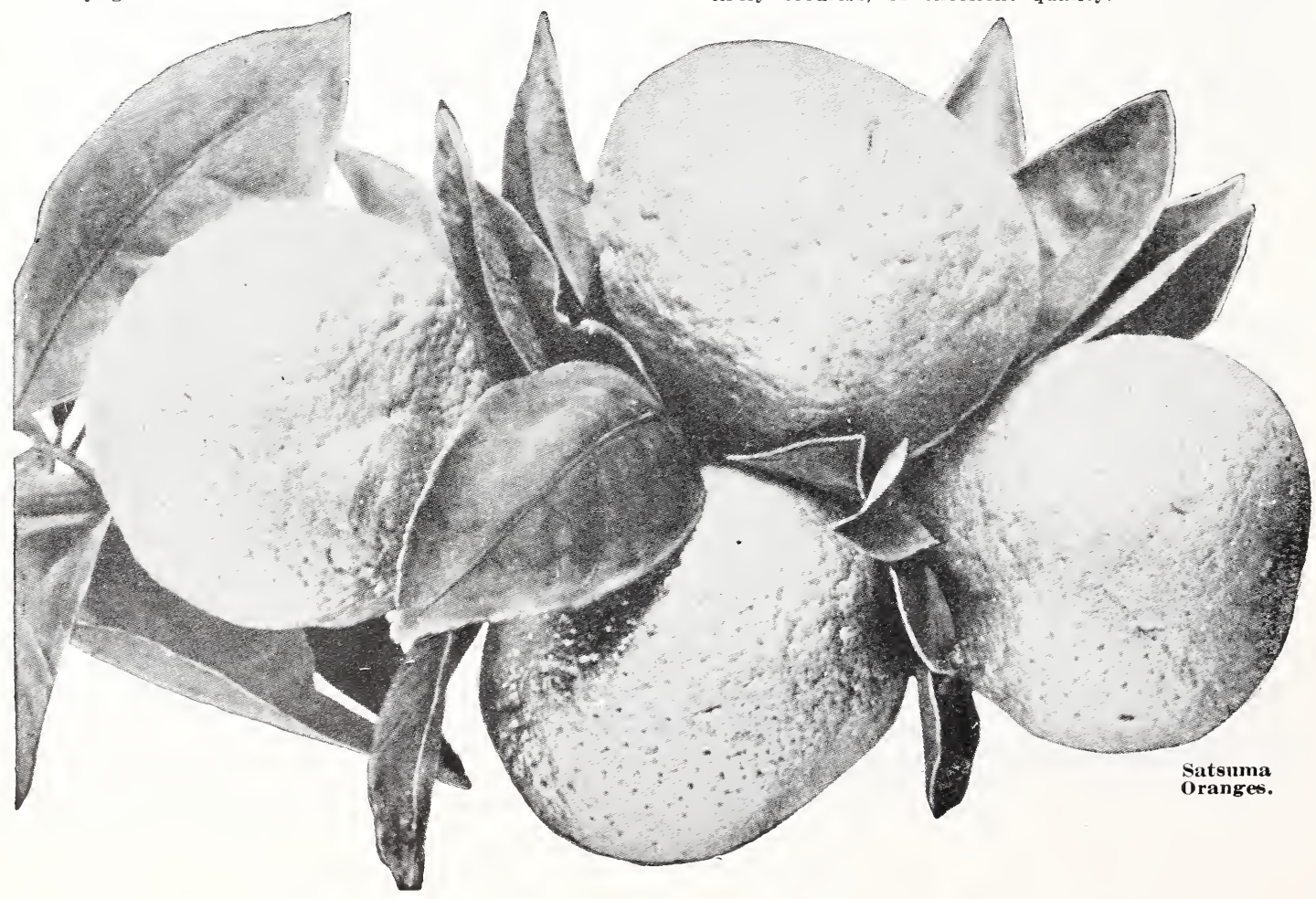




\section{Varieties of Grapefruit (Pomelo)}

DUNCAN. Medium to large; fine quality; good appearance; heavy bearer.

FLORIDA COMMON. Large, attractive fruit of original Florida type, the kind that has made Grapefruit popular.

MARSH SEEDLESS. Medium to large; very productive; bears extremely young; fruit popular on account of being nearly seedless.

TRIUMPH. Prolific; bears young; fruit small to medium; ripe very early in October.

\section{Varieties of Lemons and Limes}

DWIRF CHINESE. Valuable as a pot plant in the North, being very ornamental. In Winter "a small plant often has a dozen large lemons hanging on its branches," rather roundish in outline. This has proved specially hardy in Florida and the fruit is available almost the entire year. Juice very acid and valuable.

PONDERosa LAMON. American Wonder Lemon. Large, good quality, thrifty, prolific, early bearer.

VILLA FRANCA LEMON. Standard commercial varlety.

TAHITI LINUE. A large lemon-shaped Lime with smooth, thin rind; very juicy.

\section{Prices}

All Standard Varietics of Citrus, except Kumquats and Calamondins.

On Sour Orange and Rough Lemon stocks. Oneyear buds on 4-year root system.

\begin{tabular}{|c|c|c|c|c|}
\hline & Each & 10 & 100 & 1000 \\
\hline $3-f o$ & .\$0.60 & $\$ 5.50$ & $\$ 50.00$ & $\$ 450.00$ \\
\hline F-inch cali & . $\quad .80$ & 8.0 & 65.00 & 600.00 \\
\hline $\begin{array}{l}\text { s-inch caliper } \\
\text { t-inch caliper }\end{array}$ & 1.00 & $\begin{array}{r}9.00 \\
11.50\end{array}$ & $\begin{array}{r}85.00 \\
110.00\end{array}$ & $\begin{array}{r}800.00 \\
1000.00\end{array}$ \\
\hline $\begin{array}{l}\text { camper } \\
\text { caliper }\end{array}$ & ) 1 & 16.00 & 140.00 & 1250.00 \\
\hline
\end{tabular}

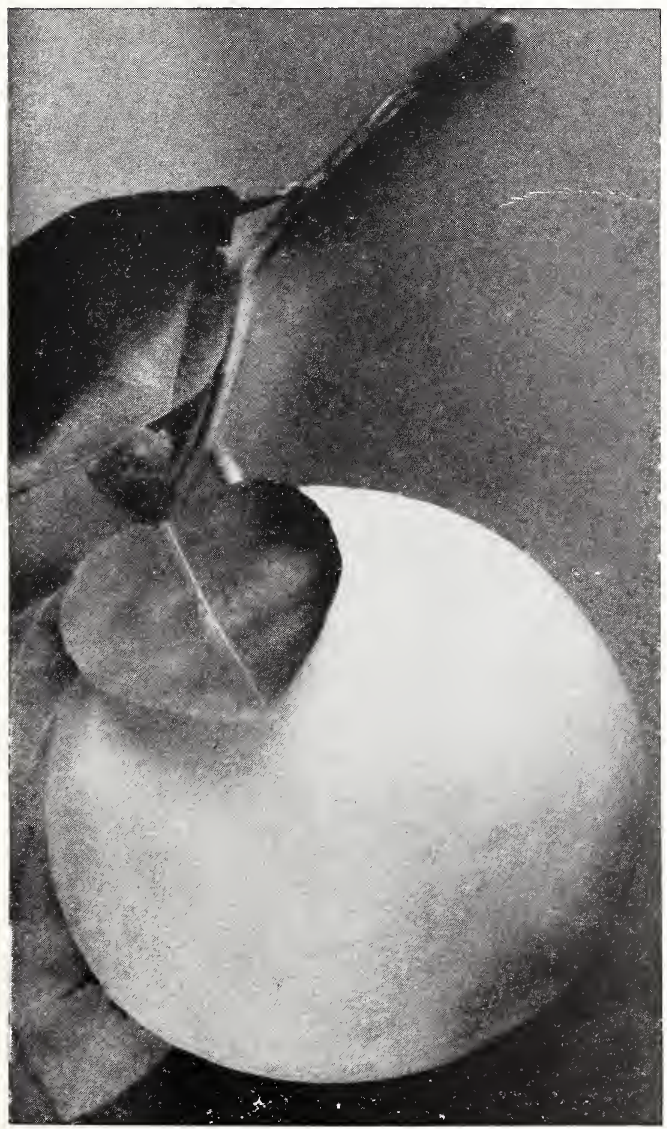

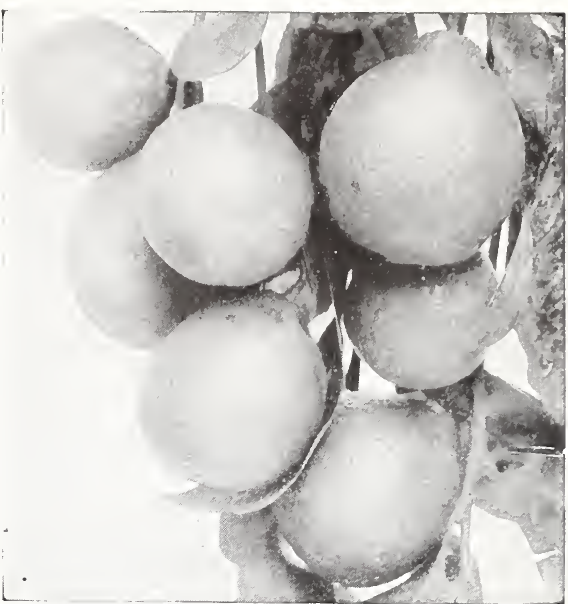

Lenions.

\section{Satsuma Orange}

The Hardy Orange for General Planting-in

$$
\text { Great Demand. }
$$

The Satsuma does not do so well on any other root except the Citrus Trifoliate. The early market Orange except the Citrus Trifoliate. The early market Orange known. There is no risk in growing Satsuma on Citrus known. There is no risk in growing Satsuma on Citrus second year after planting and becomes a profitable crop the third year thereafter. This is the ideal Orange to eat-the loose, tender rind or skin on the loosely adhering segments enable one to remove the segments or plugs and eat the fruit without the aid of a knife. Fruit medium size, flattened; color deep orange, flesh fine grained, tender, juicy, sweet and delicious, with a peculiar agreeable flavor found in no other Orange entirely seedless. Tree entirely thornless.

Satsuma and otler Standard Varieties.

On Citrus Irituliate stock.

\begin{tabular}{|c|c|c|c|c|}
\hline & & 1 & 18 & \\
\hline $\mathbf{f}$ & & $\$ 5.1$ & $\$ 45$ & \\
\hline 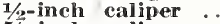 & & 6. & 60 & 0 \\
\hline ch calip & - 19.95 & $\begin{array}{r}8.50 \\
11.00\end{array}$ & $\begin{array}{r}80.00 \\
100.00\end{array}$ & 0.00 \\
\hline
\end{tabular}

\section{Special Citrus Fruits}

\section{Calamondins}

Fruit small, 11/4 inches in diameter. Orange-red. Thin skin easily separated from pulp. Strong, acid flavor. Ripens November and December. Very hardy. Dwarf habit of growth. Very decorative grown in tubs.

\section{Kumquats}

MARUMI. Fruit round, about one inch in diameter Pulp and juice slightly acid. Pleasant flavor. Very dwarf growth.

NEIWA. Fruit round, slightly larger than Marumi. Pulp sweet when fully ripe. Best of all Kumquat. to eat out of hand. Very dwarf growth.

NAGAMI. Fruit oblong. About $1 \frac{1}{2}$ to 2 inches long. Rind sweet, pulp and juice sprightly; fine flavor. Very dwarf growth.

All Kumquats are very fine to grow in tubs for ornamental purposes.

Prices on Calanondins and Kumquats.

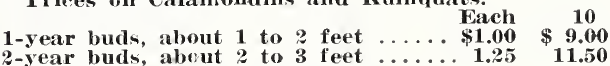

Best results will be obtained from digging a basin-shaped hole around each tree and shrub in late Spring, of sufficient size to hold a bucketful of water. In dry weather fill this natural basin several times a woek. At Winter's approach fill in with soil and bank up against the plant so as to afford Winter protection, restoring the eartlen basin in the following Spring. 


\section{Small Fruits}

\section{Grapes}

In the lower South two distinct types have proven their worthiness for general planting, and in no section can a greater quantity of the choicest fruit per acre, be produced. The Grape should be more generally planted in the home garden and commercial vineyards. arbor of some strong-growing variety of Grapes.

\section{SOUTHERN MUSCADINE CLASS.}

This class of Grapes is native to the South and is well known and loved by all southern people. Fruit clusters not so large as the varieties, but the flavor is excellent. For jellies, preserves, grape juices, wines and table use they are unexcelled. Usually trained on overhead arbors $6 \frac{1 / 2}{\text { or }} 7$ feet high, consisting of posts with wire or wood framework. Prunng is not commonly practiced. Plant 20 to 30 feet for arbors.

EDEN. Large, black; delicate flavor; large cluster; early bearer. Fine quality, productive, free from disease.

FLOWERS, Large, splendid quality. Very late. Black.

JAMUES. Very large, purplish black. Rich, sweet, juicy.

MALE MUSCADINE. If planted with other varieties of Muscadine Grapes, it will cause them to bear much heavier crops, as this is a pollinating variety.

MEISCH. New variety; medium size, earliest of this type. Delicate, rich, splendid flavor.

THOMLAS. Small cluster, medium size, red. Very fine quality. Early.

SCUPPERNONG. Large, bronze colored berry. Flesh sweet, pulpy and vinous. Vines produce abundantly.

\section{BUNCH CLASS.}

Not all bunch Grapes are at home in the South, but many grow here to perfection and can be planted in back yards or in commercial plant ings with assurance of prolific bearing. The best trellis is the Munson three-wire trellis, consisting of post. with cross-bars at top with three wires strung over tops for vine support. This type is usually planted 8 to 10 feet apart. Frune each Winter, leaving runners in each direction but removing the majority of last year's growth.

CARMAN. Vigorous, free from disease; prolific, large cluster. Berry medium size, black, firm, tender, fine quality. Very rich, superior flavor; seeds easily leaving pulp. A popular standard variety for the Gulf Coast and general South.

CONCORD. Blue-black; an old favorite.

DELAWARE. Bunches small to medium. Reddish pink. Sweet and juicy. Quality best.

IVES. Thrifty; productive; good shipper; large bunch; berry large, black, pulpy, sweet Good Grape. Good for shade arbors.

NIAGARA. White, large, showy; good market variety. MOORE'S EARLY. Bunches small; berries very large, round, blue-black, flesh pulpy, sweet; quality good. Very early.

Prices of all Grapes.

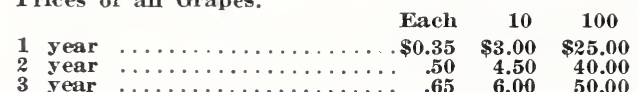

\section{Guava}

CATTLEY GUAVA. A vigorous evergreen shrub standing sharp frosts, having handsome broad evergreen leaves. Fruit small, averaging about an inch in diameter horne in enormous masses, ripening in August. Color a pretty red. Fruit is juicy and subacid, good in many ways. A fine plant, also of especial value for making hedges in South Florida, as it is unusually free from insect pests, such as white flies and scale.

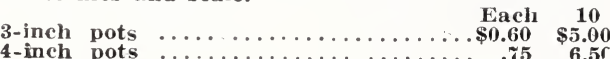

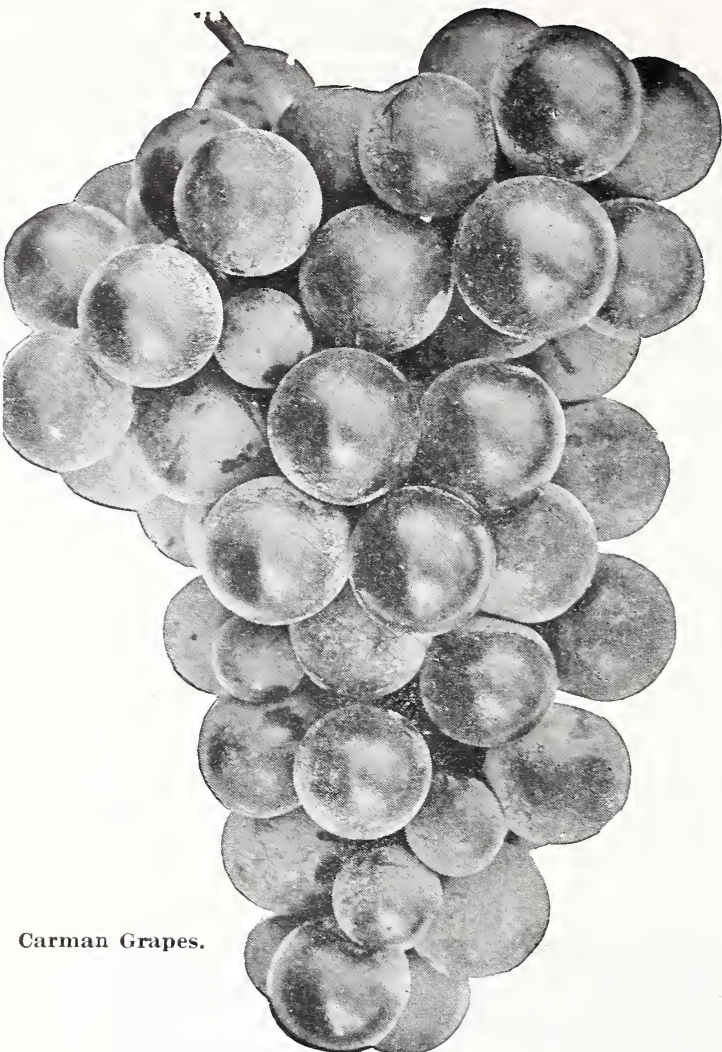

\section{Blackberries and Dewberries}

The fields and woodlands of the lower South are the native home of Dewberries and Blackberries. There is no place in the world where place are more productive or the quality hetter

The improved cultivated varieties offered here are varieties offered here are the choic of their kind and a few plants will give you a quantity of choice IARVEL BLACKBERRY. Originated at or near Daytona, about 1908 , and recognized by $\mathrm{Mr}$.

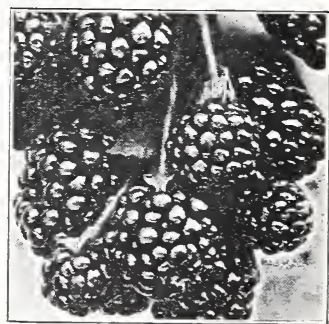
Blackberries.

W. E. Ballough (a trained horticulturist) as a very superior fruit, This is now our most widely grown "Blackberry," although it has the habit of a dewberry, with exceptional size and vigor. Should be grown on a trellis up to 5 feet high, with three to five Wires. Produces heavily for three to five weeks, in May and June, exceptionally large and juicy fruit that has met with instant favor at home, and promises much as a market fruit.

Price, 35c each; \$2.50 per 10; $\$ 20.00$ per 100.

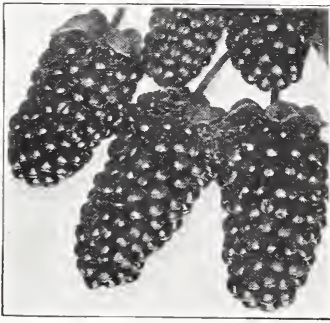

Dewberries.
LUCRETIA DEWBERRY. Berries a re larger and better than any bla ckberry. Soft, sweet and luscious. O color.

Price, strong plants, $\$ 1.00$ per $10 ; \$ 8.00$ per 100.

IUSTIN DEWBERRY Large, acid vigorous: prolific. Véry early.

Price, strong plants, $\$ 1.00$ per $10 ; \$ 7.50$ per 100. 


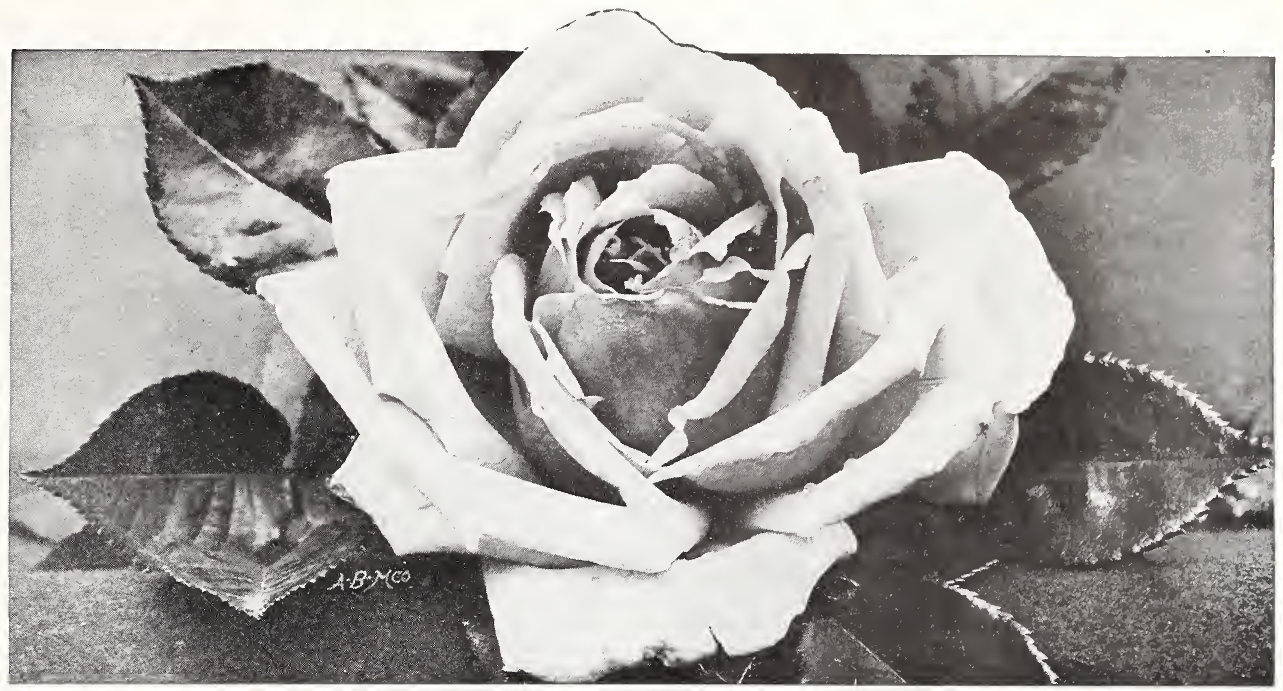

Alexander Hill Gray.

\section{Griffing's Roses the Queen of Flowers}

Plant Roses More Than Any Other Flowering Shrub. They Bloom in Our Southland from Eight to Twelve Months of the Year. Other Flowering Shrubs Seldom Have a Blooming Period of More Than One
Month.

Roses are the most popular flowering plant grown. We can never have too many around our homes; we and following our simple instructions, of Roses in the
sults gratifying.

The mild Winter, long Fall and Spring season, and abundance of rain during the Summer, give the lover of Roses in the southern states a more ideal climatic bed than any section in the world.

We offer only sturdy, field-grown Rose bushes that have actually proven themselves by producing an abundance of flowers in the nursery before they are dug and shipped. They are propagated on dug and shipped. They are propagated on produce free-flowering, strong. vigorous bushes. At time of shipping, plants are severely shipping, plants are severely pruned and defoliated, conserving in the root, main stalk and body of the bush, ling them to push out strong, ling them to push out strong, sturdy branches and produce oped flowers (when properly planted, manured and watered) in a surprisingiy short tered)

Our Rose Bushes are grown in the South especially for southern planting and will give sure and satisfac results.

Such bushes should not be Maman confused with imported cochet. plants, grown in entirely different soil and under differen climatic conditions, that have been dug and kept in storage or transit months before you receive them, such as are sometimes offered by department stores, etc., nor should ours be compared with the weakly hot-house-grown pot plants, propagated on their own roots from green wood cuttings, offered by plant firms in the North. There is no comparison elther in character of plants or in results.
Who Should Plant Roses. Everyone should plant Roses. There is no home. worthy of the name, where space could not be found for from ten to one hundred Rese bushes. If a renter, plant Roses; you will get returns in beautiful months. If a flat dweller, and you have three or more windows, you can plant ten or more Rose bushes in window boxes. The result will be a delight, and you can move the window boxes with other personal belongings when moving day comes around. If a home owner, it matters not how pretentious or humble, nothing can make it more homelike, more attractive and inviting, than

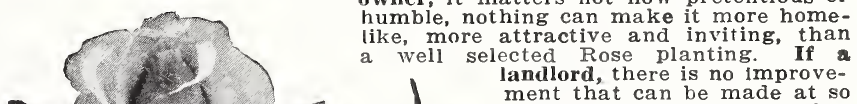
andlord, there is no improve-
ment that can be made at so small an expenditure that will so quickly enhance the rental value and desirability of property, insuring permanent tenants, as a good Rose planting.

Our Roses Are Known Throughout the South because they are vigorous and successful wherever planted. Many customers have placed orders with us for twenty years. If you want good Roses you can do no better than plant the Griffing Everblooming types.

\section{Strong Field Grown \\ Budded or Grafted Roses}

Classification: Roses are descended from several distinct classes or families, and the following key will enable one to find to which strains or classes each belongs. ( $\mathrm{H}$. P.), Hybrid Perpetual. ( $\mathrm{H}$. T.), Hybrid Tea (BK), Banksia. (Bour.), Bourbon. (Beng.), Bengal. (N.), Noisette. (Poly.), Polyantha. (H.' Ch.), Hybrid China. (H. N.), Hybrid Noisette. (T.), Tea. (Cl.), Climber. (H. W.), Hybrid Wichuraiana. (Laev.), Laevigata.

Prices of all Roses, except as noted Each $10 \quad 100$

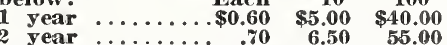
2 year
Radiance Red Radiance Charles Bell, Marechal Niel and Luxembourg :

$\begin{array}{rrrr}\text { 1year } & \ldots \ldots \ldots \ldots . \$ 0.80 & \$ 8.00 & \$ 60.00\end{array}$

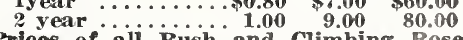
Prices of ali Bush and Climbing Roses. Balled and Burlapped, $\$ 2.50$ each. 


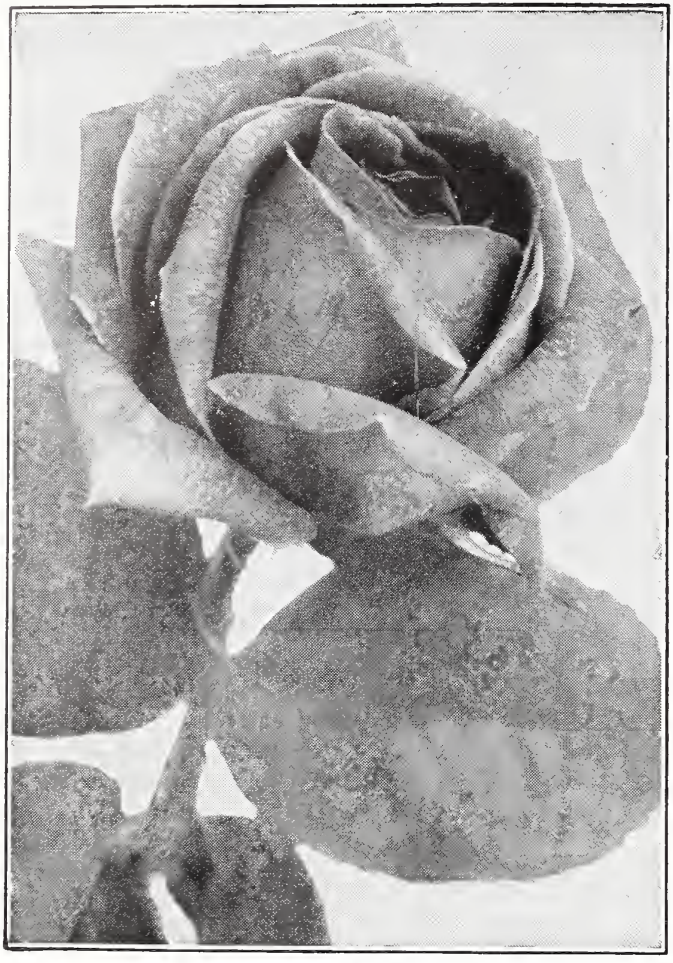

J. B. Clark Kose.

\section{Bush Roses}

Tree Roses: Radiance, Red Radiance.

Straight bodies, bare-rooted $\ldots \ldots \ldots \ldots \ldots . \$ 2.00 \quad \underset{\$ 17.50}{\text { Fach }}$ Straight bodies, bare-rooted $\ldots \ldots \ldots \ldots \ldots \ldots$
Straight bodies, balled and burlapped $\ldots \$ 2.00$

ALEXANDER HILL GRAY. (T). Color is deep lemonyellow, which intensifies as the blooms develop: flower large, which intensifes as the blooms develop; nower a high-pointed center from which the petals gracefully reflex.

ANNA MULIER. (P.) Plant stronger and flowers larger than the Baby Rambler type of Polyantha Roses. Color is briliant pink. It is very floriferous and sweetly scented. Excellent for border planting.

ANTOINE RIVOIRE, "MIrs. Taft." (H. T.) Creamy-white; delicately tinted with pink; extra large petals making a bloom of decidedly distinct and beautiful form; full and double. Medium upright growth and exceedingly well
adapted for garden culture; one of our best.

BABY RAMBLER, CRIMSON. (P.) The Crimson Rambler in dwarf form, with the same clear, brilliant ruby-red color. Hardy and healthy

BLACK PRINCE. (H. P.) Velvety crimson with shadiligs of purplish-black. Upright, strong growth.

BRIDE. ( $T$.) Most dainty, white with tinge of pink; with exquisitely beautiful long pointed buds borne on stiff, upright stems. Vigorous on strong land.

BETTY. (H. T.) Fine long buds, brilliant coppery rose with golden suffusion. Good foliage; strong, spreading growth.

BON SILENE. (T.) Bright crimson-rose; large, beautiful buds and blooms with very long petals; a well known old-timer, ever fresh and new.

BURBANK. (Bour.) Splendid symmetically formed cherrycolored blooms. Good grower and very free bloomer.

CAPTAIN CHRISTy. (H. P.) Delicate peachblow-pink, center riciser in color; large and full.

CHAS K. DOUGLAS. (H. T.) Bud large, long pointed; flower large, full, double, sweet fragrance; color intense flaming scarlet, flushed bright velvety crimson. Foliage dark green; disease resistant: vigorous, upright grower, produces an abundance of blooms from June to October.
CLIO. (H. P.) A vigorous grower producing handsome foliage; large, globular flowers of flesh color shaded to the center with rosy pink. Similar to Margaret Dickson.

COLUMBIA. (H. T.) It is a big Rose, the open flower measuring six inches across. The color is a true pink about the shade of a perfect Shawyer, deepening as it opens to glowing pink. A peculiarity of the variety is that the shades all become more rense unt? the full maturity of the open fower

DUCHESSE DE BRABANT. ( T.) One of the best allround roses ever introduced. Healthy grower, in blooms of delicate bright shell-pink. Large, spreading growth.

DUCHESS OF SUTHERLAND ( H. P.) Large, shapely buds and fine open flower of peach pink, strong upright grower.

ERNA TESCHENDORFF. (P.) The flowers are of a deep crimson color, flushed with carmine, resem bling the dazzling color of "Gruss an Teplitz." It is much sought after in America to bloom in pots during Winter and for Easter time.

ETOILE DE FRANCE. (H. T.) Lovely shade of clear velvety crimson. Fine cupped buds borne on strong, stiff stems. Profuse bloomer; spreading growth.

ETOLL DE LYON. (T.) Beautiful chrome-yellow. Pure golder

EUGENE MARLITT. (Bour.) A grand garden Rosenone better, being exceptionally healthy, vigorous and free blooming. Flowers large, very double, a rich bright crimson; fragrant.

FRANCIS SCOTT KEY. (H. T.) An American seedling, raised by John Ccok. It is a heavy, double Rose of great substance. In color, red; it show good growing characteristics and is undoubtedly valuable variety. Throughout the Summer this Rose was unequalled as a cut Rose, and is proving equally good in mid-Winter tu be an excellent grower, opening perfectly and worthy of unqualified recom-

FRAU KARL DRUSCHKI OF WHITE AMERICAN BEAUTY. (H. P.) One of the purest white roses splendid substance; borne on stiff stems. Upright. strong grower. 


\section{ROSES-Continued.}

FREIHERR VON MARSCIIALL. (T.) Deep carmine-red; long, well shaped buds and large, full flowers of imoricated form in wonderful profusion; a free and congrowth.

GENERAL JACQUEMINOT. (H. P.) Bright, shining crimson; very fragrant, free bloomer.

GENERAL MeARTHUR. ( $H$. T. ) Brilliant scarlet, large and double, borne on good
upright grower.

GENERAL ARNOLD JANSSEN. (H. T.) Color a deep glowing carmine. Free bloomer. Bud. long and poin.

GRUSS AN TEPLITZ. ( $\mathrm{H}$. T. Bright crimson, fiery red center; cup - shaped; semi-double; bloom as to present a blaze of scarlet.

HELEN GOOD, “Mrs. Dudley Cross." (T.) Beautiful, creamy white with delicate edgings of carmine at edge of petals and base of petals edge of petals and base of petals
rosy yellow. Fine formed buds rosy yellow. Fine formed buds opening into fuil, double blooms. Good bloomer.

J. B. CLARK. (H. P.) Intense flaming scarlet. Wel formed, cup-shaped blooms of splendid substance borne on upright, stiff stems. A strong grower and should be in every Rose garden.

JONKHEER J. I. MOCK. (H, T. Blooms are of the largest size, highly perfumed. Color clear imperial pink A gold medal winner.

JUSEPI HILL. ( $H$. T.) Salmon-yellow with pink edges: long buds and full flowers of great substance. Small, upright growth.

KAISERIN AUGUSTA VICTORIA. ( $\mathrm{H}$. T.) Pure white, with shadings of primrose-yellow.

KILLARNEY (Pink). ( H. T.) The popular Irish Rose Semi-dolible with immense petals of good substance Beautiful in the bud. Glowing pink. Vigorous, small, upright growth.

KILLARNEY QUEEN. (H. T.) Same habit of growth and free-blooming qualities as its parent, the Killarney, while its splendid petals are even larger and of a more while its sple
glowing pink.

KILLARNEY (White). (H. T.) Same good qualities of growth and habits as its parent, the Killarney, only petals are pure white.

LADY HILLINGDON. ( T.) Pointed buds of brilliant deep golden yellow. Awarded gold medal, N. R. S.
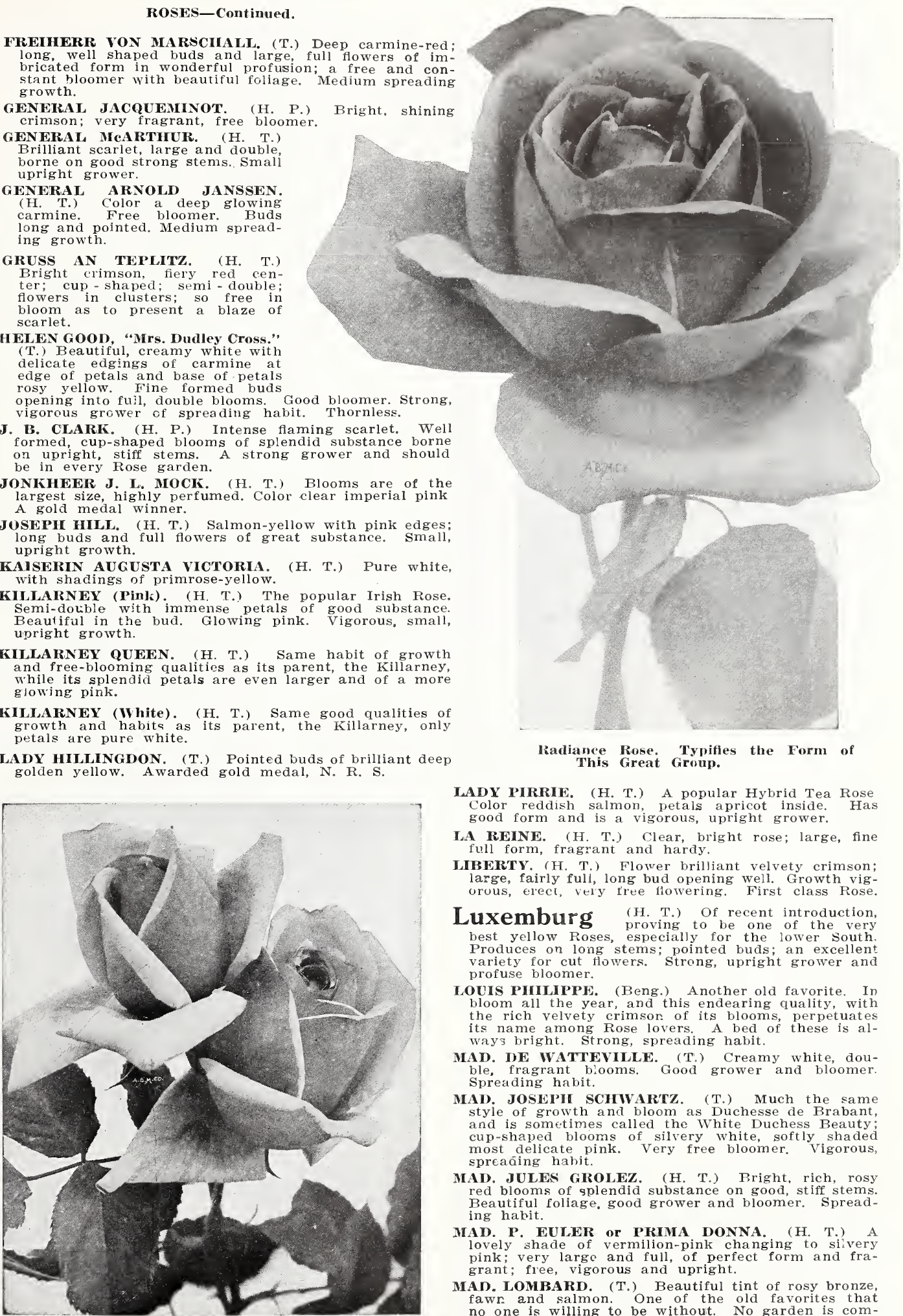

LADY PIRRIE. (H. T.) A popular Hybrid Tea Rose Color reddish salmon, petals apricot inside. Has good form and is a vigorous, upright grower.

LA REINE. (H. T.) Clear, bright rose; large, fine full form, fragrant and hardy.

LIBERTY. (H. T. ) Flower brilliant velvety crimson; large, fairly fuli, long bud opening well. Growth vig orous, ereet, very tree fiowering. First class Rose.

Luxemburg ( $\mathrm{H}$. T.) of recent introduction, best yellow Roses, especially for the of the very best yellow Roses, especially for the lower South. Produces on long stems; pointed buds; an excellent
variety for cut flowers. Strong, upright grower and variety for cut
profuse bloomer.

LOUIS PIILIPPE. (Beng.) Another old favorite. In bloom all the year, and this endearing quality, with the rich velvety crimsor of its blooms, perpetuates its name among Rose lovers. A bed of these is always bright. Strong, spreading habit.

MAD. DE WATTEVILLE. (T.) Creamy white, double, fragrant blooms. Good grower and bloomer. Spreading habit.

MAD. JOSEPII SCHWARTZ. (T.) Much the same style of growth and bloom as Duchesse de Brabant, and is sometimes called the White Duchess Beauty. cup-shaped blooms of silvery white, softly shaded most delicate pink. Very free bloomer. Vigorous, spreaóing habit.

MAD. JULES GROLEZ. (H. T.) Bright, rich, rosy red blooms of splendid substance on good, stiff stems. Beautiful foliage, good grower and bloomer. Spread ing habit.

MAD. P. EULER Or PRIMA DONNA. (H. T.) A lovely shade of vermilion-pink changing to sivery pink; very large and full, of perfect form and fragrant; free, vigorous and upright.

MAD. LOMBARD. ( T. Beautiful tint of rosy bronze, fawr and salmon. One of the old favorites that plete without them Vigorous pletea ding hatit

Jonkheer J. I. Mock. 


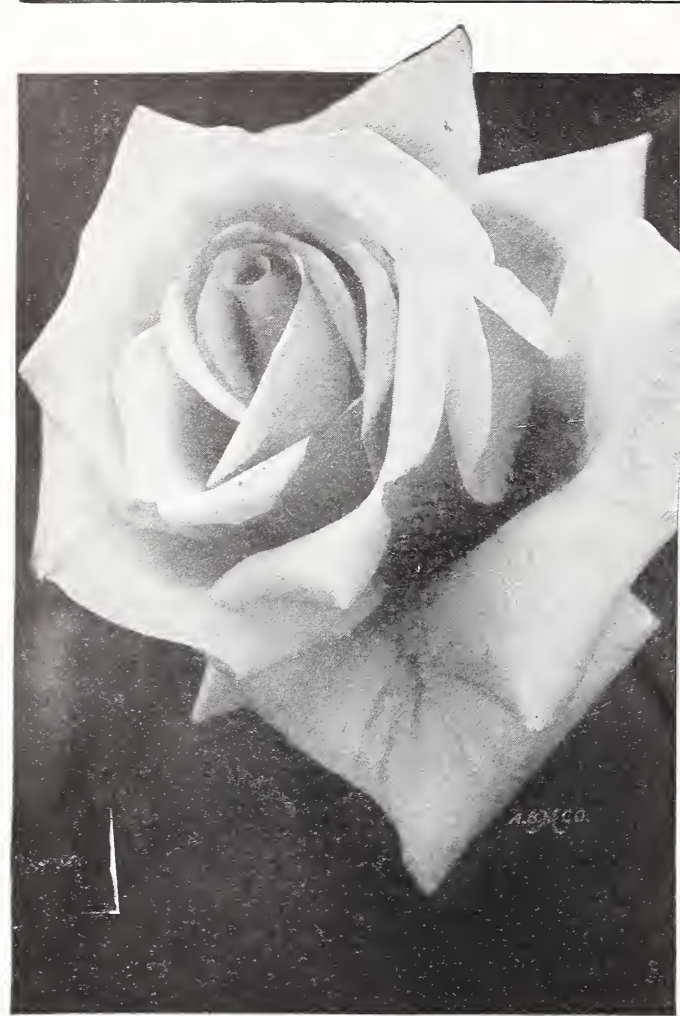

Columbia Rose.

ROSES-Continued.

MAD. CECILE BRUNNER. (H. Poly.) This is the popular Baby Pink or "Sweetheart" Rose. The past year or two this Rose has fairly jumped into
popularity. makes a handsome miniature Rose, coming in sprays of three to five buds. Color blush, shaded light salmon-pink; distinct and desirable.

MAD. MELANIE SOUPERT. (H. T.) A superb fancy everblooming Rose; of strong, vigorous growth and free branching habit. Color golden yellow shaded to orange-yellow at base of petals, the whole beautifully flushed with orange-pink. Fine long, pointed buds of elegant outline, opening into a very large, fluffy flower of great beauty.

MAMAN COCHET (Pink). (T.) Rosy pink, shadings of silvery rose. A splendid Rose of sturdy habits. Fine buds that last well cut, of large size and opening into full, double, fragrant bloom. Medium,

MAMAN COCHET (White). (T.) Of same sturdy habits, size, bloom and delicate fragrance as the Pink Cochet, and of such a pearly white and such exquisite shadings of most delicate pink that

MARGARET DICKSON, (H. P.) White with delicate flesh center. Best of white perpetuals. Vigorous, upright.

MAURICE ROUVIER. ( T. ) Strong growing, sturdy variety, producing an abundance of very large, full buds of a bright rosy pink, suffused with buff and crimson veins. Sometimes bordered with silvery pink. Very tall, spreading habit.

MIGNONETTE. (Poly.) Clear pink tinted with pale rose; very double and delicately perfumed. A perfect miniature Rose.

MRS. A. R. WADDELL. (H. T.) Buds long and pointed, of the deepest apricot-yellow, delicately pointed, of the deepest apricot-yellow, delicately ing well. Spreading habit.

MINNIE FRANCES. (T.) Rich chamois-red, shading to velvety crimson. Most vigorous grower of any we have ever known, making quite a shrub in two or three seasons, covered with bloom all the year. Buds daintily long and pointed.

MRS. CHLALES BELL. See Special Radiance Group. MRS. B. R. CANT. (T.) Color deep rose; inner petals soft silvery rose suffused with buff at the base.
PAPA GONTIER. (T.) Long, brilliant, cherry-red buds, semi-double, producing abundance of bloom at all seasons. Medium, upright growth. An old fa-

PIERRE GUILLOT. (H. T.) Large, handsome buds opening to flowers of the deepest, richest red. Medium. upright growth.

PAUL NEYRON. (H. P.) Largest Rose known, even surpassing hot-house American Beauties. Deep rosy pink, full, double blooms with spicy fragrance, borne on strong, upright stems. Vigorous grower and constant bloomer.

PINK FTAU KARL DRUSCHKI. (H. P.) Soft pink; very large, full and double. Vigorous, upright habit. Desirable.

PRINCESS DE SAGAN. ( T. Deep crimson. A good bloomer in cool weather when flowers are very showy. Small, spreading growth.

\section{The Great Radiance Group}

For outdoor culture in the South, we consider these the BIG THREE of all Roses. For cut flowers, they lead the field. Florists are depending on them (cut right from the onen) for the greatest part of the year. Wonderfully free bloomers, strong growers, large, shapely buds and full flowers on stiff stems.

\section{POSITIVELY THE MOST POPULAR ROSES IN}

\section{THE COUNTRY TODAY.}

Radiance (H. T.) Flowers are a beautiful shade the inner surface of the petals than pink, darker on the inner surface of the petals than on the margins.
The buds are large and very fine. There is no finer Rose grown than this.

Red Radiance (H. T.) Stands among red Roses ers of the same exquisite f a superior. It has flowfume, as Radiance. The color is a splendid, pershade of clear red, without a trace of any, even color, retaining its vividness for an unusually other time after being cut. It is a remarkabually long being freezing weather.

Mrs. Charles Bell (H. T.) A shell-pink Rapopular Rose. It has no diance, a sport of that it distinct from Radiance except that it is a light shell-pink. A grand Rose, always in bloom.

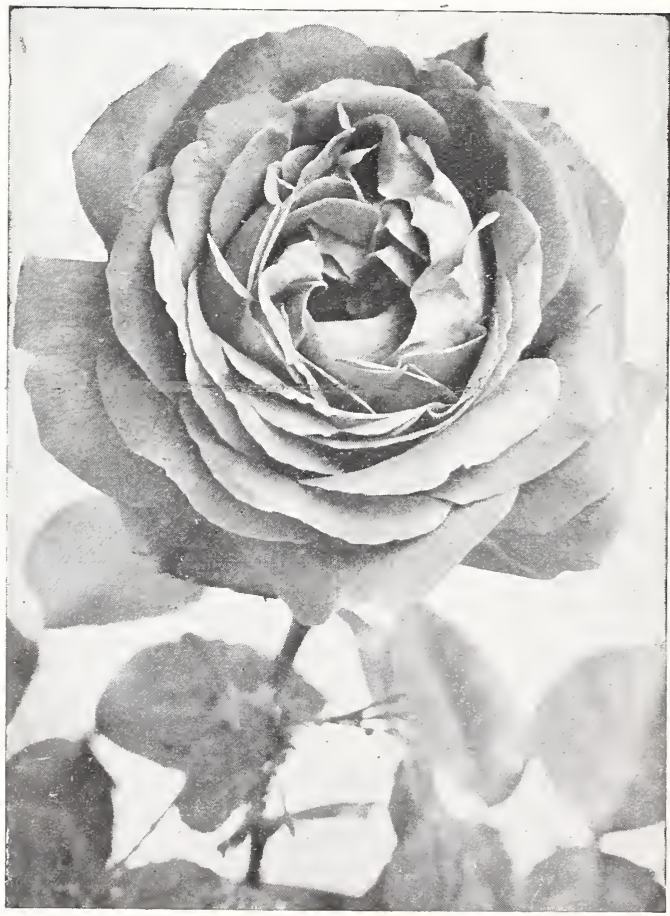

Etoile de France Rose. 
ROSES-Continued.

RED I.A FRANCE (H. T.) Much darker color than the old La France, also stronger and more vigorous RED LETTER DAY. (H. T.) An exceedingly beautiful Rose of infinite grace and charm. Its velvety, brilliant glowing scarlet-crimson buds and fully opened cactus-like flowers never fade, as the reflex of the petals is satiny crimson-scarlet. Awarded S. G. medal, N. R S.
RHEA REID. (H. T.) Flower large and double; rich dark velvety red; a good red garden Rose.

SAFRANO. (T.) Apricot-yellow, changing to orangefawn with reverse of petals tinted flesh-pink. Good grower. Spreading habit. SIR THOMAS LIITON. (R.) The best pure white Rugosa Rose. Strong and vigorous; grows four feet high. Flowers perfectly double, pure snow-white. SNOWFLAKE. (T.) Pure creamy white. Always a
favorite wherever grown. Vigorous grower of spreading habit. SOMBIEUIL. (T.) Large, full flowers of white with delicate salmon shadings. Vigorous, upright habit.
sUNIBURS'T. (H. T.) Long, pointed buds of richest coppery yellow, shading to golden yellow

ILLAM R. SMITH. ('T.) Exquisite blendings of soft pinlis and cream tints. Full, well-formed flow-
ers. Worthy a place in best selected gardens. Rank ers. Worthy a place in best select

WINNIE DAVIS. (T.) Soft apricot-pink shading to flesh tints. Very double, resembling a camellia when open. Splendid bioomer and vigorous grower. Tall, spreading habit.

\section{Climbing Everblooming Roses}

This selection of Climbers is everblooming, like the Teas and Hybrid Teas in the bush class. They produce fine flowers for cutting, are strong, vigorous growers, giving good results planted around porches, trained on small trellises or even as a yard Rose without support, if kept severely pruned.

CL. BABY RAMBLER. (Poly.) An everblooming true Crimson Rambler. Foliage never mildews.

CL. CAROLINE TESTOU'T. (Cl. T.) Vigorous climber, producing an abundance of large, cup-shaped blooms of most beautiful delicate pink.

CI. CLOTHILDE SOUPERT. (Cl. Poly.) White with delicate flesh tones. Very double and most fiagrant. Blooms in clusters.

CL. ETOIUE DE FRANCE. (Cl. H. T.) Identical with the famous bush Rose of this name, but a vigorous climber.

CL. GRUSS AN TEPLTTZ. (H. Ch.) An exact counterpart of the bush form of that superb Rose, Gruss an Teplitz, except that it is a vigorous climber. A fragrant sheet of dazzling crimson when in bloom.

HELEN GOULD. (Cl. H. T.) A perfect Helen Gould that is a strong climber, with handsome foliage;

JAMES SPRUNT. (Cl. Bengal). Deep cherry-red, very double and hardy.

CI. K. A. VICTORIA. (H. T.) Beautiful, large, double, white Rose of remarkable substance. CL. PERLE JES JARDINS. (Cl. T.) Color deep golden yellow; one of the best climbers.
MARECHAL NIFI, (Yellow). (Cl. N.) The grand IARECHAL NIFI, (Yellow). (Cl. N.) The grand
old southern favorite, with a fragrance equaled by old southern favorite, with a fragrance equaled by none. Full, double, golden yellow, produced abundantly all seasons of the year. Positively every home should have one or more of these grand climbers shedding their perfume at the door. More

PAUL's SCARLET. (H. W.) Vivid scarlet, shaded crims : makes a brilliant display for a long period crimson; makes a brilliant display for a long period of time in the garden. A wonderful new climbing
Rose. Received the gold medal and cup for the best Rose. Received the gold medal and cup for the best
new climber at the National Rose Society's exhibit. REINE MARIE HENRIETTA. (Cl. T.) Bright cherryred. Fine buds opening into large, delicately scented

SUNBURST. (Cl. H. T.) A climbing sport of that peer of yellow Roses. Sunburst, the much sought new French Rose. A true piliar Rose of strong growth, bearing freely, very large cadmium-yellow flowers. Beautiful either in bud or open.

WHITE MAMAN COCHET. (Cl. T.) Blooms the same color and size as the bush Maman Cochet, except that it is a strong climber.

WOO'TEN. (Cl. T.) Blooms large and full, crimson color. Strong grower; good foliage and constant

ZELIA PRADEL. (N.) Dainty pure white buds borne in clusters. Delicately fragrant. Half climbing. An old favorite.

\section{Climbing Rambler Type of Roses}

Much used in the North on account of their hardiness. Are valuable in the South, where rampant climbers are wanted. The flowers in the Spring are gorgecus.

BANKSIA. White. A rank-growing, thornless, old-
fashioned Rose. Blooms very early in the Spring. Flowers double, small but produced in great clusters.

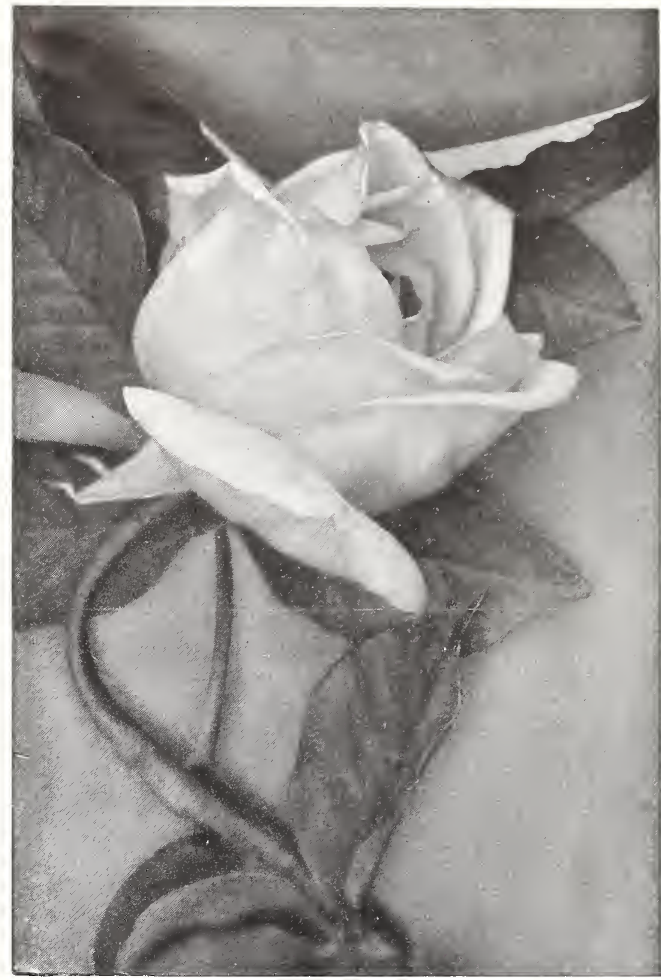

Marechal Niel Rose.

CHEROKEE. White. (Rosa Laevigata). The well known Cherokee of the South. A vigorous and flowers produced in early spring in great profusion; evergreen; foliage bright, glossy green.

CHEROKEE. Pink or Anemone. Flowers same as White Cherokee except that the color is glowing pink. They resemble huge apple blossoms.

DR. VAN FLEET. (H. W.) Rank climber, with the glossy Wichuraiana foliage. Flowers a remarkable shade of flesh-pink on the outer surface, deepening to rose-fiesh in the center; large and double.

EXCELSA or RED DOROTHY PERKINS (Walsh, 1909). (H. W.) Intense crimson-scarlet, double flowers in brilliant clusters set in glossy, shining foliage which never mildews nor spots.

GARDENIA. ( $H$. W.) Bright yellow, opening cream; early flowering, fragrant and free. Called the "Hardy Marechal Niel." Rank climber; thick, glossy foliage.

LADY GAY. (H. W.) Cherry-pink, fading to soft white. Blooms profusely in early spring. Flowers borne in large, loose trusses, often twenty or more

MANDA'S TRIUMPH. (H. W.) Pure white, well an entirely hardy climber or trailer.

SILVER MOON. (H. W.) Clear silvery white with a mass of bright ye low stamens, good foliage and a vigorous climber.

Sarasota, Fla. I am glad to report every one of my roses is growing and the Marie Van Houtte has seven budi. that will be open at the same time. Several have remarked on the fine strong plants I received for
my rose bed. Leesburg, Fla.

I got some roses from you a few weeks ago and am so well pleased with the stock that I wish to get a little other stock of you and wish you to
select it for me. 


\section{Evergreen and Deciduous Shrubs}

Lnder this broad classification comes the Broadleaf Evergreens, so numerous and valuable in the landscape plantings of the South, and also the gorgeons fowering shrubs which lose their foliage in Winter (deciduous). Fvergreens should predominate in southern plantings, where the Winters are mila and lawns look as beautiful in Winter as in summer We especially call your attention to the Broad-lea Evergreens, this class having received our closest attention for years, and many highly desirable older types being brought to the front and others introduced through our efforts.

To relieve the monotony of green tones, there should be a generous use made of the beautiful flowering flants we have selected and which do so well in the South.

ABELIA Grandiflora. A hardy, free-blooming shrub with shiny, purplish, evergreen leaves; bears a profusion of clusters of tubular-shaped flowers abou one inch long, white inside. Fragrant blooms last and foundation planting.

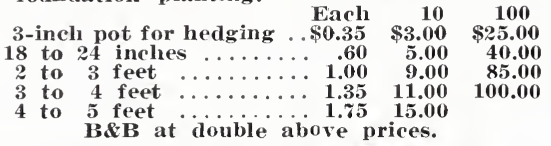

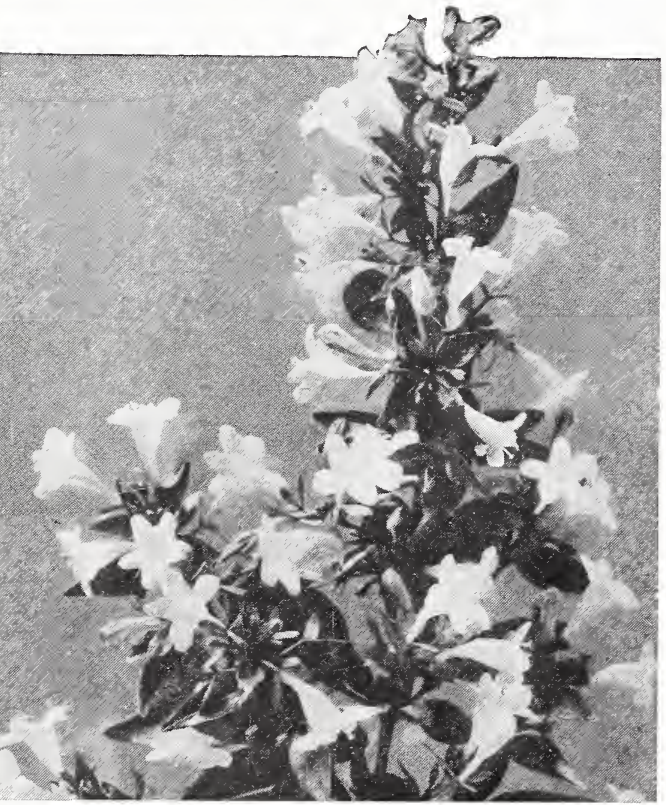

Abelia Grandiflora.

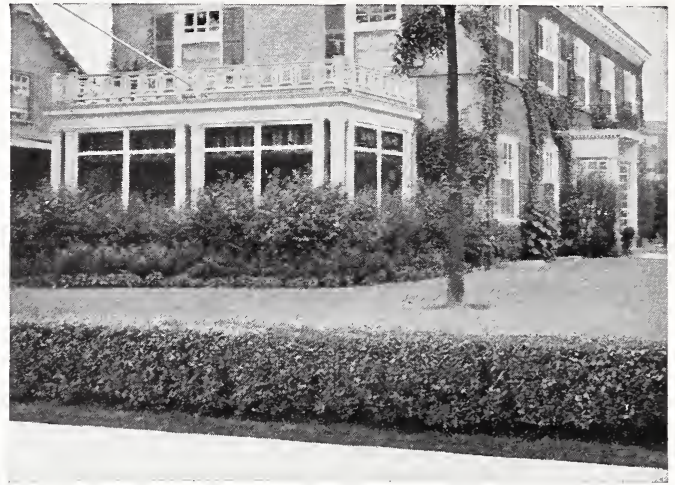

such Homes are Always Attractive.

ALTHEA, or ROSE OF SHARON (Hibiscus Syriacus). Well known free-blooming, upright shrub, bloomAmplissima. Double; deep purple-pink, with carmine center; tall growing

Boule de Feu. Double red.

Jeanne d'Arc. Double, pure white.

Peoniaeflora. White, with cherry-red center.

Rosea. Mixed colors; fine for hedges and massing.

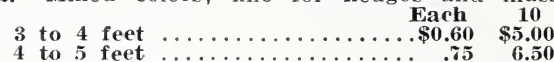

ARISISIA Crenulata. A compact evergreen shrub with thick dark green foliage and bright red berries which color during the late Fall and persist through the Winter. Fine for shade and half-shade Reaches a height of about $21 /$ feet and is a slow grower. 4-inch pots $\ldots \ldots \ldots \ldots \ldots \ldots \ldots+\underset{\$ 1.00}{\text { Each }} \mathbf{9 . 0 0}$ $\$ 1.00 \$ 9.00$ RDISIA Japonica. "ery much the same habit and character of growth as $A$. Crenulata, except berries produced are white. Very dwarf. Each 10

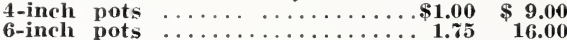

AUSTRALIAN SILK OAK (Grevillea Robusta). A tall, rapid-growing tree. Fernlike foliage. Can be topped to control height. Hardy as the orange trees; an excellent pot plant. 2 to 3 feet (pots) $\ldots \ldots \ldots \ldots \ldots \$ 0.50 \quad \$ 1.50$

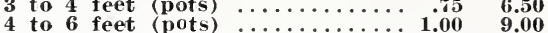

AZALEA Indica. One of the most satisfactory flowering evergreen shrubs for the lower South, where it is a mass of gorgeous flowers in Winter and early Spring. To get the best results, Azaleas should be planted in a somewhat shaded situation, especially sun of Sum

mer. The best

soil is one containing an abundance of leaf mold. peat and sand, but soil should be well drained. Azaleas will not suc with rotted leaves. Can supp.y following colors: Variegated, lavender. with rotted leaves. Can supp.
pink, and white and pink.

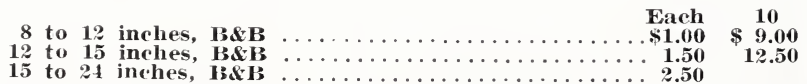

BACCHARIS Halimifolia (Salt Bush). A perfectly hardy native shrub of good growth and habit. Gray-green foliage. During late Fall the cloudy mass of white down used by Nature for transporting seeds makes the bush a beautiful sight.

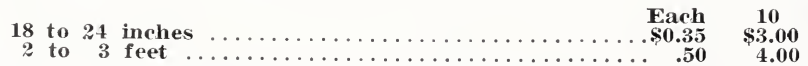

BOTTLE BRUSH SHRCB (Calistemon rigidus). Particularly interesting shrub with long, narrow leaves, with dense spikes of dark red flowers, taking the form of a bottle brush. Stands shearing.

4-inch pots, strong plants $\ldots \ldots \ldots \ldots \ldots \ldots \ldots \ldots \ldots \ldots+$ Each
6 -inch pots, strong plants

Each 10

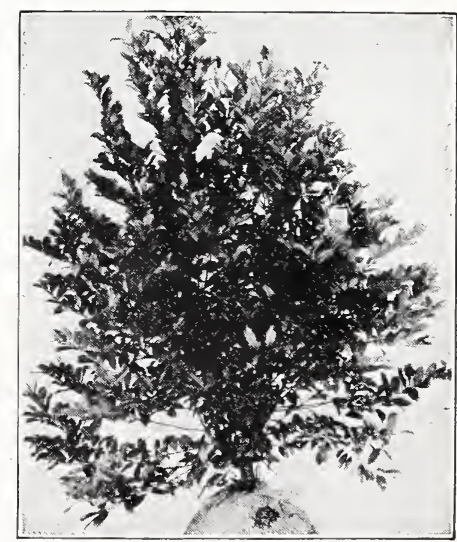

Laurel, Southern or Cherry

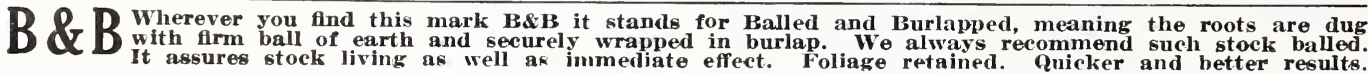


EVERGREEN AND DECIDUOUS SHRUBS-Continued.

BUXUS Japoniea (Japanese Boxwood). Small, glossy, light green leaves, evergreen; very distinct and valuable for edging, hedging and pruning into Boxwood specimens for tubs and urns. This is the only species of Boxwood that we have ever seen that will stand full sun in the lower Southland without burning. Dwarf habit of growth; hardy.

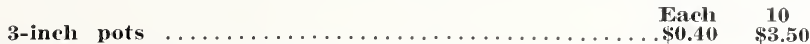

CAMELLIA Japonica. Well known Winter flowering shrub; evergreen commonly called Japonica. Leaves large, dark green and glossy; waxy double flowers suggesting the full blown rose but more formal in design. Red, pink and variegated.

1-year plants, potted or B\&B

Each 1.50

CAMPHOR, Bush Form (Cinnamomum Camphora). Exceedingly beautiful shrub. Can be kept in beautifully trimmed hedge less than two feet high. or allowed to make a bushy shrub twenty feet or more in height. Glistening foliage in light and dark shades of green, produced by young and old leaves. In Fall, a few leaves turn brilliantly crimson. New growth is wine colored passing through all tones to its mature dark green shade. Allowed to grow naturally, it makes a perfect, broadly rounded bushy clear to the ground, very compact For natural orouing cone, windbreaks and hedges, the Camphor is the most perfect plant. Fine specimens for lawns, also.

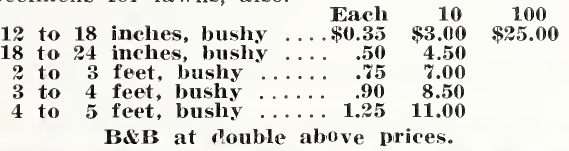

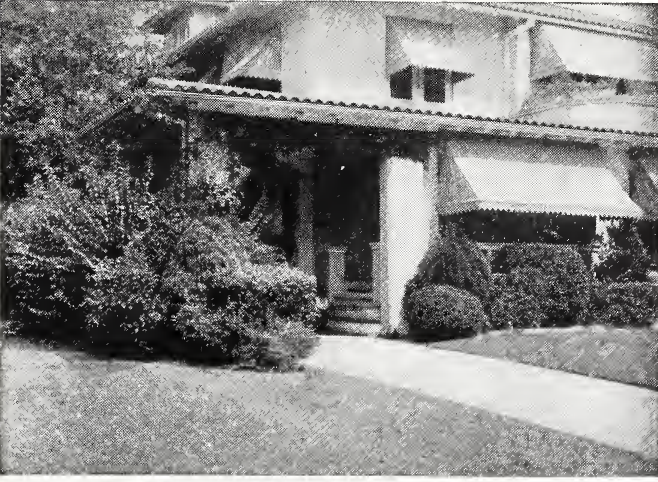

Entrance Planting.

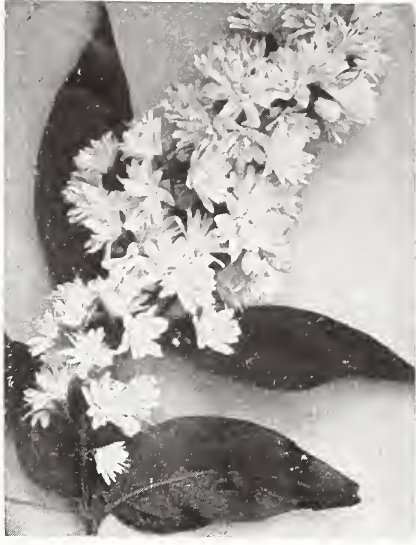

Deutzia, Pride of Rochester.

CAPE JASMLNE (Gardenia Grandiflora). The old southern favorite, with glossy leaves and masses of waxy white flowers; very fragrant. Attains excellent height for foundation planting, massing and for lawn specimens. Widely grown, hardy. The characteristic plant of the South. Blossoms highly valued in the North, where it is known as the Gardenia, of which romantic authors have written so freely.

8 to 10 inches ..........\$0.45 $\$ 4.00 \quad \$ 30.00$

12 to 18 inches $\ldots \ldots \ldots \ldots \ldots \ldots, .60 \quad 5.00 \quad 40.00$

18 to 24 inches $\ldots \ldots \ldots \ldots \ldots \ldots$. $.75 \quad 6.50$

CAPE JASMUNE, Everblooming (Gardenia Florida) An improved strain of the well known Cape Jas. mine or Gardenia Grandiflora. Blooms more or less the entire season, instead of spring only. Smaller blossoms, but very fragrant.

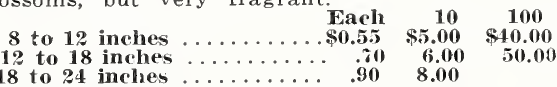

CASSIA Floribunda. A free-blooming plant. Large, orange-yellow, pea-shaped flowers, produced in great profusion from midsummer until Winter. Height 6 to 8 feet. A most effective lawn plant.

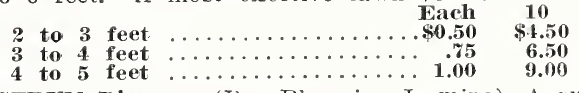

$\begin{array}{llll}3 & \text { to } & 4 & \text { feet } \\ 4 & \text { to } & 5 & \text { feet }\end{array}$

ESTRUM Diurnum (Day-Blooming Jasmine). A quick growing shrub of upright habit, dark green, glossy foliage. Produces quantities of small

CESTRUM Nocturnum (Night-Blooming Jasmine) Large, rankgrowing shrub with greenish colored flowers opening about sunset and emitting a very heavy fragrance. Blooms at intervals throughout the year.

Prices Day-Blooming and Night-Blooming Jasmines.

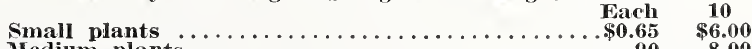

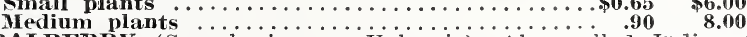
CORALBERRY (Symphoricarpos vulgaris). Also called Indian Currant. Fine low border plant for foundation or mass planting. Red berries remain on all Winter. As a colorful border for taller plants they are unexcelled. When placed in front of tall-growing conifers, they make pictures of unusual beauty. Foliage is dense, light green, pubescent underneath.

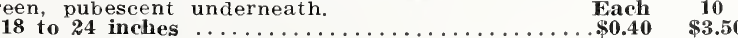

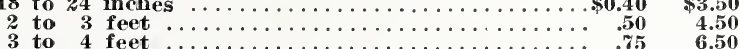

CUPHEA Hyssopifolia. "shrubby with pale lilac flowers and slender stems with small leaves. This bedding plant is well adapted for the edge of larger plantings or for carpet bedding. Easily grown and succeeds under trying conditions. Each 10

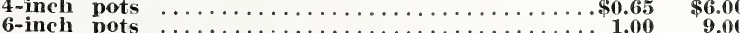

Orlando, Fla., Oct. 17, 1924. 11th shipping so promptly. Yours very truly, Stark, Fla., Dec. 12, 1924. Shipment of trees received the 10th. Everything in good condition and the nicest lot of nursery stock I ever saw. FRED CARITON.

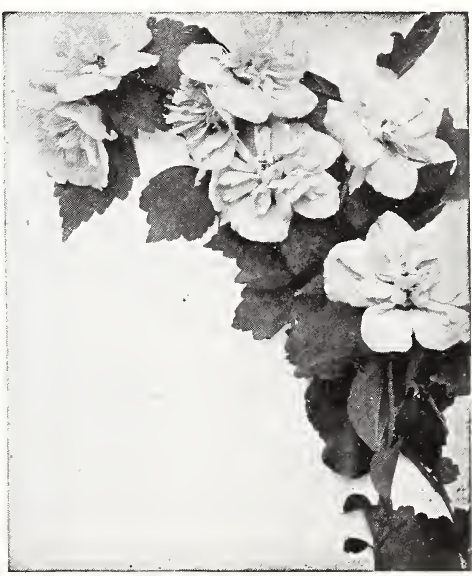

Althea or Rose of Sharon.

D 8 W Wherever you find this mark B\&B it stands for Balled and Burlapped, meaning the roots are dug with firm ball of earth and securely wrapped in burlap. We always recommend such stock balled.
It assures stock living as well as immediate effect. Foliage retained. Quicker and better resultis. 


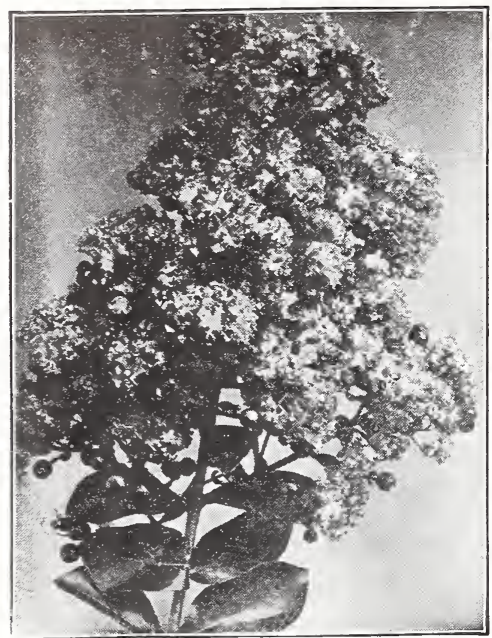

Crape Myrtle Blossom.

EVERGREEN AND DECIDUOUS SHRUBS-Continued.

\section{CRAPE MYRTLE - Lagerstroemia Indica}

The favorite flowering shrub of the South; hardy and heavy bloomer. Frequently termed the "Lilac of the South." There are two main types, the large or common strain, and the dwarf. The former can be grown in either large shrub or smali tree form. The dwarf forms are usually less than six feet in maturity and can be kept as low as desired by annual trimming as the flowers fade.

Crimson. Strong, upright grower; large regular formed flower clusters, bright crimson. For training into tree form.

Pink. Upright growth; large open flower cluster. One of the best and most profuse bloomers.

Purple. Upright growth, medium sized flower cluster lilac-purple shading to blush pink as flowers fade.

White. Medium growth; large open flower clusters. Clear pure white. Handsome as specimens on lawns, but its greatest value is for banking purposes along with the Dwarf Crimson variety among the evergreens.

Dwarf Crimson. One of the most popular shrubs

warf Crimson. One of the most popular shrubs with our trade. Rich crimson color characterizes the blossoms, which are borne in exceptionally large, fluffy heads often 10 inches long by 8 inches across. This new type should be widely planted. Very unusual color, seen in no other Crape Myrtle. A true dwarf. Of all flowering shrubs, this is the most
desirable in the South. It adds life, with its gordesirable in the South. It adds life, with its gorgeous colored, large flowers, for a long time in Summer and early Fall. Foliage is
Sometimes called Watermelon Pink.

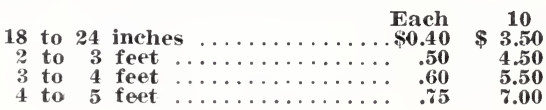

\section{DEUTZIA}

One of the most desirable shrubs. Their hardiness, iuxuriant foliage, and profusion of attractive flowers render them deservedly among the most popular of flowering shrubs. They are extremely florlferous and ornamental and make possible many striking effects in garden or border plantations.

Candidissima (Double White Deutzla). A tall shrub, attaining 5 to 6 feet, with numerous upright branches. A handsome, free-flowering shrub; blooms very early.

Crenata (Single White Deutzia). Flowers pure white and produced in great profusion very early in the Spring. A tall, thrifty grower.

Pride of Rochester. Tall-growing shrub, blooming first of April. Double white blooms with back o petals pink. Deserves a place on all grounds.

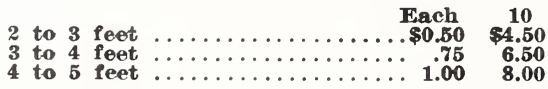

While our prices are as low as any, yet our aim is not to be the cheapest; value is our big consideration and aim. Constant care bestowed upon trees in bringing them to the best nurtured condition makes for cost. We could reduce nurturing cost and consequently selling costs, but that would not be giving Quality and Value. The best Value for the Money-that is our desire.

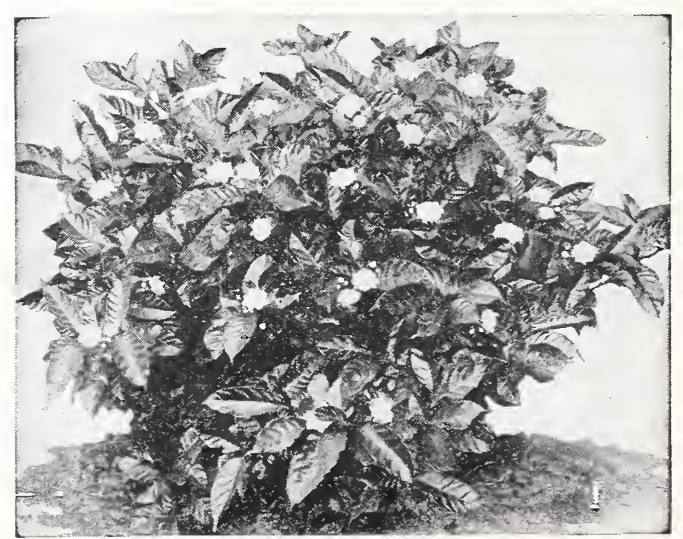

Gardenia Florida or Cape Jasmine in Flower.

D $R$ Wherever you find this mark B\&B it stands for Balled and Burlapper, meaning the roots are dug with flrm ball of earth and securely wrapped in burlap. We always recommend such stock balled.
It aseures stock living as well as immediate effect. Foliage retained. Quicker and better results. 
EVERGREEN AND DECIDUOUS SHRUBS-Continued.

EUGENIA Hookeriana (Bush Cherry). Very promising shrub for planting almost all over the state of Florida. Do not know how hardy it is, but do know that it is not in the tropical class, and probably will prove hardy over most of the state. Makes a large shrub, horizontal branching, glossy green leaves, evergreen; bears attractive small, red fruits.

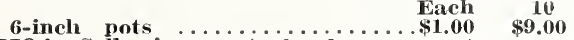
FEIJOA Sellowiana. " $\mathrm{A}$ hardy, compact, evergreen shrub with dark green foliage, grayish beneath, and purplish flowers. It is closely related to the Guavas, and the fruit is very good. This is a valuable addition to our list of shrubs.

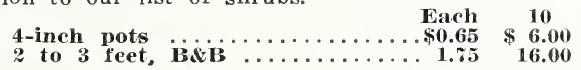

\section{FORSYTHIA - Golden Bell}

A valuable genus of shrubs producing golden-yellow flowers very early in Spring. Entirely hardy and of

Fortunei. Shrub of 8 to 10 feet, producing blooms in March.

Intermedia (Hybrid Golden Bell). A tall variety with slender arching branches. Flowers in great profusion. Attains 8 to 10 feet. Blooms early.

Suspensa (Drooping Golden Bell). A graceful variety with long, slender, drooping branches. Leaves dark, shining green. Blooms in March or earlier.

Virldissima. Profusion of blooms very early in Spring. often in February.

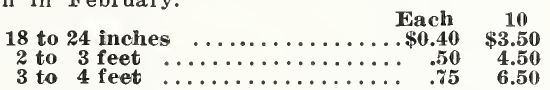

\section{HIBISCUS ROSA - SINENSIS}

(Chinese Hibiscus). Semi-hardy shrub with glossy green foliage and large. showy flowers. Freezes, but comes up from roots, blooming in short time. Single Scarlet, Double Red, Pink.

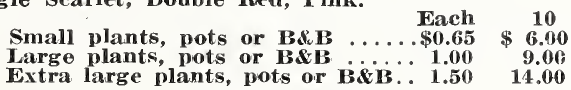

\section{HYDRANGEA}

Nearly evergreen in extreme South. Large, dark green, glossy leaves. Giant flower heads in various shades from pure white to deep pinks and blues, produced in great profusion in the spring and lasting nearly all summer.

HORTENSIS AND OTAKSA. Beautiful large heads, varying from pink to blue according to soil condi-

THOMAS HOGG. Pure white.

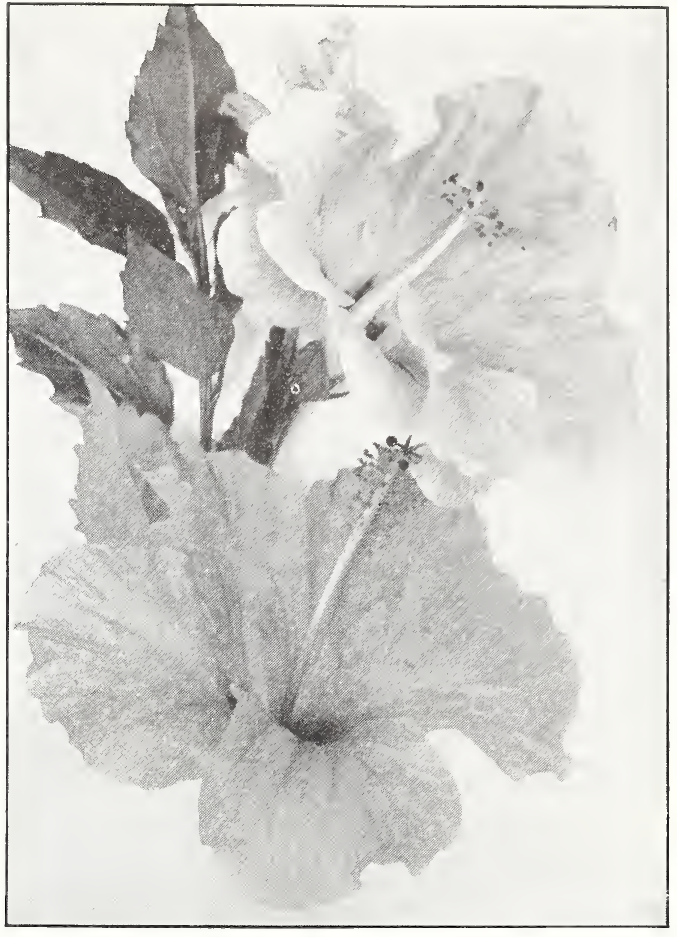

Hibiscus Sinensis.

\section{FRENCH VARIETIES.}

A new importation of assorted colors, pink, blue and white; glant heads. Grand shrubs for the South. Do best on north side of buildings or should be given partial shade.

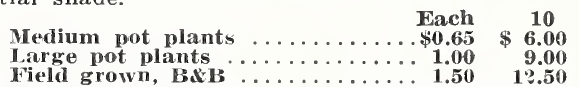

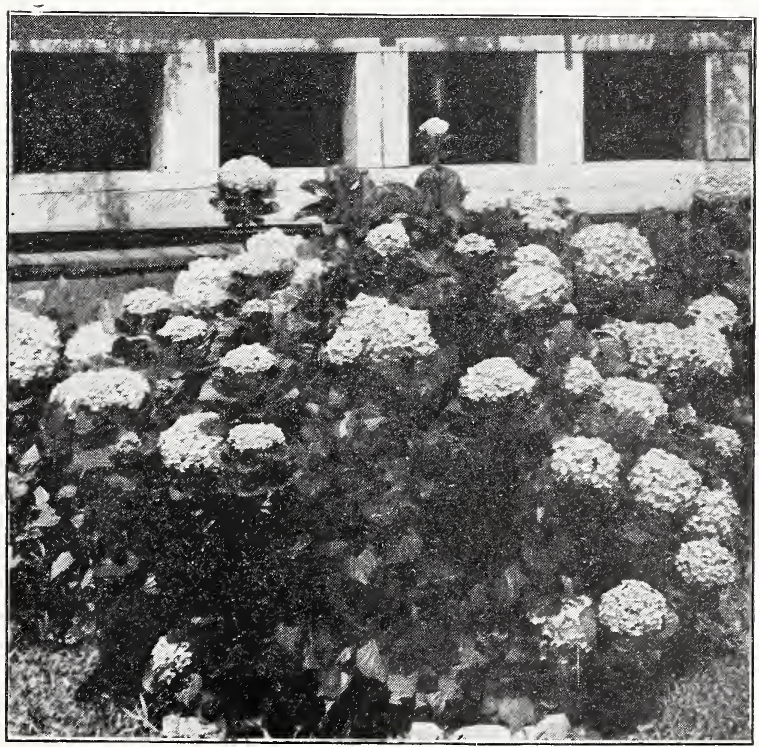

Hydrangea.

\section{ILEX GLABRA - Inkberry}

Handsome exergreen shrub with bright, shiny roundish leaves; grows well in any kind of soil and tends to spread and thicken. Very desirable for banking and mass planting.

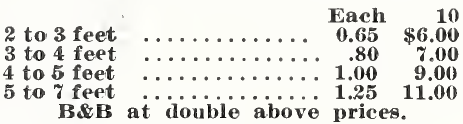

\section{ILLICIUM - Anisatum}

EAST INDIAN ANISE. (H. Japan). A handsome, broad-leafed, evergreen shrub of large size, 10 to 12 feet high, about as hardy as the Camellia. The aromatic foliage is eragrant when bruised. One of the very finest of all border shrubs as far as follage values are concerned.

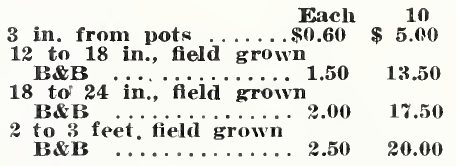
Wherever you find this mark B\&B it stands for Balled and Burlapped, meaning the roots are dug
with firm ball of earth and securely wrapped in burlap. We always recommend such stock balled.
It agsures stock living as well as immedinte effect. Filiage retained. Quicker and better results. 


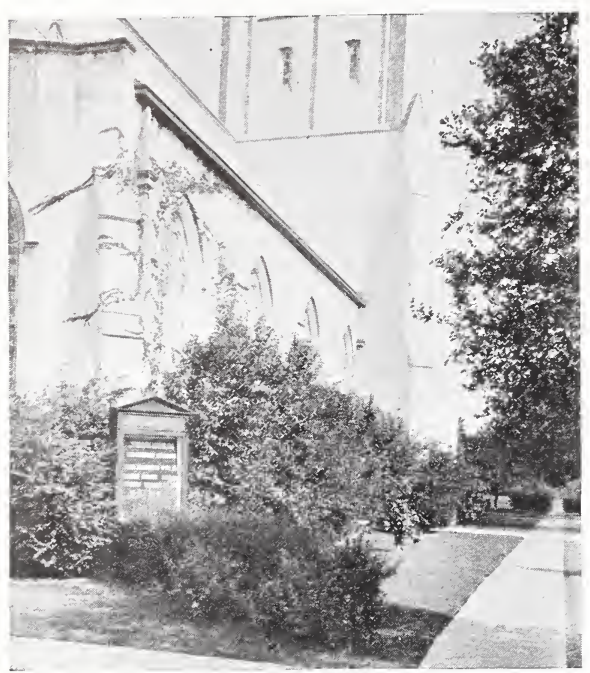

Church Grounds Beautified. Materiais Used Largely Ligustrum, in Variety. EVERGREEN AND DECIDUOUS SHRUBS-

\section{JASMINES or JASMINUMS}

These are among the prettiest and most valuable of our southern evergreen shrubs.

Pubescens. Beautiful, light colored foliage; very thrifty; hardy in lower South. Desirable for borders, beds and porch boxes. Can be trained as shrub or climber. The star-shaped, waxy white, fragrænt flowers produced in abundance nearly all the year.

Sambac, Large, flat, fragrant flowers. Is equally good as shrub or climber. Requires protection from frost north of extreme south and Gulf Coast section. The beauty and fragrance of its flowers once known can never ties: Grand Duke, double laid of orleans, single.

Price of Jasmine Pubescens and Sambac.

Pot plants, 6-inel Each ot plants, 6-inch
pots ........80.75 Humile. Evergreen in the lower South. Hardy north to Maryland. Leaves dark green; flowers bright yellow, produced in open clusters almost continually throughout the Summer

Primulinum (Italian Jas mine). Beautiful shrub with green stems and at tractive foliage; blooms early in Spring; hardy. Blooms in long sprays of scented, beautiful golden yellow flowers as large as
a half dollar. An exceed. a half dollar. An exceedingly valuable trailing shrub. Can be trained

Nudiflorum (Naked Flowering Jasmine). A low, graceful shrub with small, compound, green leaves; February a profusion of February a profusion of bright yellow, tubular flowers before the leaves
appear. Can be sheared appear. Can be sheared to form dense clumps. Mardy as far north as Maryland. Ultimate height
Prices of Jasmine Humile, Primulinus and Nudiflorum.

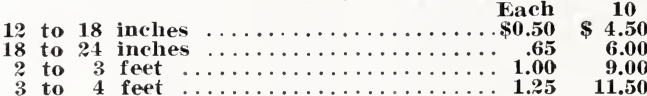

$1 B \&$ at double above prices.

\section{LAUREL, Southern (Prunus Caroliniana)}

Cherry Laurel and Wild Feach are other names for this plant. One of the most beautiful evergreens. Foliage is exceptionally glossy and a very rich green color. Naturally compact and symmetrical in form, it submits to shearing and can be kept in any form at any height. As a large shrub in foundation planting, or in groups, masses, borders, or screens, it has no superior. White flowers in Spring. Very hardy and

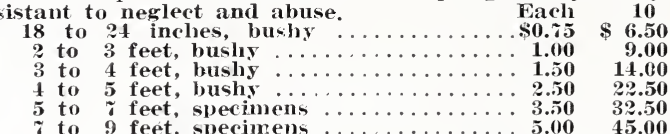

z to 9 feet, specimen. BdB at dowble above vices.

\section{Ligustrums}

GRIFEING'S SOUTHERN SFLECTION.

The Iost Popular IBroad-Leaf Evergreens.

A group essential to landscaping. The word "Ligustrum" (I.) refers to a large family of plants whose individual members are widely different in their various characteristics. The group is by far the largest and most generally successful among our broad-leaf evergreens. Individually and as a group their beauty is unrivalled. All of the Ligustrums are valuable for ornamental planting because of rich coloring, white blossoms are borne profusely in spring followed by showy fruits in shades of purple, resembling wild grapes. Our early recognition of the beauty and importance of this great group caused us to derote the closest attention to the observation, selection and development of the various types, and, with recent introductions we have made, together with and, with recent introductions we have made, together with for a simple classification of the pronour for a simple classification of the pronounced types for the convenience of our trade, and with the idea of encouraging greater familiarity with the new varieties among the many people who have of this group pared the following classification based on very broad principles.

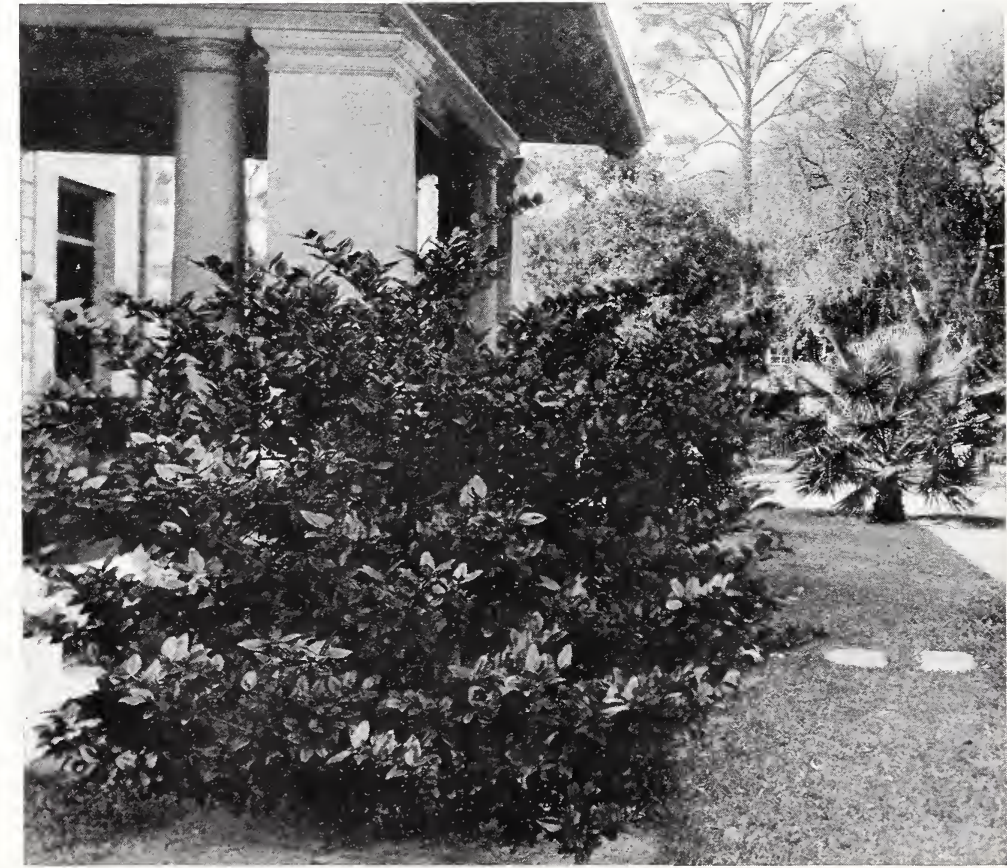

Ligustrum Lucidum.

D D Wherever you find this mark B\&B it stands for Balled and Burlapped, meaning the roots are dug with firm ball of earth and securely wrapped in burlap. We always recommend such stock balled. 
LIGUSTRUM-Continued. THICK GLOSSY LEAF TYPE (Lucidums).

The glossy leaf type is marked in having very glossy or shiny foliage of rich, dark green color, shading from almost black in some varieties to a light mottled effect in others. Height varies from low to tall and nature of growth is widely different in various varieties. This is probably the most distinctive type and has the highest quality and best texture in the family.

Griffing's Wax. The finest of all Ligustrums. Selected from among many thousands of imported Japanese plants, carefully preserved and kept to itself, we have developed the highly ima class all alone. In appearance it has the finest quality of any broad-leaf evergreen, and is exceed-

ingly hardy and resistant to abuse. The foliage is deep rich green, almost black. The leaves are very thick, beautifully shaped, and glisten as though polished. In its growth, this plant is very compact, dense and wide spreading, keeping greater width than height ordinarily. It is uniform in develop ment, maintaining a symmetrical form naturally It permits pruning and trimming to any desired shape, and when longer tips are pinched back, it increases its appearance. For permanent beauty, we unreservedly recommend the Griffing's Wax for foundation planting, beneath windows, at entrances to mark property lines and for bordering masses of high-growing shrubs. Will make excellent speci men plants or shearea hedges.

Iwata or Variegated Nepalense. Characterized by mottled shades of light yellowish green in center o leaves; this rather compact, low-growing Ligustrum is deserving of a place in every planting. Leave are small, thick, very shiny. Maintains a wide-
spreading, well-formed, symmetrical shape. Plant spreading, well-formed, sym
in front of Grifling's Wax.

Lucidum. Leaves large, thick, lanceolate, of a very dark shining green. Hardy at Baltimore. Re dark shining green. Hardy at Baltimore. Releaves farther apart on stems.

Nepalense. Medium size, dark green, glossy leaves uniform, compact spreading growth. A very at tractive plant, essential to landscape planting in masses, banking or groups. Fills space between rank growing shrubs and the very low growing types. Plant in front of Griffing's Wax.

Prices: 2- to 3-year trained bushy specimens.

Each 10

$11 / 2$ to 2 feet high, 11/2 to 2 feet

2 to 3 fect high, about ${ }_{2}$ feet $\$ 2.50 \$ 22.50$

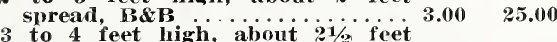

spread, BdB ............ $4.00 \quad 35.00$

feet and up, about $31 / 2$ feet
spread or more, B\&15 $\ldots . . \$ 5.00$ to $\$ 10.00$ each

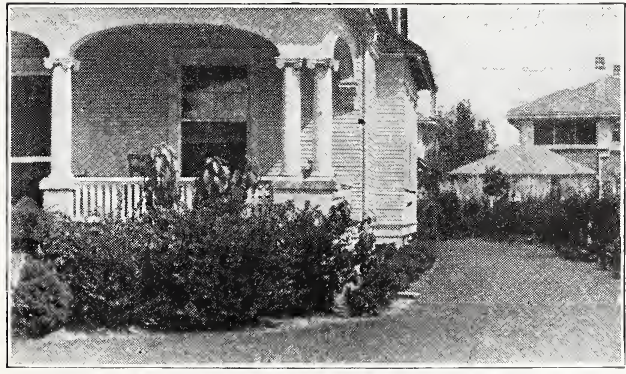

Showing Side and Backyard Planting.

$1 \%$ to $2 \mathrm{ft.}$, not balled $\begin{array}{ccc}\text { Wach } & 10 & 100 \\ \$ 1.00 & \$ 9.00 & \$ 80.00\end{array}$

2 to 3 ft., not balled... 1.25 11.00 100.00

BAB at double above prices.

Gracilis. A distinctive graceful variety which we have propagated from a seedling discovered in our nurseries. In mature development it has spreading upright growth with long branches recurving gracecal branching of our Nobilis variety. In height it ranks above the Griffing's Wax and other smallergrowing Ligustrum varieties and this controls its position in plantings. Foliage is dark green, glossy curled upward and distinctly pointed. Branche slender with shiny brown bark.

Folis Aurea. Bright golden-edged leaves and golden young growth make this variety very valuable in landscape piantings, for massing, banking or in contrast is made, effect is most pleasing. It holds contrast is made, effect is most pleasing. It hold. its leaves and puts on blue berries, making it very of these among your green foliaged evergreens for of these among your gree

Japonicum (Japan Privet). For a quick-growing, broad-leaf evergreen, this fills a large demand-for high massing and banking. Beautiful effect where a wide, high-growing plant is needed.
dark green. Sturdy, upright grower.

Nobilis (Formerly called Pyramidalis). Vertical in growth. The one broad-leaf evergreen that give good results for high points in a planting. Between whows, at corners, in front of columis and in back or lower growing plants, this tall, slender. dense, beautifully shaped plant is needed in quantity in every home planting. Include several in your is large size, rich, dark green.

1-year natural growth (not trained).

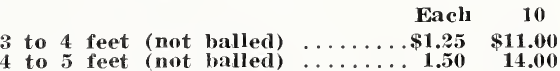

B\&B at double above prices.

NOTE. Our trained specimen Ligustrum Lucidum. Nepalense, Wax, Iwata, Nobilis, Folis Aurea and Japonica listed herewitin have all been pinched back and pruned several times during growing season, and trained to well rounded heads; every plant offered is a shapely specimen, and extremely desirable for landscape work and formal plantings where immediate finished effect is desired. We offer these balled and burlapped only.

D P Wherever you find this mark B\&B it stands for Balled and Burlapped, meaning the roots are dug $\mathrm{BC}$ with frrm ball of earth and securely wrapped in burlap. We always recommend such stock balled. 
EVERGREEN AND DFCIDUOUS SHRUBS-Continued.

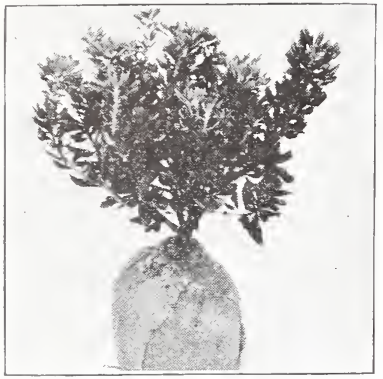
shrubby plant from tropical plant from Vigorous, luxuríant growth: used for ingrowth; used for inscape foundation and mass group; subject to freezing, bu comes back from roots, making a large bush in a popular colors offered.

4-inch Each 10 pots $\$ 0.65 \quad \$ 6.00$

Pittosporum Tobira.

\section{LONICERA - Bush Honeysuckle}

Practically evergreen in the South. Upright, bushy in habit. Beautiful flowers and berries. Good for massing and banking.

Nitida. Hardy, white blooming. Berries.

Morlowi. Strong growing; dark green foliage; white flowers in Aprii, followed by red berries.

\begin{tabular}{|c|c|}
\hline & Each \\
\hline 18 to 24 inclues &.$\$ 0.50$ \\
\hline
\end{tabular}

MALVAVISCUS (Turk's Cap). Will probably give an informal flowering hedge quicker than any other subject. Blooms continuously but especially during the Winter months. Will stand severe shearing, but being a broad-leaved plant, is best not cut back any oftener than is necessary, as the cut leaves give a ragged effect until the new growth comes out.

$\begin{array}{rrrrr} & & \text { Each } & 10 \\ 4 \text { to } 4 & \text { feet, field-grown, B\&B } & \ldots . \$ 1.00 & \$ 9.00 \\ 4 & \text { feet, field-grown, BSB } & \ldots & 1.50 & 14.00\end{array}$

MYRICA Cerifera (Southern Wax Myrtle). One of the niost attractive native evergreens; medium to large growth. A splendid shrub for group and foundation planting. Broad, dark green foliage blending well with other plants or making a single, striking specimen.

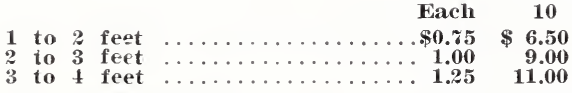

\section{OLEANDER - Nerium}

Evergreen; bearing long, narrow leaves and very brilliant heads of colorful blooms; good for outside effect and beautiful for tub planting. Upright growth, good for massing and foundation planting. Unsurpassed as a lawn specimen or shrub to alternate with street trees or beautify a boulevard or park. If tops free back in more northern locations, it will com out from the roots with luxuriant growth.

single White. Single, white flowers of good size in large clusters.

Double Pink. Double, deep pink; very large; free bloomer. Best for general planting.

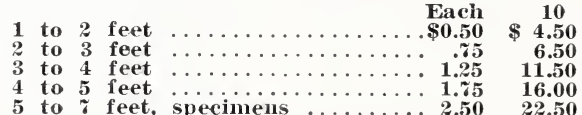

5 to 5 feet, specimens $\ldots \ldots \ldots$ 1.55 16.00

BAB at double above prices.

SPECIAL VARIETIES OF OLEANDERS.

Atropurpureum Plenum. Double purplish crimson sional narrow white stripes. The deepest red of any sort.

Doctor Golfin. Magnificent single flower; bright deep pink, almost red: scented,
opens early in the opens ear

Madonna Grandiflora.

Pure white, dou-

ble, of large size; very rragrant. The

best of the double Nandina-Scarlet Winter Color.

Nankeen. Single, yellow; of open growth; very attractive

$$
\begin{aligned}
& 2 \text { to } 3 \text { feet } \ldots \ldots \ldots \ldots \ldots \ldots \ldots \ldots \ldots
\end{aligned}
$$

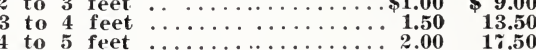

$$
\begin{aligned}
& \text { B.EB at double above prices. }
\end{aligned}
$$

Fvergreens, whether in Winter or in Summer, are a permanent pleasure. A home in a pretty setting of Evergreens is a picture of warmth and comfort in Uvinter, and is cool appearing and as inviting a retreat in summer as the virgin forest.

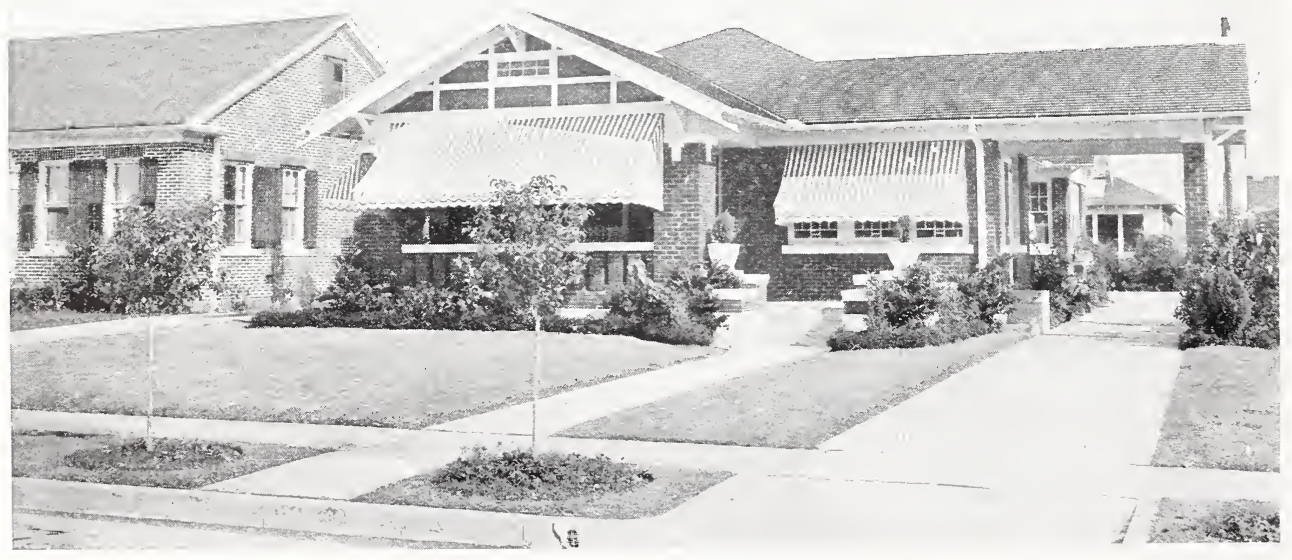

Newly Planted Ligustrum, Pittosporum and Conifers; Immediate Effect.

D D Wherever you find this mark B\&B it stands for Balled and Burlapped, meaning the roots are dug $\mathrm{B} \& \mathrm{~B}$ with firm ball of earth and securely wrapped in burlap. We always recommend such stock balled. 
EVERGREEN ANU DECIIUOUS SHRUBS-Continued.

PHILADELPHUS (P. Grandiflora). (Mock Orange or Syringa). Fine old shrub with white blossoms, similar to orange blossoms, borne early in Spring.

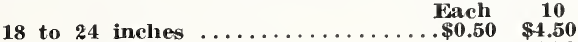

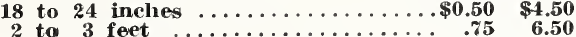

PHOTINIA Serrulata (Dententa). Beautiful, iargeleafed, hardy evergreen supplying the foliage texture of the northern Rhododendrons and English Laurels. Delightful contrast in shades of new and old foliage. the brownish red stems at tips, and the older leave taking on brilliant crimson color in winter. particularl with fawn tinted brown leaves and red stem in spring. Topping the long branches makes it very dense and extremely bushy.

$$
\begin{aligned}
& 18 \text { to } 24 \text { inches } \ldots \ldots \ldots \ldots \ldots \ldots \ldots \ldots 1.00 \quad \begin{array}{c}
\text { Each } \\
\$ 9.00
\end{array} \\
& 2 \text { to } 3 \text { feet } \ldots \ldots \ldots \ldots \ldots \ldots \ldots \ldots \ldots 1.50 \text { \$ } 13.50 \\
& 3 \text { to } 4 \text { feet } \ldots \ldots \ldots \ldots 2.00 \quad 12.50
\end{aligned}
$$

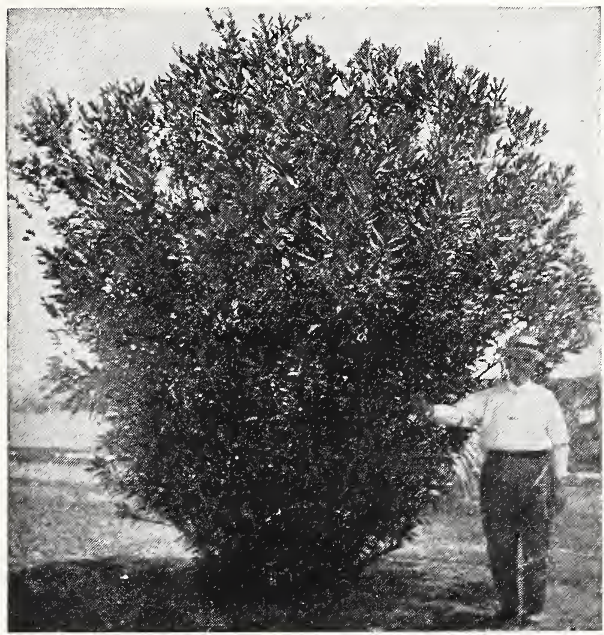

Oleander Splendens.

PITTOSPORUM Tobira. An evergreen unequalled in desirable peculiarities. Can be sheared to any desired shape, or permitted to grow informally, forming a very bushy, compact, wide-spreading shrub. Small creamy blossoms of deliglitul fragrance. For massing and foundation planting it is one of the best. Juxurious growth, round lawn perfectly.

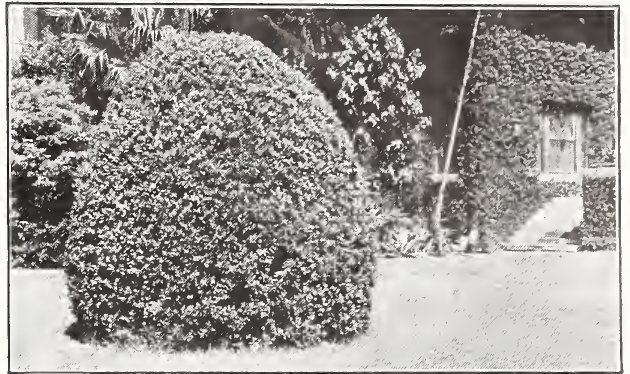

Sheared Griffing's Wax Ligustrum.

PITTUSPORUM Tobira Variegatum. Same as above, except has light green foliage, variegated with white. Very showy and useful for mass and foundation planting where color is desired.

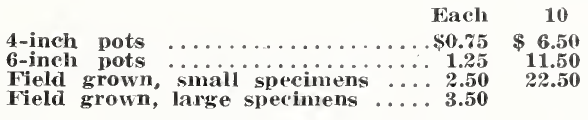

Note. Can supply P. Tobira Variegatum only in 4 -inch pot size.

Plunbago Capensis (Blue Leadwort). Beautiful, small to medium shrub, bearing a wealth of light blue, Phloxlike blossoms. For interplanting; foliage is fine, light green in color. Comes up from roots if frozen back.

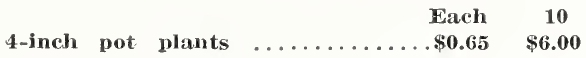

POMEGRANATE, Flowering (Punica Granatum). Very dense, bushy shrub with glossy foliage. Great abundance of colored blossoms, making very attract

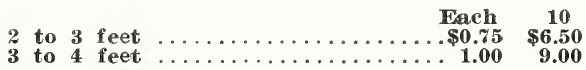

PURPLE LEAF PLUM (Prunus Pissardi). Also called Thundercloud Plum. Foliage of rich reddish purple, exceedingly valuable for color effect in massing or groups; makes large shrub or small tree. Acid fruit.

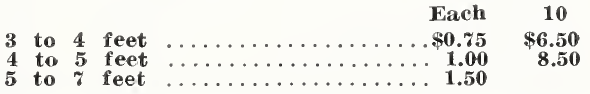

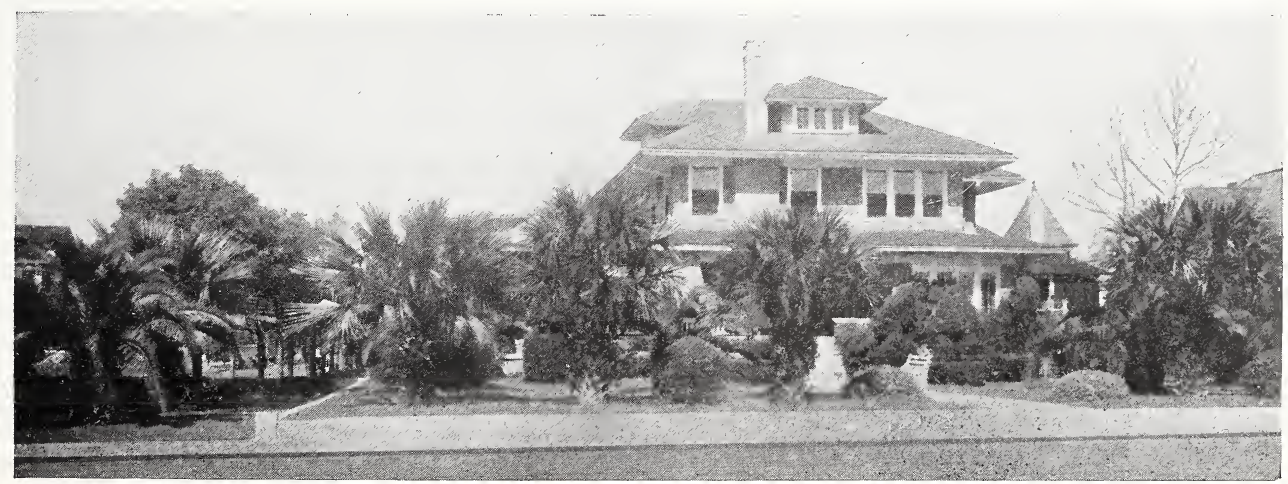

Palms in Variety. Sheared Pittosporum and Laurel Cherry.

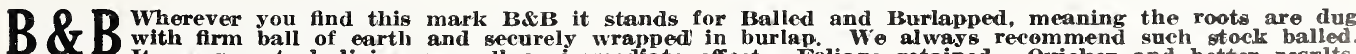
It assures stock living as well as immediate effect. Foliage retained. Quicker and better resnlts. 


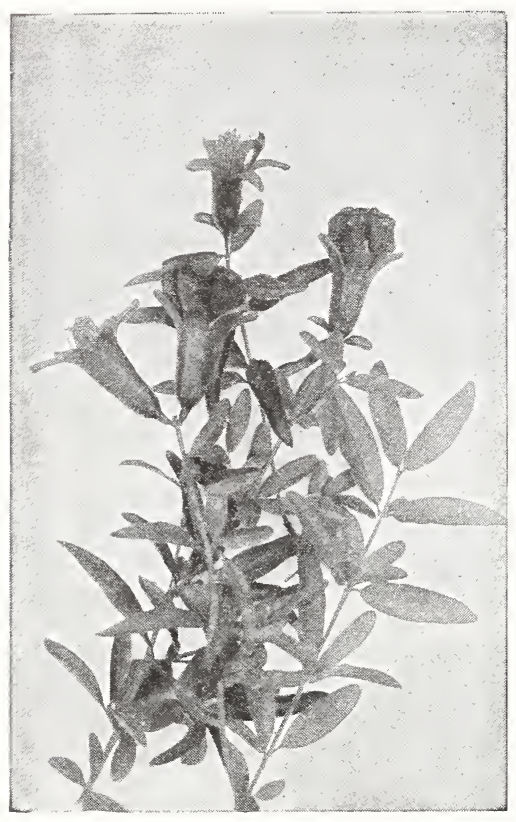

Pomegranate Blossom.

SHRUTS-Continued.

PUSSY WILLOW (Salix discolor). The beautiful glossy brown branches with fuzz covered buds are well known. To obtain a better effect, cut back after new growth comes out each year.

Each 10

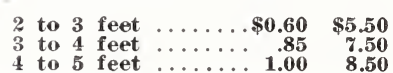

RAPHIOLEPIS Japonica (Indian Hawthorn). Low-branched shrub with thick, roundish, evergreen leaves and pinkish white flowers, sweet scented. This requires a soil of fairly heavy nature-it will not succeed on poor, thin lands.

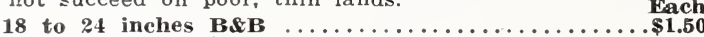

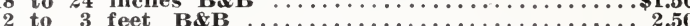

ROSEMARY (Rosmarinus Officinalis). Gray-green, sage color; low shrub, very desirable. Unexcelled for edging taller plants.

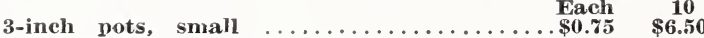

a to 3 feet, BSB ...................

SESBANIA Punicea or DAUBENTONIA. Rapid growing decidu ous shrub. Acacia-like foliage. Flowers brilliant orange-scarlet in drooping racemes. Useful for backgrounds and among large evergreens.

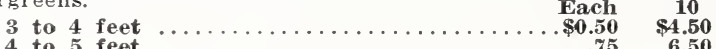

\section{SPIREA}

Dainty, graceful, flowering shrub, very desirable for informal hedges, mass or specimen planting, and for bordering the taller growing shrubs.

Van Houttei. The well known Bridal Vreath Widely grown favorite with dense foliage. White blooms in early Spring. Leaves persistent in Fall, a desirable feature. Each 10

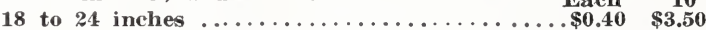

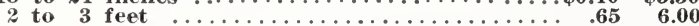

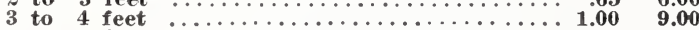

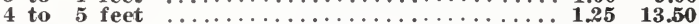

Anthony Waterer. Bright crimson, flat bloom heads. Handsome foliage. Dwarf and dense growth. Each 10

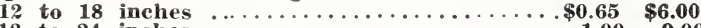

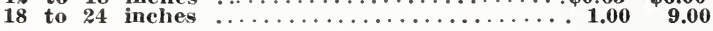

SERISSA Foetida Variegata. A low-growing, much-branched evergreen shrub, reaching a height of about 2 feet; leaves dark green; yellow margined; flowers small, white, trumpet-shaped; very desirable where a low-growing shrub is required, and very desirable for tying larger shrubs down to the ground. Fach 10

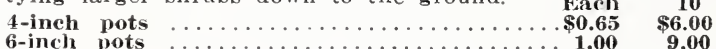

To every home owner is given the same opportunity to have a most pleasing landscape effect. Proper grouping provides for a succession of bloom from early Spring until late Fall with ample evergreen for Winter with striking berries and fruit.

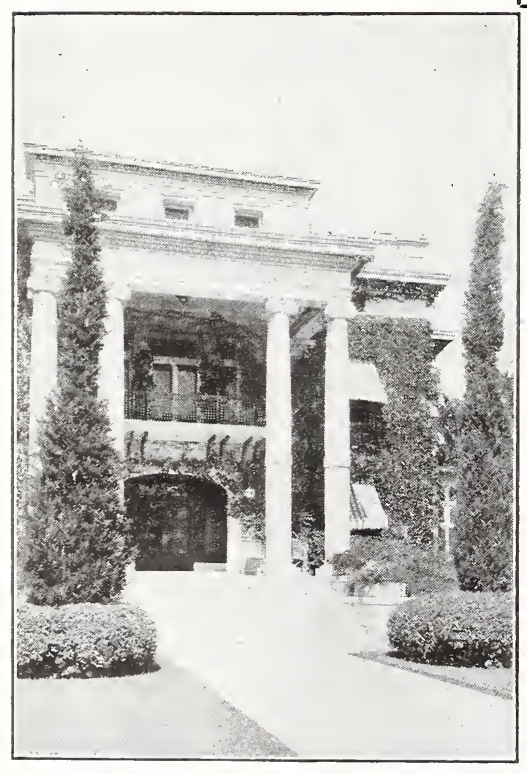

Pittosporum as We Use it for Formal Planting.

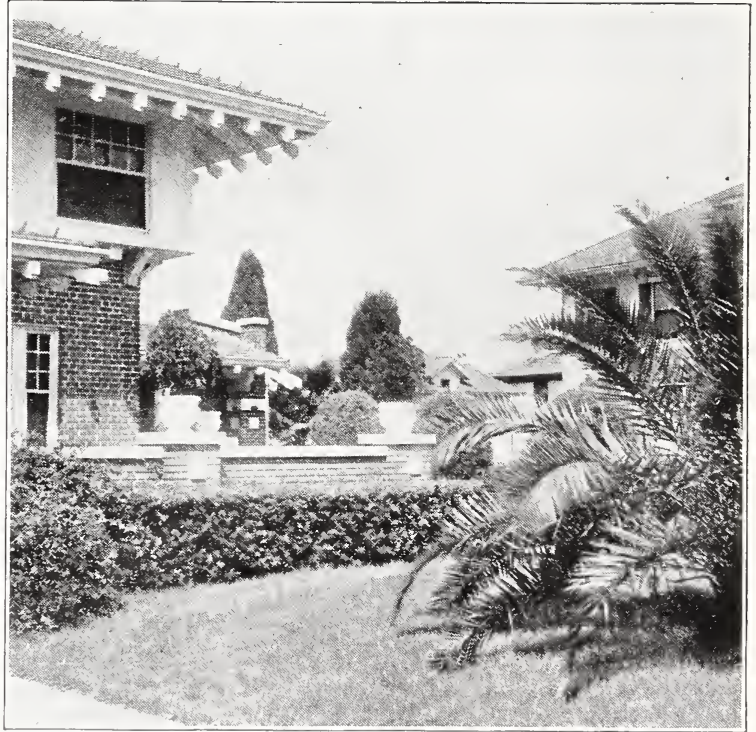

Right, Phoenix Canariensis Palm; Hedge Pittosporum.

B 8 . $R$ Wherever you find this mark B\&B it stands for Balled and Burlapped, meaning the roots are dug with firm ball of earth and securely wrapped in burlap. We always recommend such stock balled.
It assures stock living as well as immediate effect. Foliage retained. Quicker and better results. 
EVERGREEN AND DECIDUOUS SHRUBS-Continued.

SURINAM CIIERRY. An evergreen shrub with bright green, glossy leaves and producing cherry-like ribbed fruit of delightful sub-acid flavor. It makes an attractive and unique ornament for the home grounds and is a splendid hedge plant. Adapted to South Florida and similar climates.

4 -ineh pots $\ldots \ldots \ldots \ldots \ldots \ldots \ldots \ldots \ldots \ldots+\underset{\$ 0.65}{\mathbf{E a c h}} \underset{\mathbf{8 6 . 0 0}}{10}$

THUNBERGIA Erecta (Bush Morning Glory or King's Mantle). Handsome shrub for the lower South. Too tender farther north without protection from frost. Bloom inches across.

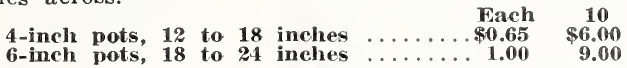

\section{VIBURNUM - Snowball}

Tinus Laurustinus. A handsome, broad-leaved, flowering shrub of rapid growth. Flowers creamy white. Very fragrant. The buds are bright red.

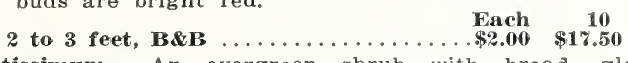

odoratissimum. An evergreen shrub with broad, glossy leaves. Flnwers white fragrant, in early spring. Grows about 8 feet high. Hardy.

Suspensum. A very fine evergreen shrub adapted to either spensum. A ver Howers white, scented and produced in sun or shade. Flowers white, scented and produced in

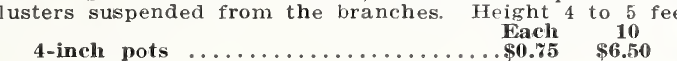

\section{WEIGELA - Diervilla}

Medium to large shrub; spreading habit; great masses of bright color in late spring.

Grandiflora. Large blossoms, brown tinge when in bud, crimson when open.

Gigantiflorum. Very large blossoms.

Hendersoni. Flowers light crimson.

Rosea. Rosy pink flowers in profusion; very early bloomer; showy.

2 to 3 feet

Each 10

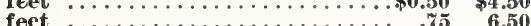

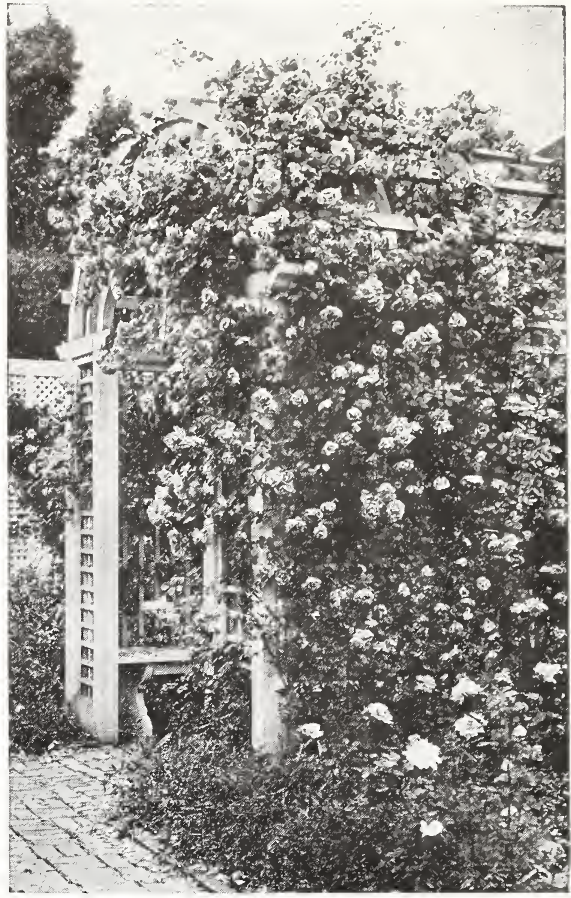

Results With Strong Growing Climbing Roses.

Messrs. C. M. Griffing \& Co.

Jacksonville, Florida.

St. Augustine, Fla

The shipment of plants, etc., (my order of the 16 th inst.) arrived this morning, and you will pardol my expression of grateful appreciation for the superb selection of plants you sent me. and for the absolutely perfect manner of packing and shipping, etc. They were quite as fresh and nice as when they left the nursery, I am sure.

I have never, in my twenty-five years or more of dealing with you received a finer lot of plants, or in better shape, and I thank vou very much indeed. They are now all carefully set out in the grounds of my new home here, and I feel that they will improve the attractiveness of my property, which is very desirably located, and in which we take a great pride.

You were most kind to include the additional plants without charge, and I am under obligation to

When your new catalogs are out I shall take pleasure in distributing three or four dozen among my friends here whom I think will be interested, if you wish to send them.

S. M. MOORE.

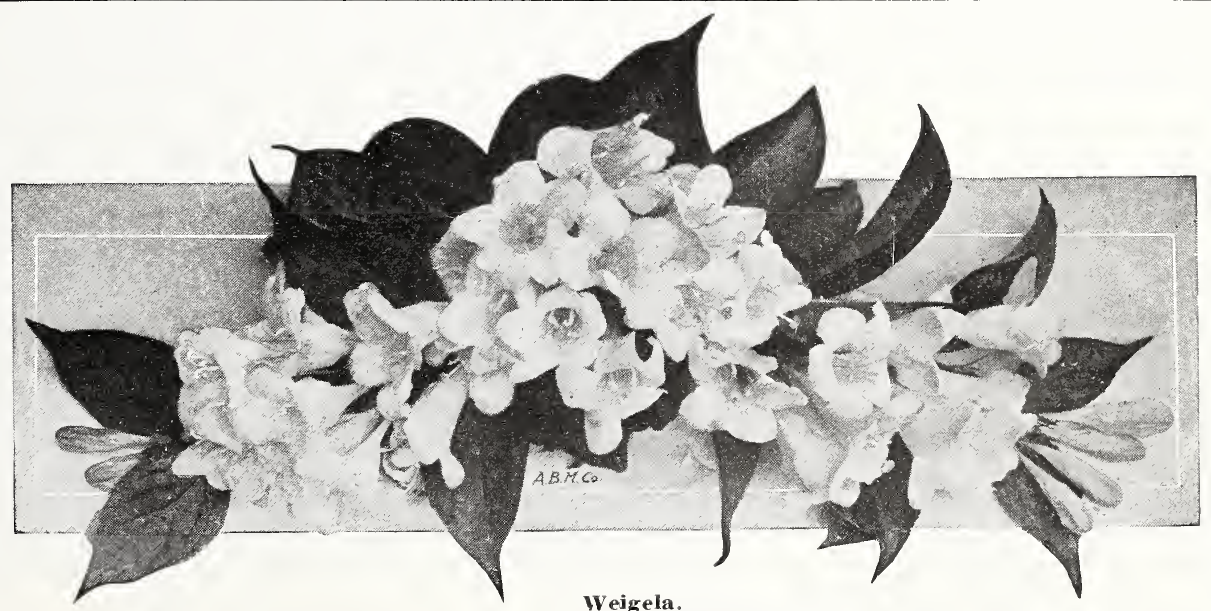

Weigela.

D D Wherever you find this mark B\&B it stands for Balled and Burlapped, meaning the roots are dug B $2 \mathrm{~B}$ with firm ball of earth and securely wrapped in burlap. We always recommend such stock balled. 


\section{Coniferous Evergreens \\ ONE OF THE FINEST AND LARGEST COLLECTIONS IN THE SOUTH}

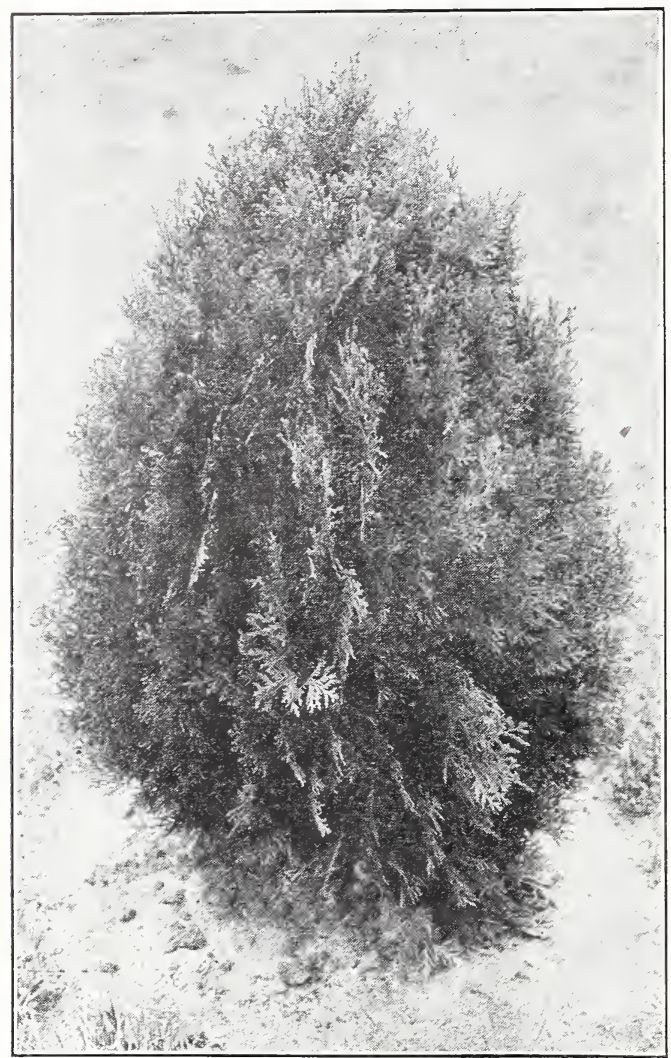

Dwarf Arbor-Vitae.

\section{Arbor-Vitaes (Biota) - Asiatic Type}

A distinctive group of evergreens. Properly placed, ther add an atmosphere of elegance to a planting not attainable with other plants. Beautiful beyond comparison, the many plants under this head are so widely varying that they are found for every purpose. For cow high dense screen planting; foundation plantings; is dense ness in masses of shrubbery-the Conifers demand attention above all classes of plants.

Hardy and thriving when established, we have found that Conifers to be successfully transplanted, must be handled B.\&B. While all permit shaping, the lower limbs should always be left close to the ground for beauty.

All Arbor-Vitaes will be balled and burlapped unless stated otherwise. We consider it best to ball and burlap Conifers, as compact, fibrous roots are not disturbed when dug with ball of dirt. Our balling methods are up-to-date, insuring your securing plants in perlasting beauty.

CAU'TION. Never lift B\&B stock by the top branches. Put both hands around ball so as not to loosen the ball any.

BAKER'S HYBRID. A fine pyramidal type which is unexcelled for its tall, columnar growth, filling a place in ornamental plantings for which there has long been a great need. A hybrid product, it has all growth, intense coloring, and distinctive appearance
PYRAMIDALIS (Green Spire-Shaped Arbor-Vitae). Of erect, symmetrical growth, attaining considerable height, forming a narrow shaft, often 20 feet while only 2 to 4 feet through. A most pleasing and contrasting effect when planted among varieties of as individual specimens

ROSEDALE. Bluish gray foliage; making a very striking plant; unlike any other Arbor-Vitae. Perobservers. Widely used for tubs and urns.

TEXANUM GLAUCA PYRAMUDALIS. Bluish green foliage, pyramidal in character of growth; similar to Biota Pyramidalis.

Prices of above

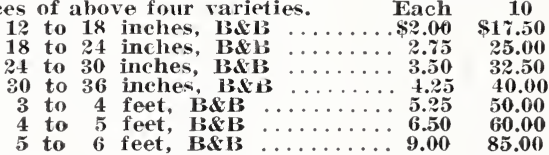

IUREA CONSPICUA. The most beautiful and artistic of all pyramidal Arbor-Vitaes. Always maintains a perfectly symmetrical pyramidal form branching perfectly symmetrical pyramidal form, branching tipe to the ground and tapering gradually lo the Fine in groups or as single specimens.

AUREA NANA (Dwarf Golden). Fine plant of dwarf habit, attaining a height of 6 to 8 feet. Compact and bushy; rich, golden-tipped foliage. Always beautuful from the little plant until maturity. Slow growth permits many uses.

BONITA. A beautiful, broad, cone-shaped Arbor-Vitae of unequalled richness, in color and perfection of form. The most attractive and useful of all varieties. Makes uniformly perfect growth, every twig being placed naturally in correct position. Slow growth makes it desirable where other shrubs would over-grow An ideal Arbor-Vitae for the finest plantings.

COMPACTA (Dwarf Green). Similar to Dwarf Golden except having bright green foliage. Very attractive.

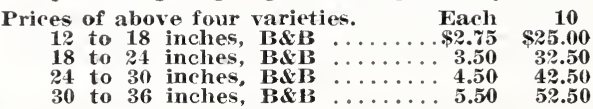

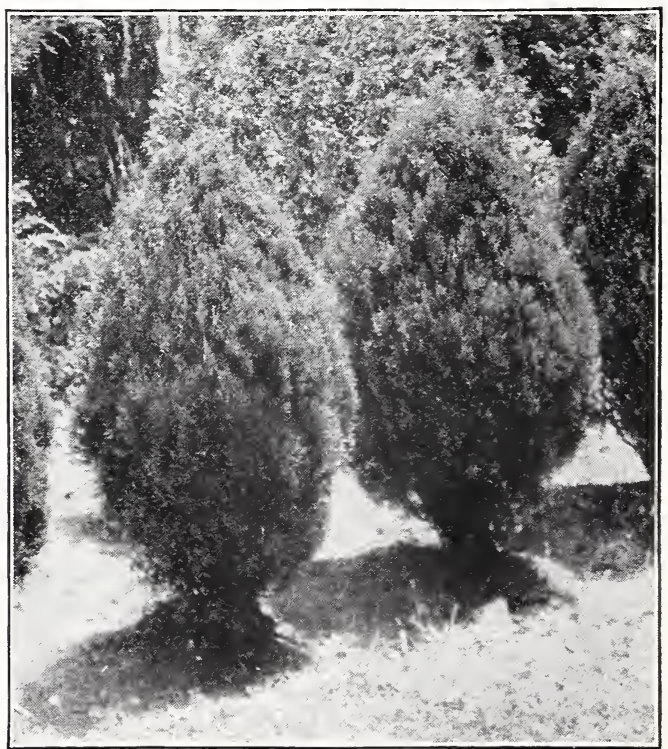

Rosedale Arbor-Vitae.

D 2 Wherever you find this mark B\&B it stands for Balled and Burlapped, meaning the roots are dug $15 \mathrm{D}$ with firm ball of earth and securely wrapped in burlap. We always recommend such stock balled. 


\section{Seedling Arbor-Vitaes}

FOR HEDGES, WINDBREAKS, SCREENS, ETC.

CHINENSIS (Chinese Arbor-Vitae). Pale golden green; upright, thrifty grower; fine for screens, hedges or windbreaks. Will grow anywhere, easy to transplant. Can be kept into compact tree by frequent careful pruning. Our stock has been pruned and is giving immediate effects. $\quad$ Each $10 \quad 100$

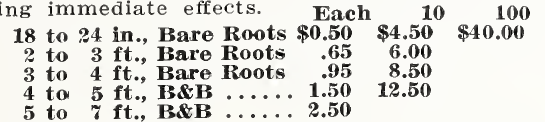

CHINENSIS COMPACTA. A type of the orientalis with compact broad, cone-shaped growth. For planting where a lower type is desired than the Pyramidal. Not so compact as the dwarf varieties. Requires some pruning, but for inexpensive planting can be used
Selected Seedlings: Each 10
18 to 24 in., Bare Roots .....\$1.00 \$9.00
24 to 30 in., Bare Roots $\ldots \ldots$ 1.25 11.50
3 to 4 ft., Bare Roots ...... 2.25 20.00

CHINENSIS PYRAMIDALIS. Upright growth. Tapers from broad base to tip. Useful in landscape plantIn foundation planting, it is valued for corners and between windows.

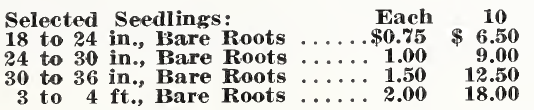

Above three varieties can be moved bare-rooted, but are better when $\mathbf{B} \& \mathbf{B}$. Double the price for B\&B stock. When used for hedges or windbreaks, just order Bare Roots.

\section{Cupressus - Cypress}

ITALIAN CYPRESS (Cupressus Sempervirens). This well known popular conifer is most desirable where a forma effect is desired. Is of compact and shaftlike habit, attaining a height of
50 feet or more.

In sizes 3 feet up to $y$ feet at $\$ 1.50$ per foot,

ITALIAN CYPRESS, Horizontal Type. Similar to Italian Cypress but more open and spreading. These make handsome specimen trees. Also fine in coniferous groups.

In sizes 3 feet up to 5 feet at $\$ 1.50$

\section{Retinispora (Chamaecy paris)}

\section{OBTUSA A slender, rapid growing} plant, rather open in habit, with cupped e of a dark green coior; usually fertile soil.

Prices of above variety.

12 to 18 in., B\&B. $\$ 2.00 \quad \$ 1 \% .50$

18 to 24 in., B\&B.. $\$ 2.75 \quad \$ 25.00$

24 to 30 in., B\&B.. $3.50 \quad 32.50$

30 to 36 in., B\&B. $4.25 \quad 40.00$

3 to 4 ft., B\&B. $5.25 \quad 50.00$

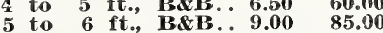

PLUMosa (Plumed Cypress). A pleasing variety of rapid growth with somewhat pendulous branches; bright green plumelike foliage; ultimate height 20 to 25 feet. Succeds
soils and situations.

PLUMOSA AUREA (Golden Plumed Cypress). One of the best, hardiest and most desirable Retinisporas. A vigorous grower and retains its golden color constantly.

PISIFERA. A hardy, rapid-growing tree with bright green, pendulous foliage, broadiy pyramidal in form; ultimate height 18
situations.
SQUARROSA VEITCHI (Veitch's Silver Cypress), A broad, pyramidal tree with fine, soft-textured ioliage of a light silvery blue-green, arranged in billowy masses like clouds of smoke; beautitul and de-
sirable. Adapted to most soils and situations, and attains a height of 15 to 18 feet.

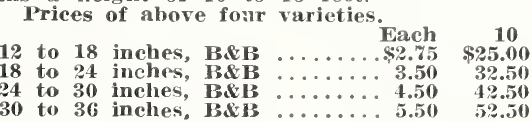

\section{Yew - Taxus}

JAPANASE YEW (Cephalotaxus Pedunculata). Small tree of compact, bushy form, glossy dark green, long, narrow leaves.

JAPANESE PLUM YEW (Cephalotaxus Drupacea) This is a rare and dwarf-growing Japanese Yew, which is almost trailing in its habit. An excellent plant for rockeries and ground covering, or where a low-spreading ef above two varieties.

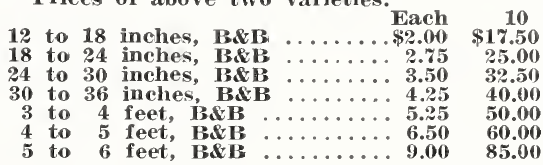

\section{Junipers}

CHINESE JUNIPER. Foliage similar to Japanese Juniper but of more compact and dwarf growth. Branches beautifully variegated golden yellow. Does not burn in summer. Very desirable.

NCENSE CEDAR (Libocedrus Decurrens). A tall, stately tree of compact, upright growth. Foliage beautiful dark green. Native of the Northwest, but thrives well in the South.

COMMUNIS. Beautiful, upright growing, feathery foliage, of varying arrangement, silvery blue in color. Is desirable specimen and splendid for color in groups and foundation planting.

Prices of above three varieties. Fach 10

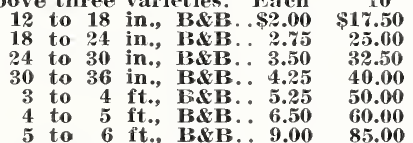
JAPANESE JUNIPER ( $J$. Sylvestris) Adapted to a great range of climate, temperature and soil. A beautiful tree; bright green foliage; pyramidal, compact growth. This type of Arbor-Vitae make no mistake in planting it.

PFITZER JUNIPER ( $J$. Pfitzeriana), Fine feathery foliage: distinct habit of growth, not of the upright, compact type but spreading and graceful.

Prices of above two varieties

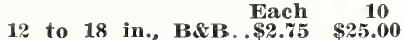

18 to 24 in., B\&B.. $\$ 3.750$ \$.5 $\$ 25.00$

24 to 30 in., B\&B. $4.50 \quad 32.50$

30 to 36 in., B\&B.. $5.50 \quad \mathbf{5 2 . 5 0}$

\section{Cedars}

CEDAR, PEODAR (Cedrus Deodara). Sometimes called Himalayan Cedar. A the Himalayan Mountains. Foliage is an attractive bluish green, the young foliage coming on the tips of small branchlets having the appearance of branchlets having the appearance of beautiful Cedars. Each 10

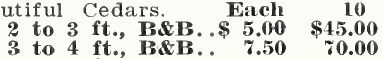

3 to 4 ft., B\&B.. $7.50 \quad 70.00$

10.00

VIRGINIANA (Red Cedar). Sturdy thrifty, strong grower. A native, well adapted for shade and ornamental purposes throughout the South. Quich grower, easily trained into formal shapes. Each 10

$$
\begin{aligned}
& 2 \text { to } 3 \mathrm{ft} \text {., B\&B. .\$ } 2.00 \quad \$ 17.50 \\
& 4 \text { to } 4 \text { ft., BNB.. } 3.50 \quad 30.00 \\
& 4 \text { to } 5 \text { ft., B\&B. . } 5.00 \quad 45.00 \\
& \text { y to } 9 \text { ft., B\&B... } 10.00
\end{aligned}
$$$$
\text { to } 9 \text { ft., B\&B. } 10.00
$$

Cupressus-Italian Cypress.

D D Wherever you find this mark B\&B it stands for Balled and Burlapped, meaning the roots are dug

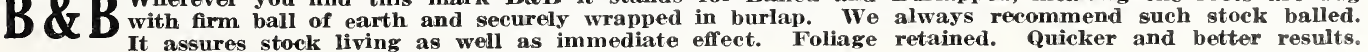




\section{BAMBOOS AND GRASSES AND MISCELLANEOUS}

There are many beautiful ornamentals which are not classed as shrubs or trees, yet have infinite value in landscape and ornamental planting. Particularly in the South do we have many beautiful plants of miscellaneous nature which ghould be generously planted for quick effect, for economy and in many instances for the atmosphere of the tropics which they produce in plantings.

\section{BAMBOOS - Bambusa}

Of all ornamental plants, none deserve more atten tion than the Bamboos. Dense plumelike foliage, enrirely evergreen, makes them ideal specimens on lawns and in parks where they are generously used. Certain varieties make beautiful screens for hiding garages

Argentea (Japanese). Attains 30 feet. Beautiful, very serviceable, Dark green, rounded form,

Argentea Striata. Similar except foliage striped with white. Height 20 feet

Falcata. Fine leaf, small-growing species. 8 to $12 \mathrm{ft}$ Verticillata. Canes striped yellow, rank grower, at -

tains 20 to 30 feet. One of the best for specimen tains 20 to 30 feet. One of the best for specim
clumps and windbreaks. Small clumps, 6 to 10 canes $\ldots \$ 1.00 \$ 9.00$ Strong clumps, 12 to 18 canes $\ldots 1.50 \quad 12.50$ Extra strong specimen clumps, 20 or more canes.........2.50 and np

\section{GRASSES}

EULALIA GRASS (Miscanthus). This beautiful group of lawn grasses is widely known and grows in al sections. Forms living fountains of green and variegated foliage. Make distinctive specimens. Grows 5 to 6 feet. Very graceful.

Univittata. Bushy clumps, dark green blades.

Variegata. Similar, white stripes lengthwise of blades. Zebrina. Similar to green, with white cross-striping. PAMPAS GRASS or FOUNTAIN GRASS (Cortaderia Sellvana). Ornamental grass. Light green foliage gracefully recurved. Makes large clumps 8 to 1 feet. In Summer sends up tall, silvery plumes which are very distinctive and beautiful. Makes fine speci men plants. In shrubbery groups it is just th right contrast. Border hedges are frequently formed with it Each 10 Small clumps, 6 to 10 canes $\ldots \$ 1.00$
Strong clumps, 12 to 18 canes $\ldots .00$
$\mathbf{9 . 5 0}$ Extra strong specimen clumps,

20 or more canes $\ldots \ldots$ and $u p$

\section{ASPIDISTRA LURIDA}

Attractive plant with wide-blade foliage of good size. Dark green color. Excellent for low foundation planting and groups in lower South.

$\begin{array}{rlr}4 \text {-inch pots, } 6 \text { to } 8 \text { leaves } \ldots . . \$ 1.25 & \$ 11.50 \\ 6 \text {-inch pots, } 10 \text { to } 12 \text { leaves } \ldots .2 .00 & 17.50\end{array}$

ACALMPHA Mosaica (Fire Dragon). Mosaic-leaved. A most gorgeous plant with curiously marked foljage showing all shades of green, yelloy and red. Very attractive planted among green-foliaged plants A fine plant, 4 to 6 feet high.

Small potted plants .......\$ 1.54 . 4.50

DRACAENA. Ornamental hothouse plant, frequently with variegated leaves. Very valuable for window and porch boxes, and for individual specimens in pots for indoor decoration. Requires warmhouse treatment and gives a very rich, tropical appearance. We have these in assorted varieties.

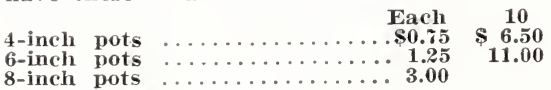

\section{SANSEVIERIA - Bow String Hemp}

Zeylanica. Herbaceous plant with stiff, erect, swordshaped leaves of dark green with silvery markings.
Beautiful plant for pot or other container. Tropical effect. Is excellent for indoor and sunroom use.

Tedium sized pot plants ............ Facli

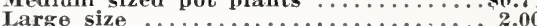

Laurenti. Resembles S. Zeylanica in habits and charac. ter of growth, except that it has a broad. strikins band of yellow down the edge of each leat, giving it a very striking appearance. Sansevierias are undoubtedly the toughest plants known for indoor undoubtedly the toughest plants known for indoor decorative purposes. They will live in water or
soil, for weeks, and in a dark room for montlis.

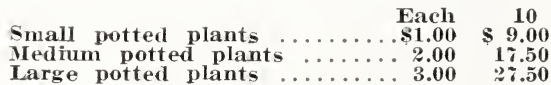

\section{AGAVES}

Americana Variegata istriped Century Plant). This is the large grotesque plant with twisted leaves, dark gleen and striped yellow on the edges, so frequently seen in the tropical garden.

Miradorensis (Dwarf Century Plant). A rare form of particular value in patio and similar situations where particular value in patio and similar situations where and compact recurving beautifull leaves are short growing about 2 feet high and sending up a flowerstalk about 12 feet high.

Neglecta (Blue Century Plant). Rich blue-green leaves, wide and gracefully recurved. The handsomest large sort in our collection, and fairly hardy. A magnificent plant, beautiful in all sizes, and fine for all decorative purposes. Fine plants, with beautiful leaves.

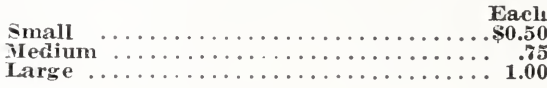

YUCCA

Aloifolia (Spanish Dagger or Bayonet). This is the spiny, upright plant typical of tropical landscapes. Good' for contrast with other plants. Frequently used to mark entrances. Each

$$
\begin{aligned}
& \text { Medium clumps } \ldots \ldots \ldots \ldots \ldots \ldots \ldots \ldots \ldots \ldots .60 \\
& \text { Iarge clumps } \ldots \ldots \ldots \ldots \ldots \ldots \ldots
\end{aligned}
$$

Filamentosa (Bear Grass). A low grower with tough leaves about a foot long. The tall flower spikes stand erect to $a$ height of 4 to 6 feet. calrying a large number of beautiful greenish whito, bel1-shated fiowers about two inches across. should have a place in every planting of any size. Tlis is hardy, all the way up to Chicago, and invaluab!e in many situations-just adding the right touch with its tall. majestic spikes of flowers resembling a candelabrum in form.

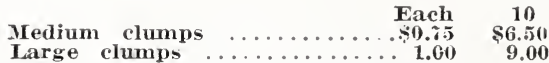

\section{CANNAS}

Good for cheap, quick effect. When used in this way, plant informally as a border for shrubs until more permanent plants attain fuil growth.

URCRAEA Lindeni. A splendid, variegated agave broad stripes of white show off very clearly. Rare new plant of recent acquisition; valuable as a house plant.

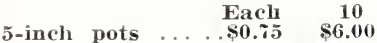

\section{LILIES}

Crinum. Wide blade leaf, averaging to 3 feet long. Blooms late Summer and tarly Fall, producing long stos soms. Hardy. Multiplies rapidly.

Bulbs

$10 \quad 100$ $\$ 2.00 \$ 15.00$

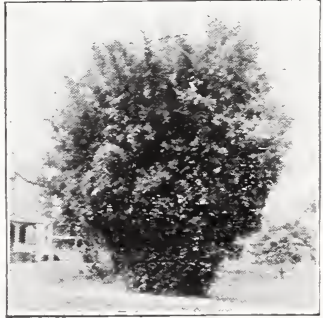

Bamboo.
King Ifumbert. The greatest Canna ever offered; bronze foliage, crowned with immense heads of orchid-like flowers; color velvety orange-scarlet.

Indiana. Green foliage; color soft orange, lightened by soft flakes of gold.

Wyoming. Bronze foliage. Orange flowers; resembles Indiana.

Pennsylvania. Soft dark scarlet; green foliage.

$\begin{array}{rr}10 & 100\end{array}$ 


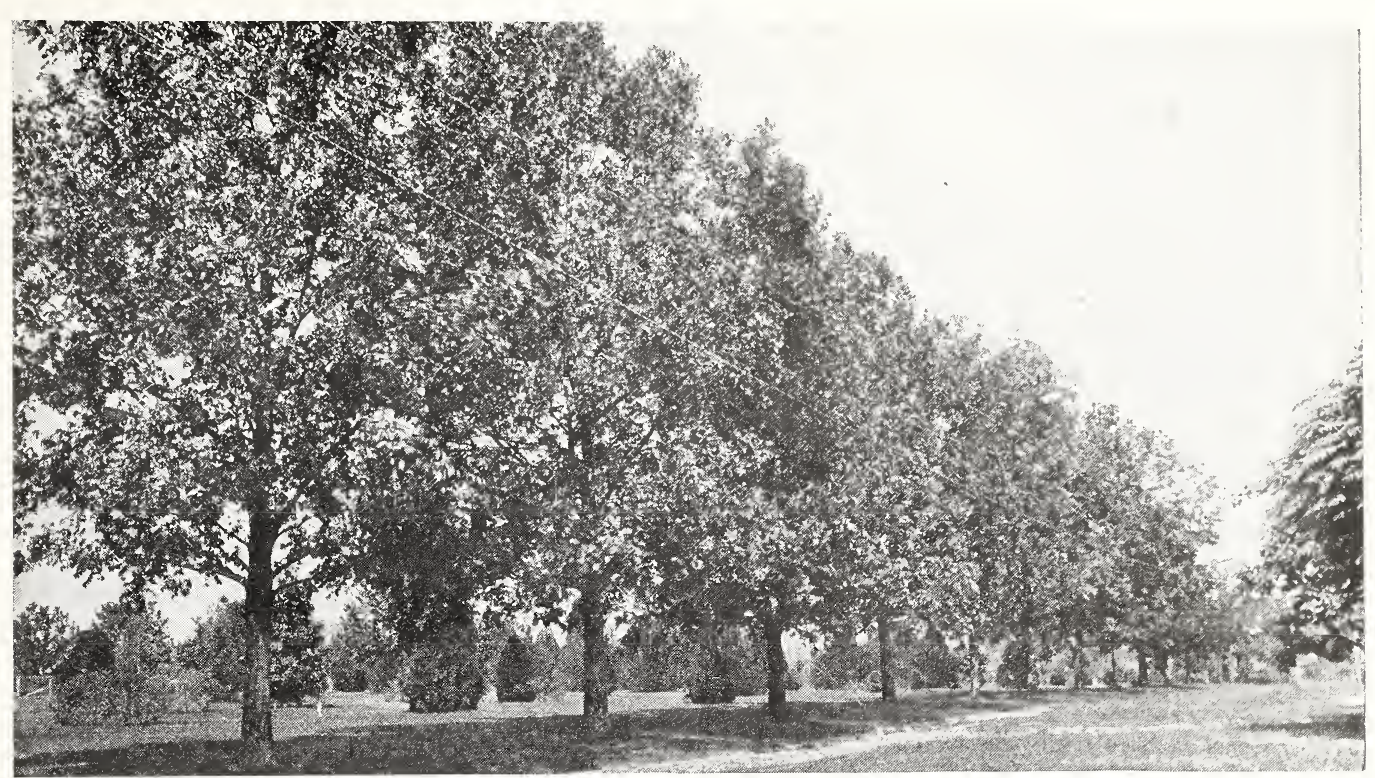

Pecans as the Beautiful and Useful Avenue Tree Bordering Our Nursery Grounds.

\section{Shade and Ornamental Trees}

In this group we have listed the best medlum and large growing trees suitable for shade and street planting or for ornamental value and adaptability to general landscape work. Not only necessary for beauty and com fort, shade trees are the most advantageous me GRIFTING'S RIO GRANDE ASH (Fraxinus Velutina) A most beautiful shade tree for either street or lawn purposes. Clean growth, no leaf-littered lawn straight, covered with grayish white, smooth bark. Foliage dark green, very glossy. Remains on tree young leaves in Spring. Young trees practically evergrean in coastal sections. Beautiful immediately after planting. Safe for coastal plantings where there are occasional salt water inundations. Plantings alvays receive attention by visitors and have met with the universal approval of our trade. Recommended for extensive planting in Gulf states. A rapid grower. Each 10

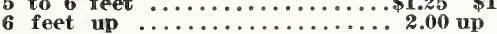

AUSTRALIAN PINE or CASUARINA. Not a true Pine, having no pitch or resin. Beautiful, rapid-growing trees with odd follage and branching resembling the native Pines. Adapts itself to almost any soil. Will not only endure salt spray but will thrive on the driest and poorest sandy ridge, miles inland. One of the best trees we know of for sub-divisions where soil and cultural conditions are not good and tree, giving quick results; also good as specimens and for group plantings.

Cunninghamiani. This variety has stood a temperature of 20 degrees above in Florida in 1918 and is said by Department of Agriculture officials to be immune to a minimum of 10 degrees.

Stricta. Extensively used in California. A prominent nurseryman there writes- "it is our opinion that they will stand a temperature as low as 10 degrees Fahrenheit, although they may stand lower temperatures."
Potted plants, 2 to 3 feet ......\$1.25 $\$ 10.00$

Potted plants, 2 to 3 feet $\ldots \ldots \ldots \$ 1.25 \quad \$ 10.00$

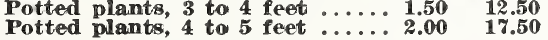

AUSTRALIAN SILK OAK (Grevillea Robusta). An attractive tree of fernlike follage. A splendid shade or ornamental treo and very desirable for pot culture.

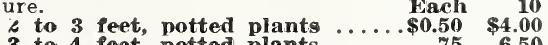

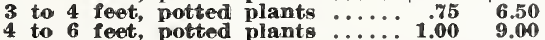

CAMPHOR 'TREE (Cinnamomum Camphora) splendid shade tree for the lawn, street or for park planting. Dense, bright green, glossy follage all the year. A few leaves turning red in Autumn making an exceptionally attractive sight. Clean growing and very symmetrical. No leaves to rake up and the natural compact elliptical form avoids necessity for trimming. Camphors are grown in bush and tree form. Be sure to specify which you want.

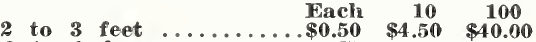

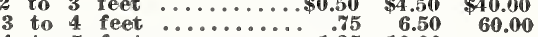

$$
\begin{aligned}
& 4 \text { to } 5 \text { feet } \ldots \ldots \ldots \ldots \ldots \text { 1.25 } 10.00 \\
& \text { B\&B at double above prices. }
\end{aligned}
$$

\section{Eucalyptus - Australian Gum}

Very fast growing evergreen trees, highly desirable where hardy

Robusta. Symmetrical branching, well adapted to avenue planting.

Rudis. A hardy variety much grown in Texas. Stands drought better than most varieties. A beautifu avenue tree; young growth of deep copper color.

Rostrata. Tall, hardy, rapid-growing tree

Tereticornis. Valued for posts and timber. Strong grower and quite hardy.

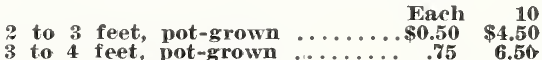

$$
\begin{aligned}
& \begin{array}{llllll}
3 & \text { to } & 4 & \text { feet, pot-grown } \\
4 & \text { to } 5 & 5 & \text { feet, pot-grown } \ldots \ldots \ldots & .75 & \mathbf{6 . 5 0} \\
& & &
\end{array}
\end{aligned}
$$

\section{Holly - Ilex}

Opaca (American Christmas Holly). Grows to 20 leet tall. Handsome tree and valuable for Christmas decoration. Red berries.

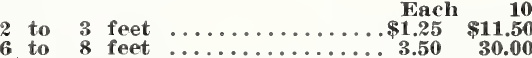

$$
\begin{aligned}
& 8 \text { to } 10 \text { feet } \begin{array}{c}
\text { B\&B at double above prices. } \\
\text {. }
\end{array}
\end{aligned}
$$

Myrtifolia (Myrtle-leaved Holly). Handsome small tree of Holly family with small oblong bright gree leaves, handsome red berries in Fall and Winter.

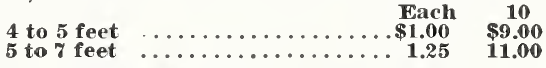
B\&B at double above prices.

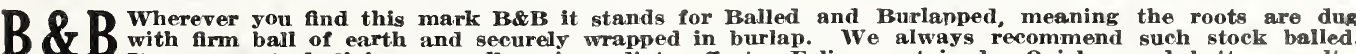
It assures stock living as well as immediato effect. Foliage retained. Quicker and better results. 


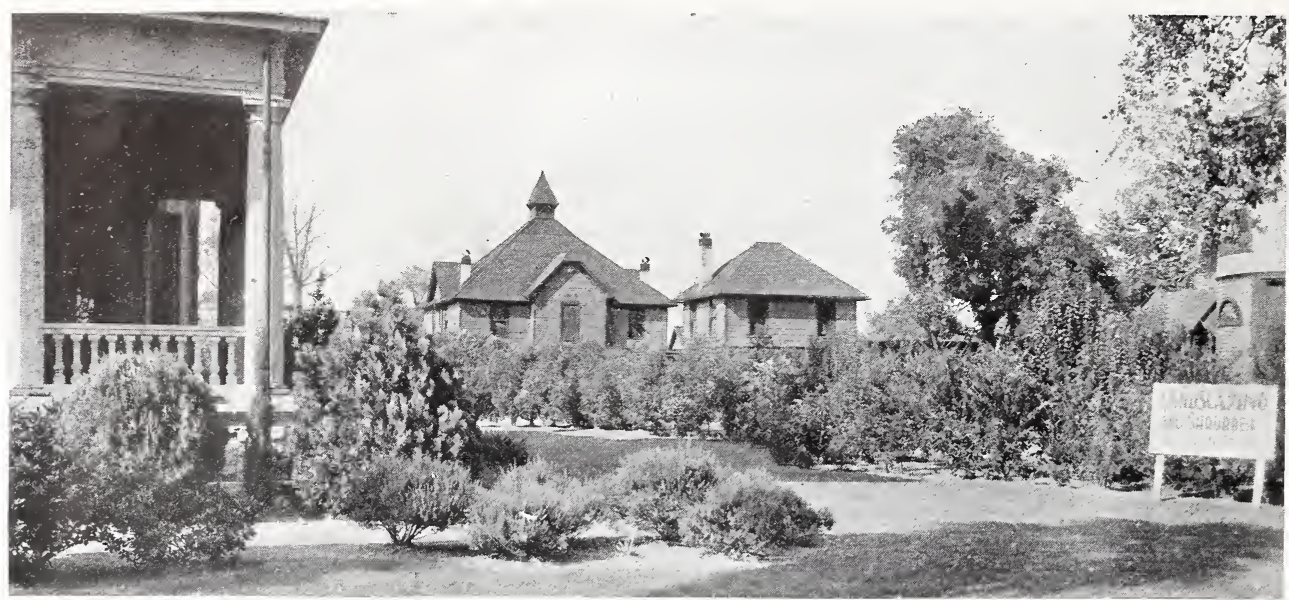

In this Planting, Just Completed, there were used Myrtus Communis, Arbor-Vitae Elegantissima and Compacta, Pittosporum, Several Varieties of Ligustrum, Nandina, Photinia,

\section{Jacaranda Mimosaefolia}

\section{(St. Brazil)}

While not especially adapted for street work, this undoubtedly is one of the most lovely trees for South Florida planting. The foliage is very finely cut, almost fernlike, symmetrical and elegant. The large panicles, each bearing 40 to 90 flowers of lavender-blue, come the tree is a cloud of biue. Each 10

\section{S-inch pots}

Prunus Caroliniana (Southern or Cherry or Wild Peach). Considered among the best broad-leaved evergreen shade trees for Southern planting. Suited to any place where a shade tree is needed. Can be trimmed to any desired size.

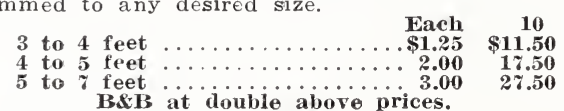

\section{Magnolias}

Beautiful broad-leaf ornamental trees.

Grandiflora. The broad-leaf evergreen giant of the forest. Immense white blossoms. Well known throughout the South. Beautiful from small tree to maturity.

Gauca (Sweet or White Bay). Handsome native evergreen. Leaves green and lustrous on upper surface,
pale or pearly white beneath. Fragrant, creamypale or pearly white beneath. Fragrant, cream

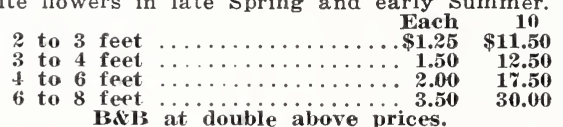

\section{Oaks}

Virginiana (Live Oak). One of the finest and most popular Evergreen shade and ornamental trees. Contrary to the general idea, it is a comparatively quick grower, attains immense size, is symmetrical in shape, entirely evergreen, has dark, glossy green foliage and is a very clean tree for lawn and avenue planting.

3 to 4 feet

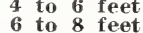

urifolia (Laurel Oak). Tall-growing tree, to 60 feet or more. Comparatively slender branches round-topped head, foliage glossy; almost evergreen A most excellent street tree.

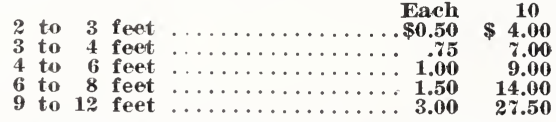

\section{Other Shade and Ornamental Trees}

All other varieties of our Shade and Ornamental trees are grouped under the following prices. Sizes of each in stock follow description: Each 10

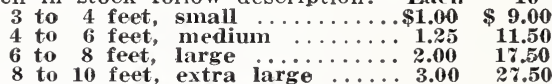

ALBIZZIA Julibrissin. Small flat-top spreading tree, compound leaves; pink flowers in showy large bunches. Fast growing. Sizes: 2 to 3 feet; 3 to 4 feet; 4 to 5 feet.

ASH, Green (Fraxinus Viridis). Rapid growing, symmetrical hardwood tree. All sizes.

DoGIVOOD (Cornus Florida). Handsome small shade tree producing a mass of white flowers in early Spring. 3 to 4 and 4 to 5 feet.

FIM, White (Ulmus Americana). Famous in the North and quite well adapted to Southern planting. All sizes.

HACKBERRY (Celtis Sinensis). Handsome small tree. Foliage beautiful for long season. Almost evergreen. $S$ to 10 feet only.

MAPLE, Soft. A thrifty, strong-growing Maple adapted to southern planting. All sizes to 4 to 5 feet.

POPLAR, Carolina. A rapid-growing symmetrical, large shade tree. All sizes.

POPLAR. Lombardy (Populus Italica). One of the most striking and picturesque of trees. Valuable for lending distinction to massed plantings. lndispensable in formal landscape work. All sizes.

POPLAR. Simon (Populus Simoni). A tall, rapidgrowing, small-leaved, deciduous, Chinese Poplar of upright, pyramidal habit, more beautiful than Lombardy and better adapted to the lower South. Meyer's introduction. 3 to 4 feet and 4 to 5 feet.

REDBUD (Cercis Canadensis). Very ornamental small tree, producing a profusion of delicate reddishpurple flowers early in spring before foliage appears. All sizes.

SYCAMIORE (Oriental Plane). A desirable shade tree where immediate effect is wanted. All sizes.

TALLOW, Chinese (Sapium sebiferum). Cleanest of deciduous trees. Compact, dense head of small bright green leaves. A beautiful shade tree and very desirable for streets or avenues, anywhere in the South. Highly desirable for any purpose. Attains 40 feet. In mid-Summer and late Fall, when so many trees have yellow and brown falling leaves, the Tallow is beautifully fresh and green. Highly recommended. All sizes to 5 to 7 feet.

TEXAS UMBRELLA (Melia). Too well known to need description. 2 to 3 feet, 3 to 4 leet, 4 to 5 feet, 


\section{Hedge Plants}

There are many widely different varieties of plants which malke beautiful hedges and the height and form of each hedge can be sheared to the owner's taste and the needs of the house.

AMOOR RIVER PRIVET ( $L$. Amurense). Most popu. lar hedge for the South. Very beautiful, practically evergreen, dense in growth, very compact and establishes a very good hedge in one year. Hardy and adapted to general planting. Permits shearing to
any height or shape.

CALIFORNIA PRIVET. Thick, green foliage; nearly Price of Amoor River and California Privet:

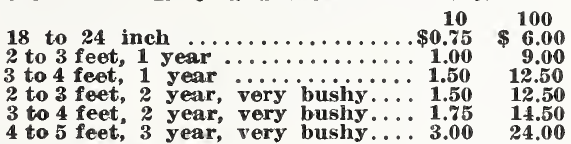

BAMBOO HEDGE. Bamboo can be sheared into round or oval shaped hedges with striking beauty. Entirely evergreen, very dense and compact. Can be kept low Untrimmed it makes a hedge of graceful teathery cut back on Hedge Plants.

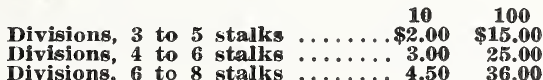

CAMPHOR HEDGE (Cinnamomum Camphora). Camphor as a hedge needs no introduction to those who have seen clipped or untrimmed hedges. The same color hedges. The same color beauty is had in the hedge, enhanced by its sedge, enhanced by its Will reach ten feet or more if never trimmed. Requires little attention.

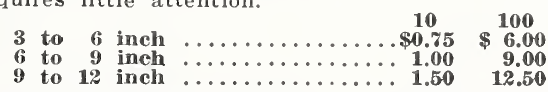

OTHER DESIRABLE HEDGE OR BORDER PLANTS. Chinese Arbor-Vitae, All Ligustrums; Laurel; OleMyrtle; Pampas Grass; Pittosporum; Althea: Crape index)

\section{CHERRY IAUREL.}

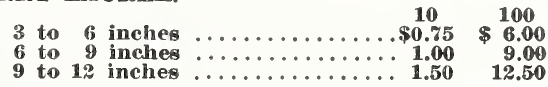

\section{Vines}

Beautiful, artistic vines quickly make beauty spots of each nook and corner, hide all unsightly views, and surround the home with colorful, fragrant blossoms.

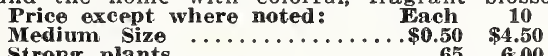
Strong plants $\ldots \ldots \ldots \ldots \ldots \ldots \ldots \ldots .6 \%$.65 $\mathbf{6 . 0 0}$ Extra strong plants $\ldots \ldots \ldots \ldots \ldots \ldots$ 1.00 9.00

ALLAMANDA Hendersoni (Golden Trumpet). One of the most gorgeous tropical plants grown in Florida: may be trained either as a vine or shrub, and will grow well up into the southern edge of our Gulf States, as the loss of top by frost is very quickly remedied by a few weeks of Spring weather. Glossy green, broad leaves; flowers constantly produced, four to five inches across, pure golden yellow. Makes a charming combination with strong blue tones.

A. Williamsi (Canary Flower). This is simflar to preceding species except in size of flower, which is only about three inches across, and sometimes a trifle fragrant. Exceedingly floriferous. 35c each;

A NTIGONON Leptopus. "Rosa de Montana," "Coral Vine," "Queen's Wreath," and many other names describing its beauty are synonyms for this beautiful, rapid-growing climber from Mexico. Attains great rapid-growing climber from Mexico. Attains great leaves light green, heart-shaped.

\section{Honeysuckle - Lonicera} Chinese. A showy variety with purplish evergreen
foliage, changing to greener shades at maturity. White flowers.

Hall's Japan. Glossy, evergreen follage. Flowers

white, changing to yellow.
Golden Netted. Leaves netted with yellow. Evergreen.

Bougainvillea - Japan Paper Flower

Crimson Lake. Best of the new ones; a rich glowing red, later overcast with purple shades. Very rank

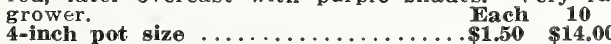
4-inch pot size $\ldots \ldots \ldots \ldots \ldots \ldots \ldots \ldots \ldots \mathbf{\$ 1 . 5 0} \mathbf{\$ 1 4 . 0 0}$

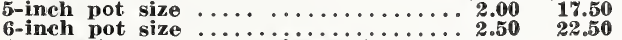
4 to 5 feet, large specimens in boxes

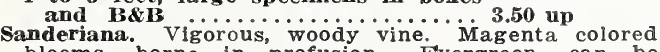
blooms, borne in profusion. Eivergreen, can be trained as shrubs.

\section{Clematis}

Paniculata. Flowers white, star-shaped; produced during Summer and Fall. In addition to its flowers, follage is very handsome.

\section{Ivy}

Thglish Ivy (Hedera Helix). Shiny evergreen leaves. Extensively used for covering trunks of palms, trees,

walls or pergolas.
Boston or Japan Ivy (Ampelopsis Veitchi). Glossy greon leaves, excellent for covering stone, concrete, wood or brick walls.

Virginia Creeper, Improved (Ampelopsis Engelmann!). For the same uses, but has finer cut leaves than the Boston Ivy, shorter jolnts and more rapid growth.

\section{Jasmines}

Carolina Yellow Jasmine (Gelsemium Sempervirens). A very graceful, slender, rapid-growing natlve vine with dark green leaves; yellow flowers produced in abundance in early spring. Most fragrant.

Star Jasmine (Rhynchospermum Jasminoldes). Strong growing, twining vines, glossy leaves; covered in Spring with very fragrant starry white flowers in clusters. Large size only, $\$ \mathbf{1 . 0 0}$ each

Jasninum Pubescens. An evergreen vine or rambling shrub, with beautiful green follage and showy, white, shrub, with beautiful green follage and showy, white,
star-shaped flowers. It may also be grown in shrub form. Quite hardy and a satisfactory vine.

J. Sambac, Grand Duke. A very double-flowered Jasmine. The blooms are frequiently $21 / 2$ inches wide and intensely fragrant. Follage is dark green and and intensely fragrant. Foliage is dark green and

J. Sambac, Maid of Orleans. Semi-double flowers, 1 1 to two inches wide, very fragrant; constantly in

flower. Fine. Variegated (Rhynchospermum Jasminoides Variegata). Variegated varlety of the pre-

\section{Climbing Rubber - Ficus Repens}

The most perfect creeper. Has small, round or oval glossy leaves, short stem. A very tenacious and beautiful climber for covering any kind of masonry.

\section{Wisteria}

The ever popular hardy vine for pergolas and porches. Long, drooping clusters of fragrant bloom. Varieties, blue and white.

\section{Bignonia - Trumpet Flower}

Radicans Tecoma (Hardy Orange Trumpet). Brilliant orange-red flowers produced throughout the Summer. Dark green leaves. A rank climber.

Speciosa (Blue or Purple Trumpet). Evergreen hardy vine. Flowers in great clusters.

Venusta (Flameflower). A grand, tropical trumpet creeper, growing on houses, high trellises or trees up to 70 feet or more and producing countless tubular flowers of a bright orange-red.

\section{Kudzu Vine}

Remarkably vigorous vine frequently producing stems 40 to 60 feet long in a single season-a veritable "Jack-and-the-Beanstalk." Adapted for arbors, verandas, and where quick results are wanted. We recommend this as a permanent leguminous cover crop $\$ 8$ per $100 ; \$ 60$ per 1000 .

\section{Euonymus}

Radicans Acutus. A splendid new introduction with small follage and of vigorous growth when established. Much better than the old E. Radicans type. It does well in a variety of soils and clings to any support unaided or will make a good ground cover
if not in dense shade. This is particularly useful for covering palm trunks. 


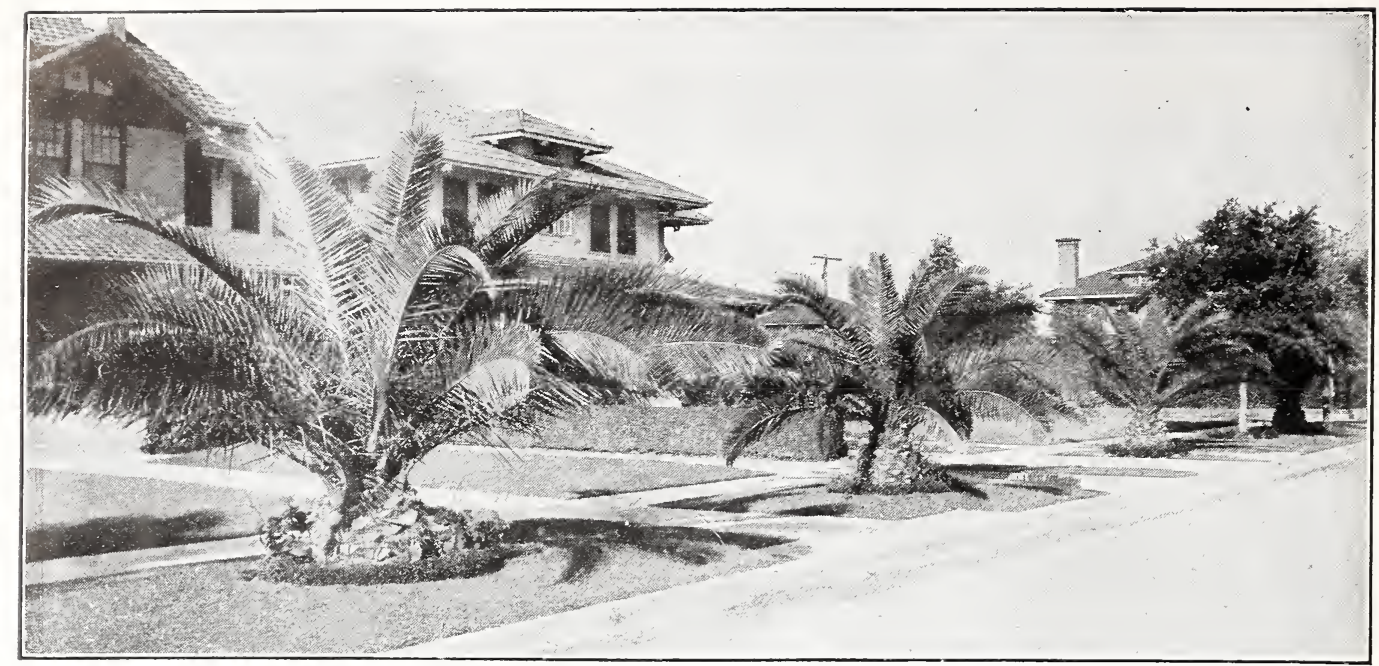

Nothing More Beautiful Than Stately Phoenix Canariensis Palms for Streets With Wide Parking Spaces.

\section{Palms for Outdoor Planting BaLELDAND}

The hardy Palms we list are safe for outside planting from the Coast back about 150 miles and should be extensively planted in the home grounds, parks and streets, and there is nothing that gives a more inviting, tropical effect to our northern visitors than to come where they may be among the waving Palms and enjoy the mild Winters of the southern climate.

CHAMAEROPS EXCELSA (Windmill Palm). Very hardy fan-leaf variety of dwarf habit. Trunk slender, erect, covered with brown filament. Well adapted to northern portion of the Palm Belt. Beautiful head of rich green leaves. 1 to 2 feet B\&B .........\$2.00 $\mathbf{\$ 1 5 . 0 0}$

Cocos AUSTRALIS (Pindo Palm). The hardy Cocos. Exceptionally graceful, long, recurved leaves, pinnate, of impressive, silvery green color. Fruit edible: trunk erect. Beautiful specimens. Very hardy. more so than Phoenix or Washingtonia types.

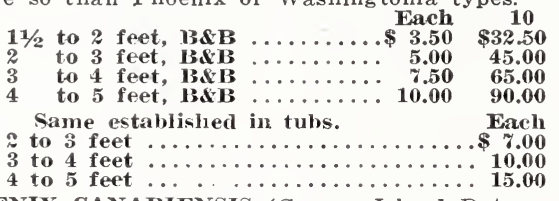

PHOENIX CANARIENSIS (Canary Island Date Palm). Large, graceful, recurved leaves, growth remarkably rapid, general appearance very dark green, beautiful stately trunks;

$11 / 2$ to 2 ft., B.SB $\$ 2.00 \quad \$ 1 \% .50 \quad \$ 150.00$

2 to 3 ft., B.SB $3.50 \quad 30.00 \quad 275.00$

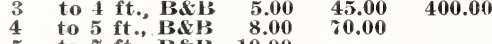

5 to $\%$ ft., B\&B 10.00

Same established in tubs. Each

2 to 3 feet ............. 4.50

3 to 4 feet $\ldots \ldots \ldots \ldots \ldots \ldots \ldots 6.6 \%$

$\mathbf{4}$ to 5 feet $\ldots \ldots \ldots \ldots \ldots \cdots \cdots, \mathbf{9 . 0 0}$

WASHINGTONIA ROBUSTA. Leaves large, deep green, not deeply serrated, short and somewhat recurved leaf stems, compact head,

leaves never turn yellow; tallest growing.

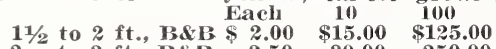

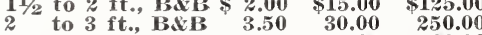

$$
\begin{aligned}
& 3 \text { to } 4 \text { ft., B.SB } \quad \mathbf{5 . 0 0} \quad \mathbf{4 5 . 0 0} \quad \mathbf{4 0 0 . 0 0} \\
& 4 \text { to } 5 \mathrm{ft} ., \text { BNB } 8.00 \quad 70.00 \\
& \text { to } 7 \mathrm{ft} ., \quad B \& B \quad 10.00 \\
& \text { Each } \\
& 2 \text { to } 3 \text { feet } \\
& 3 \text { to } 4 \text { feet } \\
& 4 \text { to } 5 \text { fect } \ldots \ldots \ldots \ldots \ldots \ldots \ldots .9 .00
\end{aligned}
$$

CYCAS REVOLUTA (Sago Palm). A palmlike Cycad reaching a height of 3 to 4 feet, with cycad, reaching a height of 3 to 4 feet, with outward from the center very hardy; grows outward from the center, very hardy; grows the Gulf Coast. Young plants have but the Gulf Coast. Young plants have but a single stem; old ones are often branched. We

$$
\begin{gathered}
\text { 4-inch pots } \\
\text { 6-inch pots } \ldots \ldots \ldots \ldots \ldots \$ \text {..50 }
\end{gathered}
$$

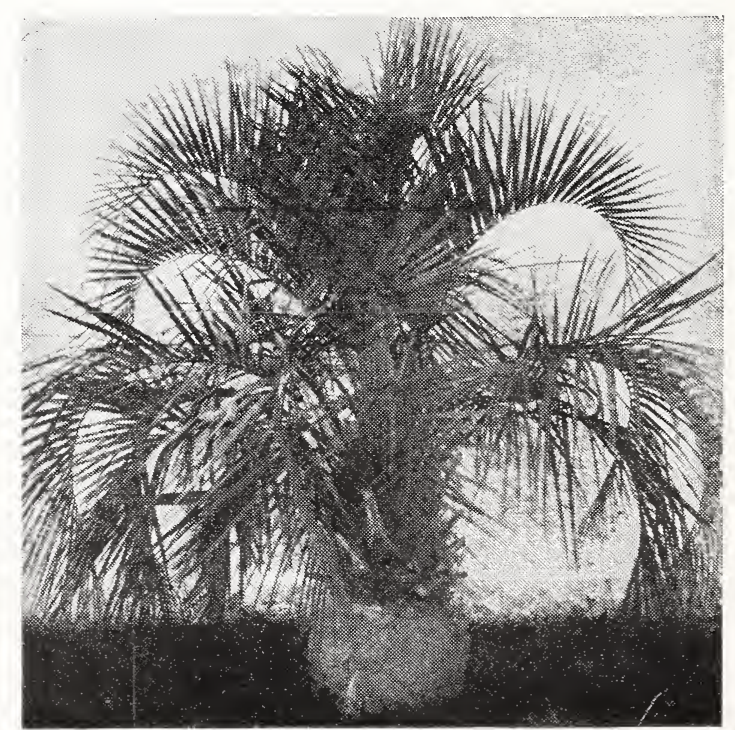

Cocos Australis Palm (Balled).

For immediate effect we advise ordering Palms established in tubs. Grown in this manner, they retain all of their foliage after transplanting. 


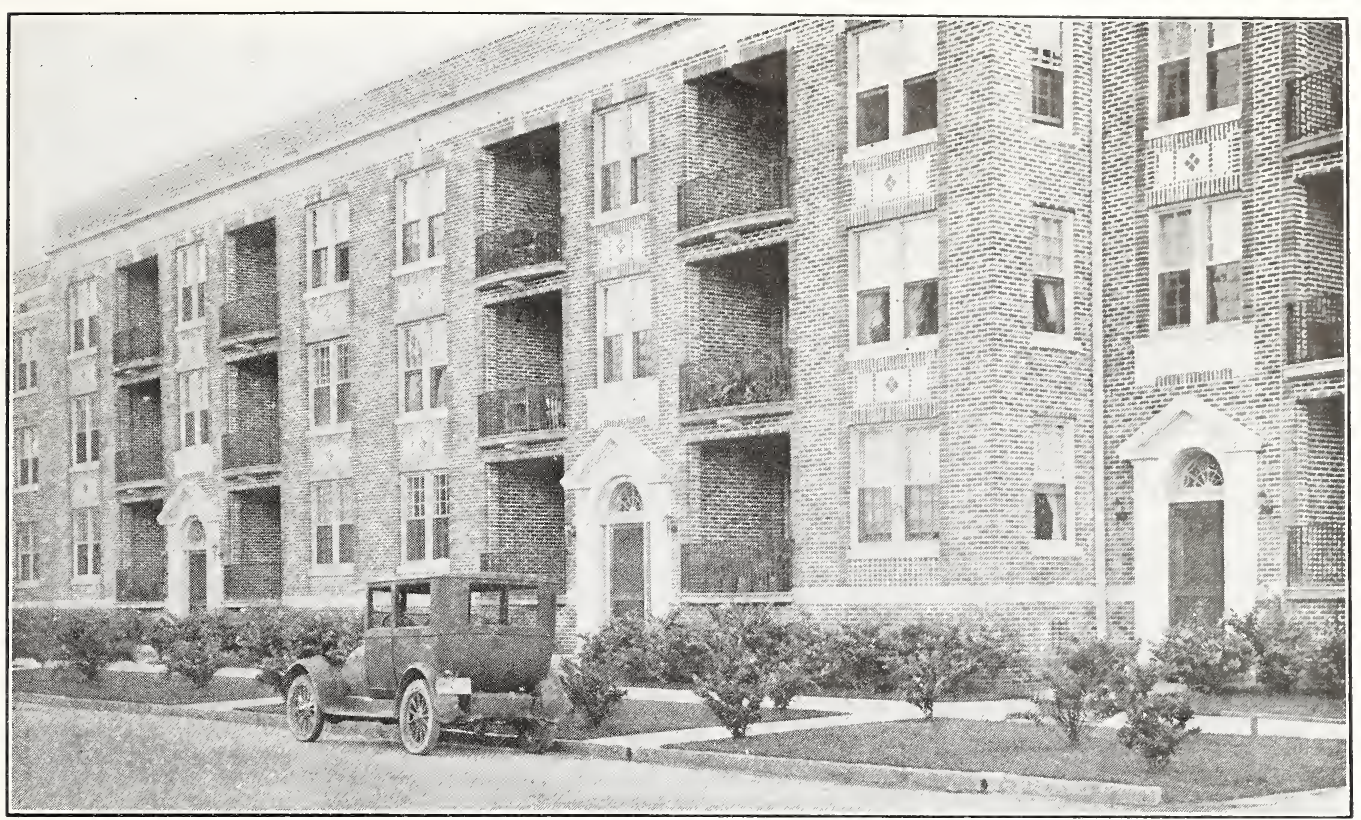

New Apartment House Showing Immediate Effect of Planting.

\section{Apartments and Hotels}

Recent years have brought about a change of living and particularly can we note the great number of people selecting apartments or hotels for their homes. This brings a need in the way of encouraging our hotel and apartment house own ers to take an interest in the exterior appearance of these places. Besides, there is some satisfaction derived in feeling you have made the premises as home-like as possible. Please note the picture above of a Jacksonville apartment house. The owner of this fine property claims that this planting added considerably to its value. Think of the pride the occupants feel in living in an atmosphere that is cheerful.

Write us for prices and plan of arrangement. It will pay you well in the end.

\section{Business Houses}

It has often been said that big corporations and large business concerns were not interested in any beautification plan. The photo shown below refutes this statement, as this is just one example of many business buildings planted with handsorne flowering shrubs and palms. Think of the effect this nas on the passerby and how it may the effect this nas on the passerby and how it may influence him in choosing your establishment to
trade with. Then, another strong factor is the pleasing effect it has on those in your em. ploy, assuring you their best services. The whole immediate surroundings profit from such a planting and in time will become so contagious that others will follow in your welfare work. we sucgest starting with a few well chosen plants or palms. You will soon appreciate its tremend. ous value.

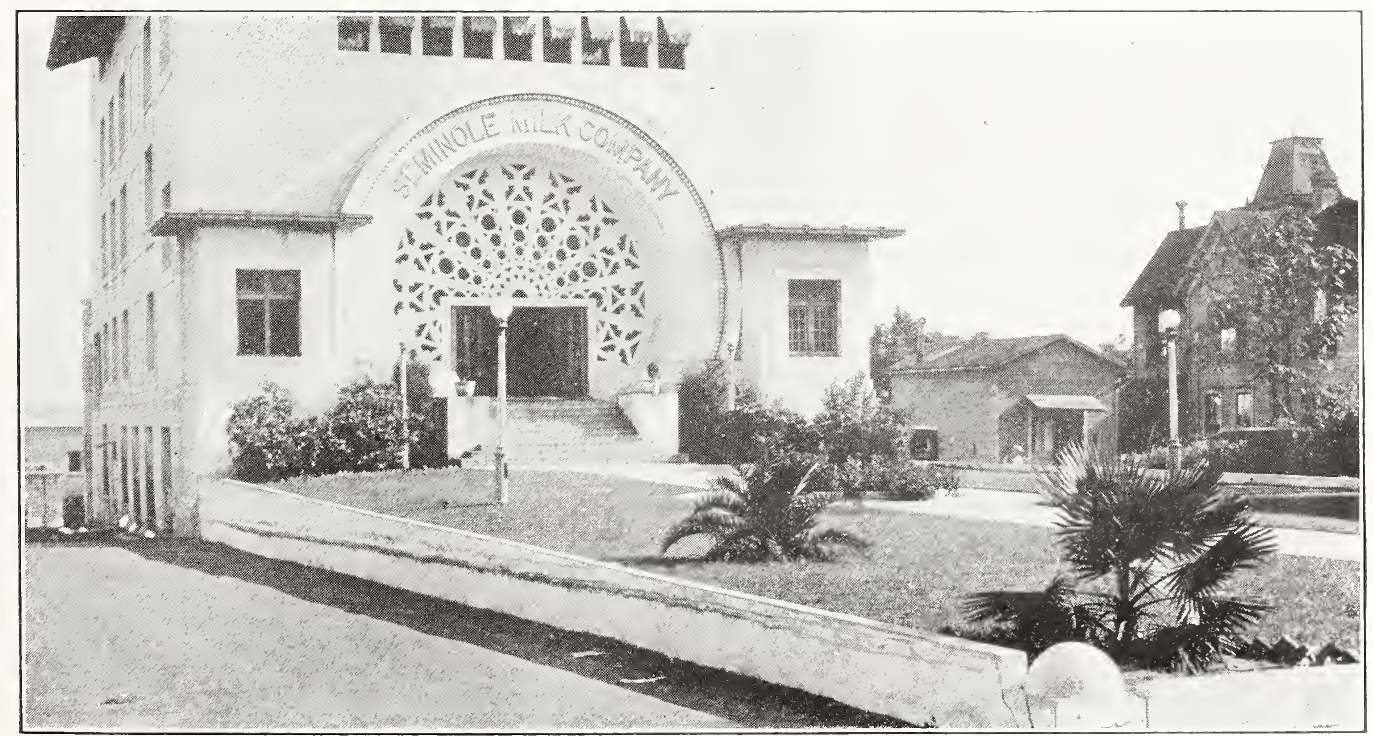




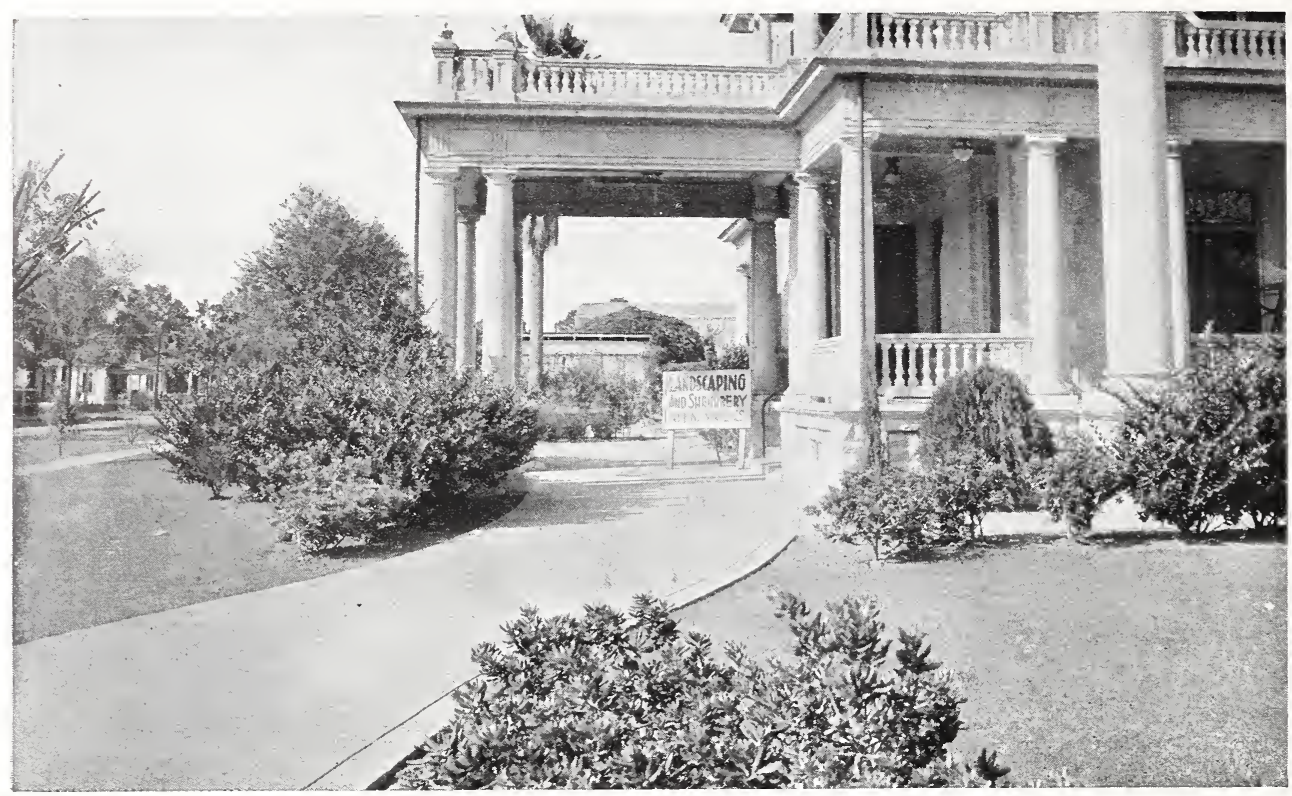

A Planting of Large Specimens, Mostly Ligustrums, Pittosporum and Conifers.

\section{Advisory Department}

Valuable Information for Those Who Are Interested in Home Grounds and Orchards

RIFFING'S Letter Aid Service is offered to all our friends. Through $\mathcal{T}$ it we are enabled to give much the same information as is rendered through a personal call. If there are specific questions you want answered and problems you need horticultural advice about, write us in full detail and we will advise and give information without charge.

The purpose of this book is to create a desire in the hearts of southern people to take advantage of the possibilities they have within their grasp to make OUR SOUTHLAND A REAL PLACE OF BEAUTY.

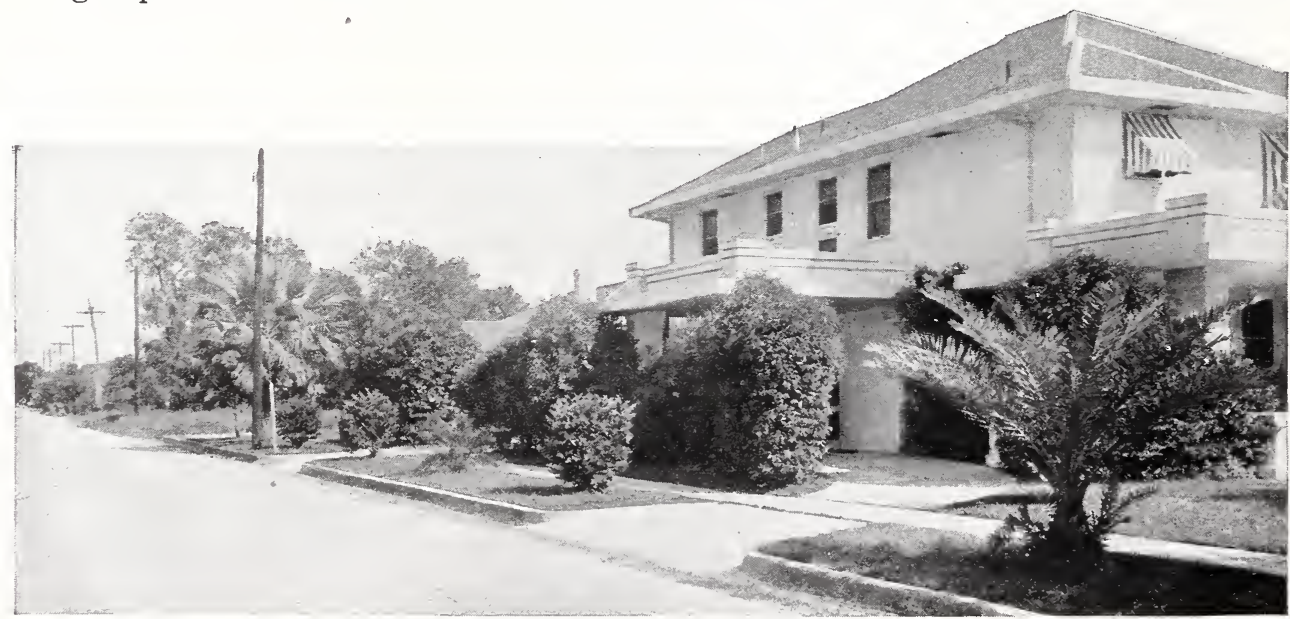

Drive Screened With Ligustrums. 


\section{Planting Instructions}

Many of our customers do not realize the importcare upon arrival. Keep the instructions given below in mind.

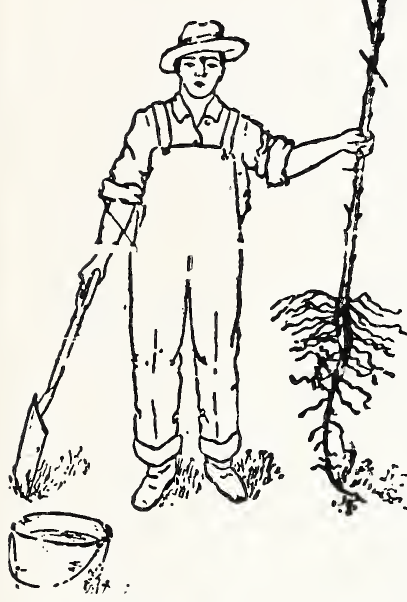

Failure to get satisfactory results in planting trees received in planting Nursery can be largely avoided if a few simple rules for pruning and planting are observed. In most cases, fallure may be traced to a lack of knowledge of the care of trees upon arrival, proper pruning and planting. the trees from the Nursery, if unable to plant immedi ately, and if the trees are dug without a ball of earth Intact (balled and bur lapped) they should be taken from the bale or box at once, counted and the Should there be a shortage, authorized substitution it should be reported directly to the general offices immediately. The trees and plants should immediately be heeled in a well drained, moist plece of sandy

Spade and Bucket of Water ground, in order that the Feady to Plant a Good Tree. soil may thoroughly pulverize between the roots.
Pack the earth thoroughly around the roots with your feet. Water freely and frequently, until the trees are planted.

If the trees are balled and burlapped, take from the crates or other containers as soon as received, set them in a shady place, and cover the balls with earth or wet straw or litter.

In Orchard Planting, the ground should be thoroughly broken, pulverized, harrowed, leveled, surveyed, or laid off with a sniall stake standing where each tree is to be planted. For the home ground, or yard, the ground should be well spaded and pulverized.

Do not use unrotted stable manure or compost fertilizer when trees are planted. A few pounds of bone meal or a few shovelfuls of well-rotted stable manure can be used at the bottom of the hole with good results at the time trees are planted. Best results with unrotted manure are attained by using it as a mulch after the trees are planted. Commercial fertilizer should be used when trees start to bud out. It is applied by digging a trench around the tree or plant, a few inches past the end of the newly planted roots. Then fill trench to cover the fertilizer.

\section{PRUNING ROOTS AND} TOPS. All broken and mutilated portions of roots should be cut off, so as to leave smooth, sound ends. the tops unpruned, until after the trees are planted. in order that the particin order that the part to ular buds they want not get broken grow might not get broker off while planting. Severe
pruning is advised, and in of the tops should be reof the tops should be reis absolutely necessary to is absolutely necessary to fore done before the trees fore done before the trees of the stock which we consider absolutely necessary to prune before shipping, are Roses, Citrus Stome Broad-leaf Everand some Broad-lear Evergreen Trees, i. e., when rooted. You should, under no circumstances, wait several days after trees are planted to prune, as moisture and strength from

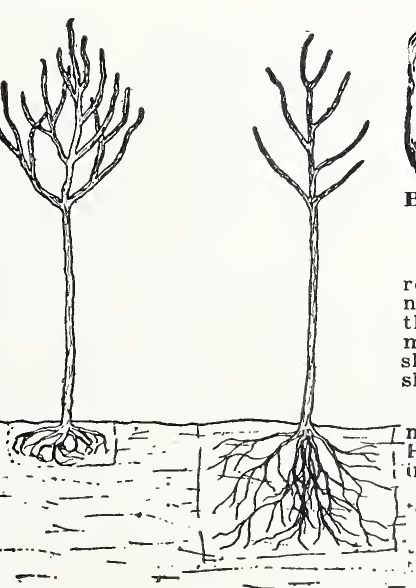
Improperly
Pruned and
Pruned and Pruned and
Planted. the body and roots of the trees. Special. illustrated, and detail instructions for planting and pruning given in Griffing's Service Bulletin No. 5

PLANTING THE TREES. We recommend using a planting board about one by four inches, six feet long. Cut a notch one inch square in the center of the beard, then bore a two-inch auger hole in each end of the board, using a round stake about one foot long, in these holes. Then place the notch in the board where the stake is set for the tree. Lift one end of the planting board off the round stake, take away the tree stake,
dig your hole large enough for the tree roots to spread out without cramping them. Then place the board back over the open hole over the round stake, and take your tree in one hand, holding it in the notch on the board and holding the top root of the tree close under the board (to prevent planting too deep). spread out the roots in their natural position with the other hand. Fine, moist, pulverized earth should be sifted in and worked around the roots after which pour in from one to three buckets of water, according to the size of the tree. Use water whether the ground is moist or not: it pulverizes the lumps and settles the soil around the roots more thor method any other coarse sticky, clay soil, it is in visable to use isable to use some sand or top are planted After the water trees soaked away, place from two to fouked away, place from two to of the land and tramp it down thoroughly; the harder it is packed the better for the trees. After the earth is thoroughly packed around the trees, mulch with manure, grass
or litter. to a depth of from three to five inches.

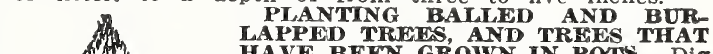
LAPPED TREES, AND TREES THAT HAVE BEEN GROWN IN POTS. Dig the holes large and deep enough to admit the ball of earth held in place by the burlap or other wrapping, so that general level of the surface is even with the top of the ball, without disturbing or removing the burlap, as it will decay in moist earth by the time the roots are ready to penetrate it. Do not crumble or disturb the earth in the ball. After this is done, fll in rich. moist, well-pulverized earth around the ball, water freely and pack firmly; rake loose earth around the tree and mulch if material is available.

PROTECTING THE TREES. If trees are planted near the walks or drives or where cattle are likely to rub them, get thoroughly established.

SHAPING THE TREES. When the new growth starts, there should be from three to five $11 \mathrm{mbs}$ allowed to grow, on most fruit trees, keeping the other sprouts off as they start growth. After these new branches have grown out from one to one and one-half feet the ends should be pinched off and orced to branch again. This should be done several times during the first Summer and the results will be-th trees will have pretty uniform shapes.

lapped Tree. $\quad$ forced to branch low to the ground and

lapped Tree. Evergreen trees and shrubs should be CULTIVATION. Unless kept thoroughly mulched as A newly planted trees from two to three inches deep, abou three or four times during the hirst summer, either by means of a cultivator or by hand. Surface dralnage should always be thorough and a basin or water puddle
should never be allowed to form about the trees.

INSECTS AND DISEASES. No plant exists that does not, in some manner, furnish food for something else Hence, all trees, Don't and fungi. Don't drive over them and let stock eat them and brosk hem down. (In some cases, people want us to replace he stock when this happens).

QUESTIONS As to future care and management of trees, receipts for spraying, etc., not covered on this page will be answered for our customers to the best of our ability. 


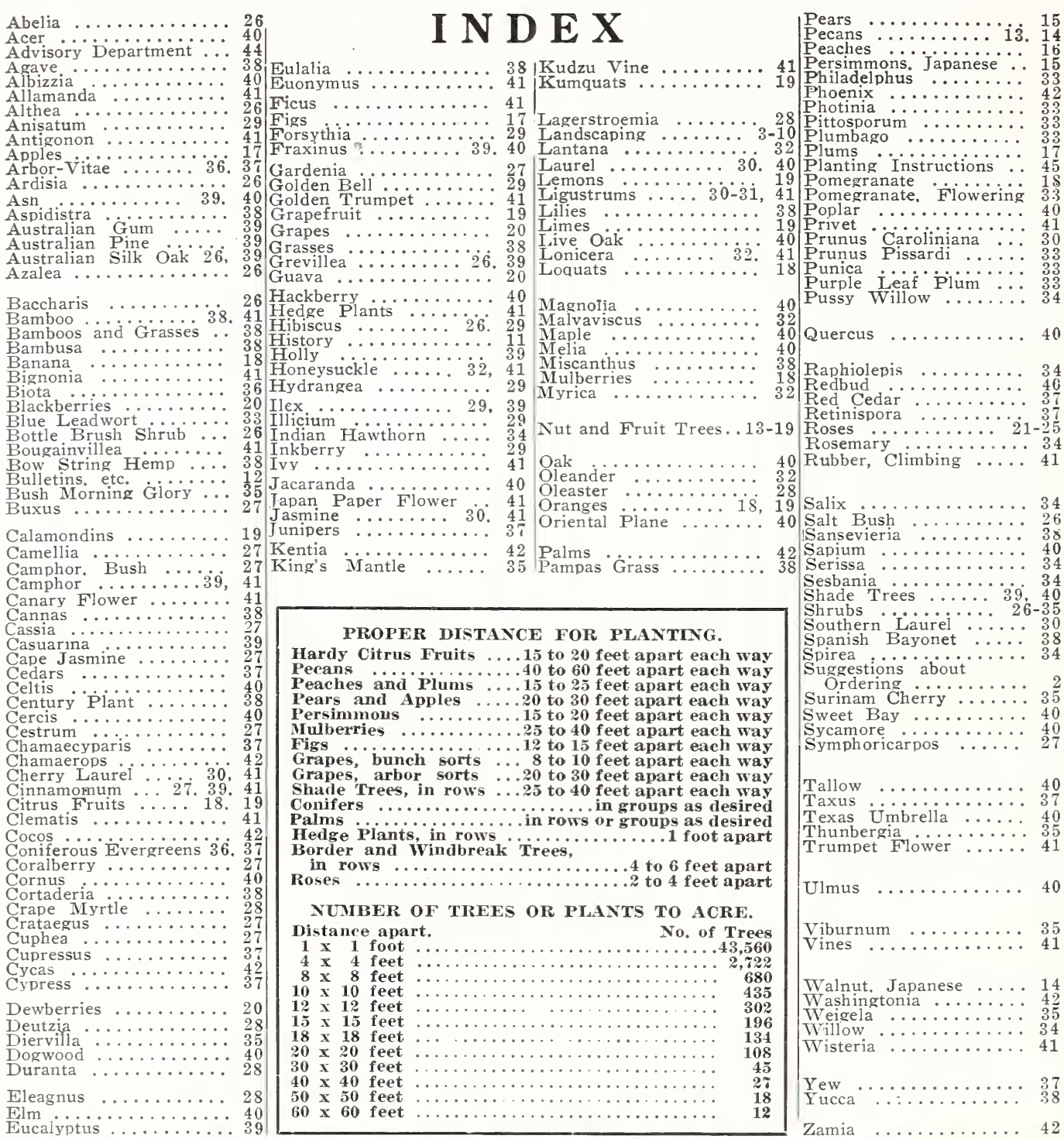

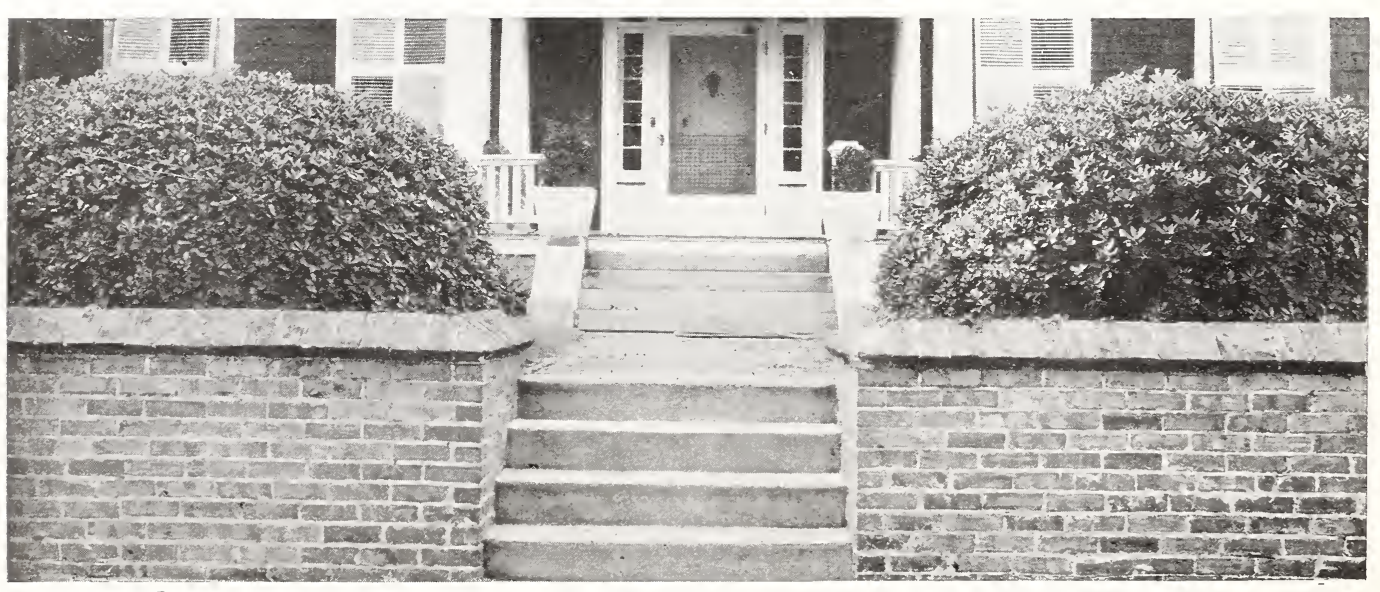

Pittosporum. 


\section{$192 \%$ \\ SPRING SURPLUS LIST Griffing's Interstate Nurseries 1560 College Street Jacksonville, Florida}

\section{TERMS:-30 DAYS NET FROM DATE OF INVOICE}

CREDITS will be extended only to those who have done satisfactory business in the past, or those having established financial ratings, or who can furnish satisfactory bank and financial references or security.

CASH ORDERS are those where full amount of bill or cost of goods is paid before shipment of goods. No charge will be made for packing where cash in full accompanies orders, or is received before shipment of goods.

SUBSTITUTION. In filling nurserymens orders we never substitute unless instructed to do so.

OUR LIABILITY AND GUARANTEE. We exercise the greatest care to keep our trees healthy and free from disease, and our varieties pure and true to name, and hold ourselves in readiness at all times to replace, on proper proof, all stock that may prove otherwise, or refund the amount paid; but it it mutually agreed between the purchaser and ourselves that we shall not at any time be liable for any amount greater than the original price paid for trees. If goods are not accepted upon these conditions, they must be returned and money will be refunded.

\section{A CASH DISCOUNT OF 5\% WILL BE ALLOWED ON ALL ORDERS WHERE REMITTANCE IN FULL ACCOMPANIES ORDER, AND NO CHARGE FOR PACKING.}

\section{Fruit and Nut Trees}

\section{PEACHES-JUNE BUDS ON PEACH ROOT}

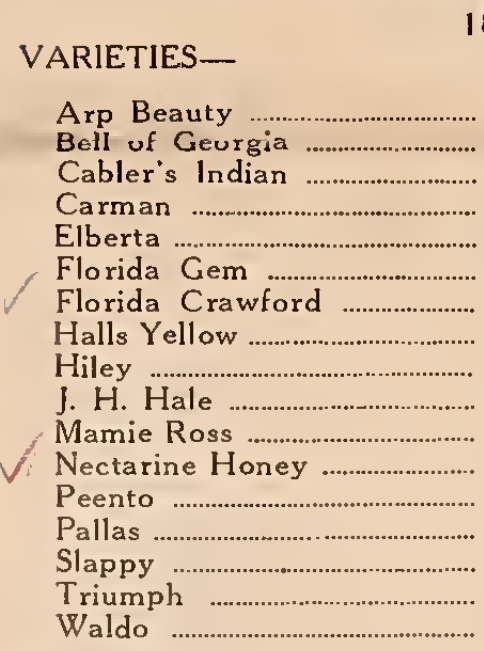

PRICES-

18 to 242 to 33 to 44 to $5 \quad 5$ to 7

18 to 24 lnches

2 to 3 Feet

3 to 4 Feet

4 to 5 Feet

5 to 7 Feet Inches

150
450
5
75
2000
10
10
65
150
265
40
50

20
30
5
110

\section{Each}

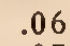

.06
.07

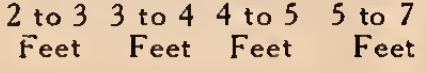

$200 \quad 75$

$250 \quad 450 \quad 35$

100

$4000 \quad 2000 \quad 500$

$\begin{array}{rrr}30 & 40 & 19\end{array}$

$50 \quad 45$

35

750

250

100

125
7

10

165

45
75

10

\section{.05}

.06

.08

.12

.18

AND THIRD

$\begin{array}{rrr}1250 & 600 & 100\end{array}$

30
75

75

$20 \quad 22$

$45 \quad 10$

$\begin{array}{ll}80 & 20 \\ 85 & 40\end{array}$

40

Per 100 Per 1000

.04

.05

.07

$\$ 37.50$

45.00

65.00

95.00

CHOICE.
$1200 \quad 1250$

\section{PEARS}

$\begin{array}{llllll}18-24 & 2-3 & 3-4 & 4-5 & 5-7 & 7-9\end{array}$ VARIETIES- Inches Feet Feet Feet Feet Ficet Pineapple.

Keiffer

…........................... $150 \quad 90$

Dixie ........................................ $75 \quad 25$

PRICES- Each Per 10 Per 100

18 to 24 Inch ............................................. $.12 \quad 1.00 \quad 9.00$

2 to 3 Feet ...................................................... $.15 \quad 1.20 \quad 10.00$

PLUMS-Peach Root $\begin{array}{llllll}18-24 & 2-3 & 3-4 & 4-5 & 5-7 & 7-9\end{array}$

VARIETIES-

Inches Feet Feet Feet Feet Feet

Burbank

Excelsior

Gonzalez

Florida ...

Happiness

Kelsey

Stumpe

Terrell

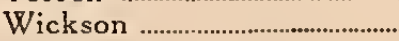

$\begin{array}{rrrr}5 & 30 & 5 & 10 \\ 250 & 175 & 70 & 40\end{array}$

1530

530

$25 \quad 10$

$\begin{array}{ccc}30 & 20 & 30 \\ & 50 & 20\end{array}$

$\begin{array}{lll}15 & 60 & 15\end{array}$

PRICES- $\quad$...... Each

18 to 24 Inches ........................................ .07

2 to 3 Feet ................................................... .08

3 to 4 Feet ................................................. .12

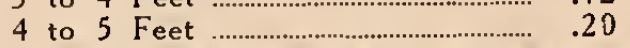

2030 
PLUM-Plum Root

$\begin{array}{lllll}18-24 & 2-3 & 3-4 & 4-5 & 5-7\end{array}$

VARIETIES- Inches Feet Feet Feet Fect

Abundance

Burbank

Excellsior

Florida.

Gonzalez ..........................................

Hoyt

Happiness

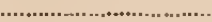

McCartney

Red June

Stumpe

Wickson

PRICES-

18 to $24 \operatorname{lnch}$

2 to 3 Feet

3 to 4 Feet

4 to 5 Feet

$150 \quad 300$

$\begin{array}{lll}175 & 275 & 140\end{array}$

$\begin{array}{rrr}15 & 600 & 425 \\ 40 & 50\end{array}$

$25 \quad 50 \quad 90$

$\begin{array}{llll}15 & 70 & 50 & 60\end{array}$

$\begin{array}{lll}175 & 100 & 40\end{array}$

$\begin{array}{rrrr}100 & 140 & & 25 \\ 30 & 150 & 80 & 60\end{array}$

$175 \quad 160$

Each Per 10 Per 100 Per 1000

$\begin{array}{rrrr}.08 & .70 & 6.00 & 55.50 \\ .10 & .90 & 8.00 & 75.00 \\ .15 & 1.40 & 13.00 & 120.00 \\ .25 & 2.00 & 18.00 & 160.00 \\ 30 & 2 . j 0 & 23.00 & \end{array}$

PECANS-Budded and Grafted Paper Shell Varieties.

VARIETIES-

Stuart

Schley

Money Maker .........

Teche

Moore

Success

PRICES-

2 to 3 Feet

3 to 4 Feet

4 to 5 Feet

5 to 6 Feet

6 to 8 Feet
Sizes can Supply

2-3 Ft. $\quad 3-4 \mathrm{Ft} . \quad 4-5 \mathrm{Ft} . \quad 5-6 \mathrm{Ft} . \quad 6-8 \mathrm{Ft}$. 2-3 Ft. 3-4 Ft. 4-5 Ft. 5-6 Ft. 6-8 Ft.

$2-3 \mathrm{Ft}$. $5-6 \mathrm{Ft}$. $6-8 \mathrm{Ft}$.

$2-3 \mathrm{Ft} . \quad 3-4 \mathrm{Ft} . \quad 4-5 \mathrm{Ft} . \quad 5-6 \mathrm{Ft} . \quad 6-8 \mathrm{Ft}$.

3-4 Ft. 4-5 Ft. 5-6 Ft. 6-8 Ft.

$4-5 \mathrm{Ft} . \quad 5-6 \mathrm{Ft} . \quad 6-8 \mathrm{Ft}$.

Each Per 10 Per 100

$.50 \quad 4.50$

$.60 \quad 5.50$

$\begin{array}{ll}.70 & 6.50\end{array}$

$.80 \quad 7.50$

.90

7.50
8.50

40.00

50.00

60.00

70.00

80.00

\section{JAPAN PERSIMMON}

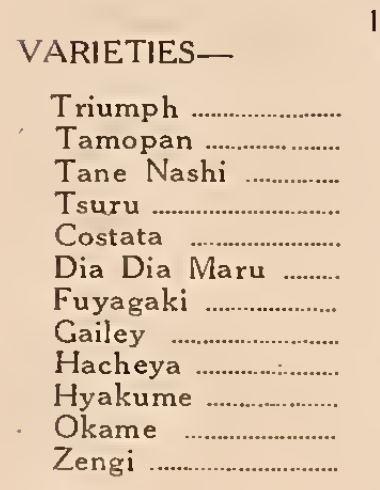

$18-24 \quad 2-3 \quad 3-4$

Inch Feet Feet

4-5

Feet

$5.7 \quad 2$

$\begin{array}{lll}90 & 90 \quad 65\end{array}$

$\begin{array}{lll}190 & 275 \quad 190\end{array}$

1900

65

20

50
300

300
20

190

125

275
65

4000

65

7000
30

40
40

Feet Year

40

500

225

40

300
40

Each

PRICES-

.12

.15

.15

.30

.40

.50

50
90
500
30
90
65
400
40

Per 10

1.10

1.3 .0

1.80

2.50

3.50

4.50

$\begin{array}{rrr}45 & 275\end{array}$

$900 \quad 1200$

$60 \quad 50 \quad 150$

$\begin{array}{lll}50 & 30 & 125\end{array}$

$\begin{array}{lll}200 & 125 & 350\end{array}$

$5 \quad 600$

$\begin{array}{lll}65 & 20 \quad 600\end{array}$

$\begin{array}{lll}25 & 10 & 275\end{array}$

$120 \quad 65$

$10 \quad 20$

FIGS

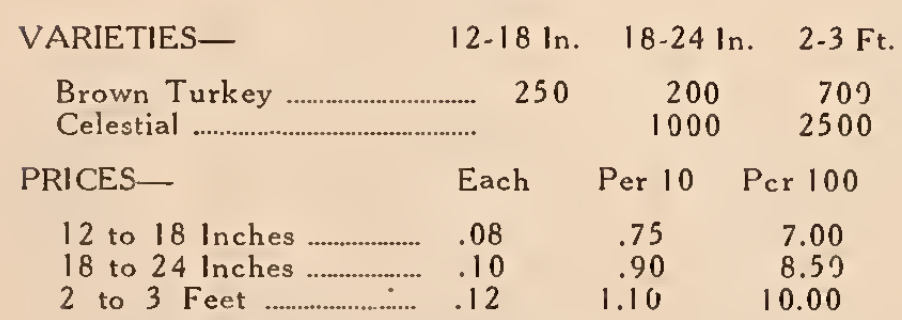

16.00

20.00

115.00

145.99
50

35
60

Evergreen and Deciduous Shrubs

ABELIA GRANDIFLORA-

Price Per Per

18 to 24 Inches

Each 10

100

ALTHEA OR ROSE OF SHARON-

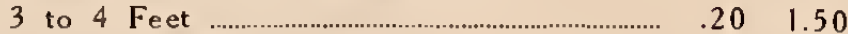

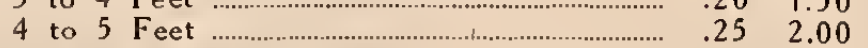

ARDESIA JAPONICA--

$21 / 2$ inch Pots

4 inch Pots

$\begin{array}{lll}.20 & 1.50 \quad 14.00\end{array}$

BANANAS-Ornamental.

6 inch Pots

$40 \quad 3.50$

CAMPHOR-Bushy.

18 to 24 lnches

2 to 3 Feet

3 to 4 Feet

15

$20 \quad 1.75$

CAPE JASMINE-Grandiflora \& Florida.

8 to 12 Inches

12 to 18 Inches

18 to 24 Inches

2 to 3 Feet

$\begin{array}{ll}.75 & 15.00\end{array}$

CORALBERRY - Symphoricarpos Vulgaris.

2 to 3 Feet

$.20 \quad 1.75$

$.25 \quad 2.25$

$.30 \quad 2.75$

$.40 \quad 3.75$

15.00

29.00

25.00

CUPHEA HYSSOPIFOLIA-

$21 / 2$ inch Pots

$15 \quad 1.25$

4 inch Pots

.252 .0

10.00

ELEAGNUS PUNGENS-

18 to 24 Inches

$\begin{array}{ll}40 & 3.50\end{array}$

2 to 3 Feet.

$.60 \quad 5.50$

ELEAGNUS PUNGENS VARIEGATA-

2 to 3 Feet

.70

6.50

LANTANA-Weeping \& Bush Kinds.

4 inch Pots

$.25 \quad 2.00$

17.50

MYRICA CERIFERA-Collected Seedlings.

1 to 2 Feet

2 to 3 Feet

CRAPE MYRTLE-Pink, Crimson, Purple.

(few White)

18 to 24 Inches

2 to 3 Feet.

3 to 4 Feet

$\begin{array}{lll}.40 & 3.00 & 25.00\end{array}$

$.50 \quad 4.00 \quad 35.30$

Deutzia-Candidissima, Double White.

Crenata, Single White.

Pride of Rochcster, Pink and White.

3 to 4 Feet

$2.0 \quad 1.75$

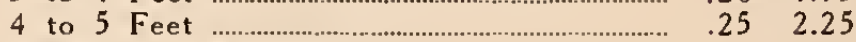

EUGENIA HOOKERIANA-

6 inch Pots

$.50 \quad 4.50$

40.00

ILEX GLABRA-Inkberry.

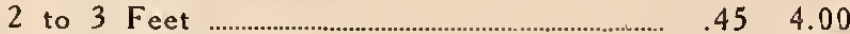

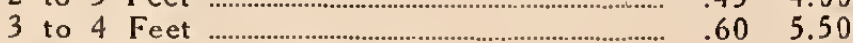

4 to 5 Feet …....................................................... $.75 \quad 6.50$

ILLICIUM ANISATUM-Anise.

18 to 24 Inchcs B \& B.

$1.25 \quad 10.00$

2 to 3 Feet $B$ \& B..................... 1.50 I 2.50

LAUREL CHERRY-Prunus Caroliniana, Bushy.

2 to 3 Feet ..................................................................

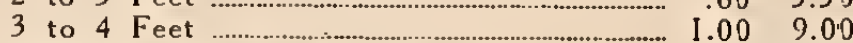

LIGUSTRUM-Lucidum \& I wata.

18 to 24 Inches $B$ \& B

$\begin{array}{lll}1.00 & 9.00 \quad 80.00\end{array}$

2 to 3 Feet $B$ \& $B$.

$\begin{array}{lrr}1.25 & 11.50 & 100.03\end{array}$

I yr. nat. growth, Grafted Plants. 
LIGUSTRUM-Lucidum \& Iwata.

$\begin{array}{lcc}\text { Price } & \text { Per } & \text { Per } \\ \text { Each } & 10 & 100\end{array}$

2 \& 3 yr. specimen, Grafted plants that

have been cut back and pruned several times.

18 to 24 Inches B \& B

2 to 3 Feet $B$ \& $B$

3 to 4 Feet $B$ \& B

LIGUSTRUM-Nobilis, Japonica
2 to 3 Feet
B \& B.
3 to 4 Feet
I yr. natural growth, grafted plants.

LIGUSTRUM LUCIDUM-Lining out stock.

Rooted cuttings from frames

4 to 6 Inches ............................ 7.50 per 100

OLEANDER-Pink and White.

Note-All Oleanders cut back severally account tops having been frozen, but will make handsome plants by early summer. 18 to 24 Inches

2 to 3 Feet

3 to 4 Feet

PHOTINIA SERRULATA-

18 to 24 Inches B \& B

2 to 3 Feet $B$ \& B

65.09 per 1000

PITTISPORUM TOBIRA-

Field Grown Specimens, Small.

15 to 18 Inches $B$ \& $B$

Field Grown Specimens, Large.

18 to 24 Inches B \& B

$2.00 \quad 17.50$

PURPLE LEAF PLUM-Prunus Pissardi.
4 to 5 Feet
$40 \quad 3.50$
5 to 7 Feet
PUSSY WILLOW-Salix Discolor.

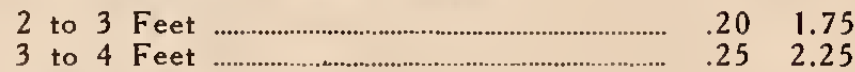
4 to 5 Feet .................................................................................. $.35 \quad 3.25$
SPIREA-Van Houttei.
18 to 24 Inches $\quad .12 \quad 1.00$

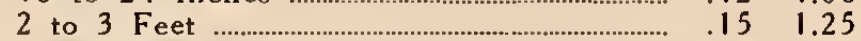
3 to 4 Feet …………………………………………………........ . .20

\section{Coniferous Evergreens}

Price Per

BIOTA ROSEDALE-

Each 10

12 to 15 Inches $B$ \& $B$

15 to 18 Inches $B$ \& $B$

$.90 \quad 8.00$

18 to 24 Inches B \& B

$1.10 \quad 10.00$

1.3512 .50

BIOTA AUREA CONSPICUA-
2 to 3 Feet
$B$ \& $B$.
3.00

BIOTA AUREA NANA-

12 to 15 Inches $B$ \& $B$.

15 to 18 Inches $B$ \& $B$

$1.15 \quad 10.00$

18 to 24 Inches $B$ \& B

$1.35 \quad 12.50$

$\begin{array}{ll}1.75 & 16.00\end{array}$

BIOTA BONITA-

12 to 15 Inches $B$ \& $B$

15 to 18 Inches $B$ \& $B$.

$1.15 \quad 10.00$

18 to 24 Inches B \& B.

$\begin{array}{lll}1.35 & 12.50\end{array}$

BIOTA COMPACTA-

12 to 15 Inches $B$ \& $B$

1.7516 .00

15 to 18 Inches $B$ \& B

$.90 \quad 8.00$

18 to 24 Inches B \& B.

$\begin{array}{rr}1.10 & 10.00\end{array}$

$\begin{array}{ll}1.35 & 12.50\end{array}$

BIOTA TEXANA GLAUCA-

3 to 4 Feet $B$ \& B

2.5020 .00

4 to 5 Feet B \& B.

3.0025 .00

ITALIAN CYPRESS-

Sizes 2 to 8 Feet B \& B Per Foot.
RETINISPORA OBTUSA-

Price Per

2 to 3 Feet $B$ \& B....

3 to 4 Feet $B$ \& $B$.

Each 10

100

4 to 5 Feet

$\mathrm{B}$ \& $\mathrm{B}$.

$2.00 \quad 17.50$

RETINISPORA PLUMOSA-

15 to 18 Inches $B$ \& B

18 to 24 Inches B \& B

2 to 3 Feet $B$ \& B

RETINISPORA PLUMOSA AUREA-

15 to 18 Inches $B$ \& B.

18 to 24 Inches B \& B

$2.75 \quad 25.00$

3.5032 .50

2 to 3 Feet $B$ \& B.

RETINISPORA SQUARRASA VEITCHI-

18 to 24 Inches $B$ \& B

24 to 30 Inches $B \& B$

$1.10 \quad 10.00$

1.2511 .50

$1.60 \quad 15.00$

30 to 36 Inches $B$ \& $B$.

$1.10 \quad 10.00$

1.2511 .50

$1.60 \quad 15.00$

$1.75 \quad 16.00$

$2.00 \quad 18.00$

$\begin{array}{ll}2.75 & 25.00\end{array}$

CEPHALETAXUS DRUPACEA-

6 Inch Pot, 20 Inches High

1.25

LIBOCEDRUS DECURRENS-

18 to 24 Inches $B$ \& B.

24 to 30 Inches $B$ \& B

$1.50 \quad 12.50$

$2.25 \quad 20.00$

30 to 36 Inches B \& B

3.0027 .59

JAPANESE JUNIPER-

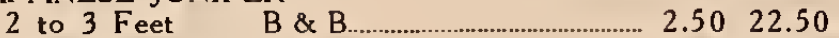

3 to 4 Feet $B$ \& $B$.

$\begin{array}{ll}2.50 & 22.50 \\ 3.00 & 27.50\end{array}$

CEDAR DEODARA-

2 to 3 Feet B \& B

$2.75 \quad 25.00$

3 to 4 Feet $B$ \& B

$4.00 \quad 37.50$

JUNIPERUS VIRGINIANA-Red Cedar.
5 to 7 Feet
$B$ \& $B$
$4.50 \quad 42.50$
7 to 9 Feet
$B$ \& $B$
$6.00 \quad 55.00$
9 to 12 Feet
$B$ \& $B$.
8.0075 .00

TEA PLANTS-Camellia Thea.

$21 / 2$ Inch Pots

$.20 \quad 1.75$

15.00

\section{Bamboos, Grasses and Miscellaneous Plants}

BAMBOO-Argentea, Argentea.

Striata, Verticitlata \& Falcata Varieties.

4 to 6 canes

6 to 8 canes

8 to 12 canes

12 to 15 canes

GRASSES-Eulalia, Univittata Variegata

Zebrina, Pampas.

6 Inch Pots 10 to 12 Leaves

Price Per Per

Each $10 \quad 100$

$40 \quad 3.50$

$.50 \quad 4.50$

$.60 \quad 5.50$

.757 .00
4 to 6 canes.

6 to 8 canes

8 to 12 canes

12 to 15 canes

ASPIDISTRA LURIDA-

CALPHYA MOSAICA-

3 Inch Pots .......................

5 Inch Pots

YUCCA FELLAMENTOSA-

$21 / 2$ Inch Pot

2 yr. Clumps 20 to 24 Inches

ANNAS-

King Humbert-Bronze.

Indiana-Orange.

Wyoming-Orange.

Pennsylvania-Scarlet

BIRDS EYE CACTUS-

21/2 Inch Pots

CAPE JASMINE-Lining Out Stock.

4 to 6 Inch ................................... 6.00 per 100 PASSION FLOWER-White

6 inch Pots

$.40 \quad 3.50$

.5004 .50

$60 \quad 5.50$

$.75 \quad 7.00$

$1.50 \quad 12.50$

17.50

$.65 \quad 6.00 \quad 50.00$

$\begin{array}{llr}.10 & .90 & 8.00\end{array}$ $.50 \quad 4.00 \quad 35.00$
30.00 per 1900

$.10 \quad .90 \quad 8.00$

50.00 per 1000

$\begin{array}{lll}60 & 5.00 \quad 45.00\end{array}$
.252 .00 


\section{Shade and Ornamental Trees}

Price Per Per $\begin{array}{lll}\text { Each } & 10 \quad 100\end{array}$

AUSTRALIAN PINES-

Cunningham and Stricta Varieties.

6 inch Pots 4 to 5 Feet

$\begin{array}{ll}.75 & 7.00\end{array}$

AUSTRALIAN SILK OAK-

Pots 12 to 18 Inches.

Pots 18 to 24 Inches.

Avocado Bores 4 to 5 Feet

1.35

1.60

2.10

7.90

CAMPHOR TREES-
2 to 3 Feet
3 to 4 Feet
4 to 5 Feet
5 to 6 Feet

1.75

2.75

4.75

7.00

ILEX OPACA-American Holly.

18 to 24 Inches

6 to 8 Feet

$.35 \quad 3.00$

8 to 10 Feet

$\begin{array}{ll}2.50 & 22.50\end{array}$

3.5032 .50

ILEX MYRTIFOLIA-Myrtle Leaf Holly.

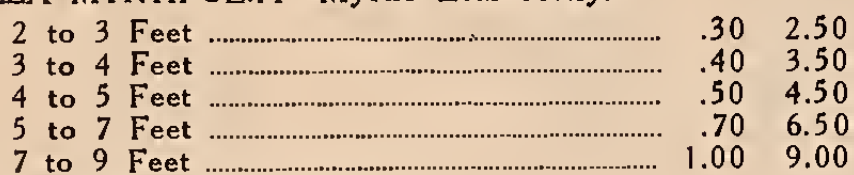

JACARANDA MIMOSIFOLIA-

5 Inch Pots

$.60 \quad 5.00$

45.00

MAGNOLIA GRANDIFLORA-

4 to 5 Feet

$1.25 \quad 11.00$

MAGNOLIA GLAUCA-

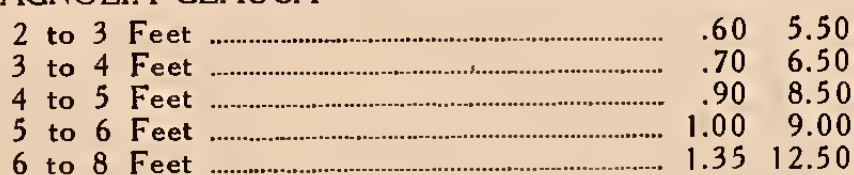

OAKS-Live Oak (Virginiana)

4 to 6 Feet

$\begin{array}{lll}.60 & 5.50 & 50.00\end{array}$

6 to 8 Feet

Laurel Oak (Water Oak)

4 to 6 Feet

6 to 8 Feet

8 to 10 Feet

10 to 12 Feet

$.50 \quad 4.50 \quad 40.00$

$\begin{array}{lll}.70 & 6.50 & 60.00\end{array}$

$\begin{array}{rrr}90 & 8.50 & 80.00\end{array}$

$\begin{array}{lll}1.25 & 13.50 & 125.00\end{array}$

HACKBERRY-Celtis Sinensis.

8 to 10 Feet

$1.00 \quad 9.00$

MAPLE-Soft.

2 to 3 Feet

3 to 4 Feet

4 to 5 Feet

$\begin{array}{lll}15 & 1.35 & 12.00\end{array}$

$\begin{array}{lll}.20 & 1.85 & 17.50\end{array}$

$\begin{array}{lll}30 & 2.75 & 25.00\end{array}$

POPLAR-(Lombardy)

2 to 3 Feet ......................

3 to 4 Feet

$\begin{array}{lll}.15 & 1.35 & 12.50\end{array}$

RED BUD-Cercis Canadensis.

3 to 4 Feet

4 to 6 Feet

$.20 \quad 1.85$

17.50

ILEX DAHOON-

2 to 3 Feet

3 to 4 Feet

4 to 5 Feet

\section{Hedge Plants}

AMOOR RIVER PRIVET-

2 to 3 Feet

4.00 per $100 \quad 35.00$ per 1000

3 to 4 Feet

5.09 per 100

45.00 per 1000

CALIFORNIA PRIVET-

18 to 24 Inches

3.00 per $100 \quad 25.00$ per 1000

CHERRY LAUREL-Seed Bed Stock.

7.00 per $100 \quad 60.00$ per 1900

\section{Vines}

HONEYSUCKLE-Chinese, Halls Japan,

Price Per

Each 10

Golden Netted Varieties.

Strong

$.50 \quad 4.50$

CLEMATIS PANICULATA-

21/2 Inch Pots

$.20 \quad 1.50$

IVY-English and Boston.

$21 / 2$ Pots

$.20 \quad 1.50$

BIGNONIA SPECIOSA-

From Pots, Medium

$.50 \quad 4.50$

\section{Palms}

CHAMAEROPS EXCELSA-

Price Per Per

Each $10 \quad 100$

1 to 2 Feet $B$ \& $B$ $1.25 \quad 10.09$

PHOENIX CANARIENSIS-

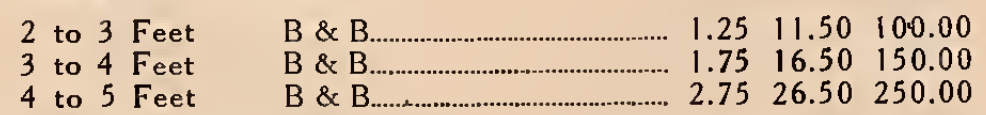

WASHINGTONIA ROBUSTA-
2 to 3 Feet
$B$ \& $B$
$\begin{array}{lll}1.25 & 11.50 & 109.00\end{array}$
3 to 4 Feet
$\mathrm{B} \& \mathrm{~B}$
$\begin{array}{llll}1.75 & 16.50 & 150.00\end{array}$
4 to 5 Feet
$\mathrm{B} \& \mathrm{~B}$
5 to 6 Feet
$\mathrm{B} \& \mathrm{~B}$
$\mathrm{B} \& \mathrm{~B}$
$26.50 \quad 250.00$
6 to 8 Feet

COCOS AUSTRALIS-

2 to 3 Inch Cal. B \& B

3 to 4 Inch Cal. B \& B..

$3.00 \quad 25.00$

4 to 5 Inch Cal. B \& B

$4.00 \quad 35.90$

$5.00 \quad 45.00$

COCOS PLUMOSA-In Boxes.
2 to 3 Feet
$\begin{array}{ll}1.75 & 15.00\end{array}$
3 to 4 Feet
$3.00 \quad 27.50$

NOTE-Can supply most sizes of Phoenix, Washingtonia and Cocos Australis established in tubs at an increase of $\$ 1.50$ each over prices listed above. 


\section{OUR PATRONS WILL OBLIGE US BY USING THIS ORDER SHEET. \\ READ TERMS OF SALE, PAGE 2 . \\ Griffing's Interstate Nurseries}

\section{Jacksonville, Fla.}

For amount enclosed, $\$$

Send me on

(Specify about date wanted).

By

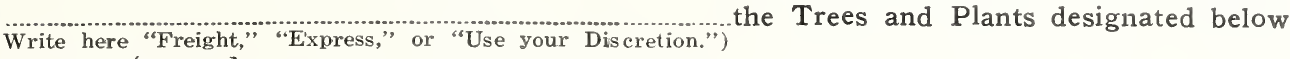
Name $\left\{\begin{array}{l}\text { Mrs. } \\ \text { Mr. } \\ \text { Miss }\end{array}\right\}$

Street and Number

Post Office

\section{State}

Express or Freight Office

We substitute unless instructed to the contrary, but never until the varieties ordered are exhausted. If you do not want us to substitute in case we are out of the varieties or sizes, write the word "NO" here

in which case we will refund for shortage,

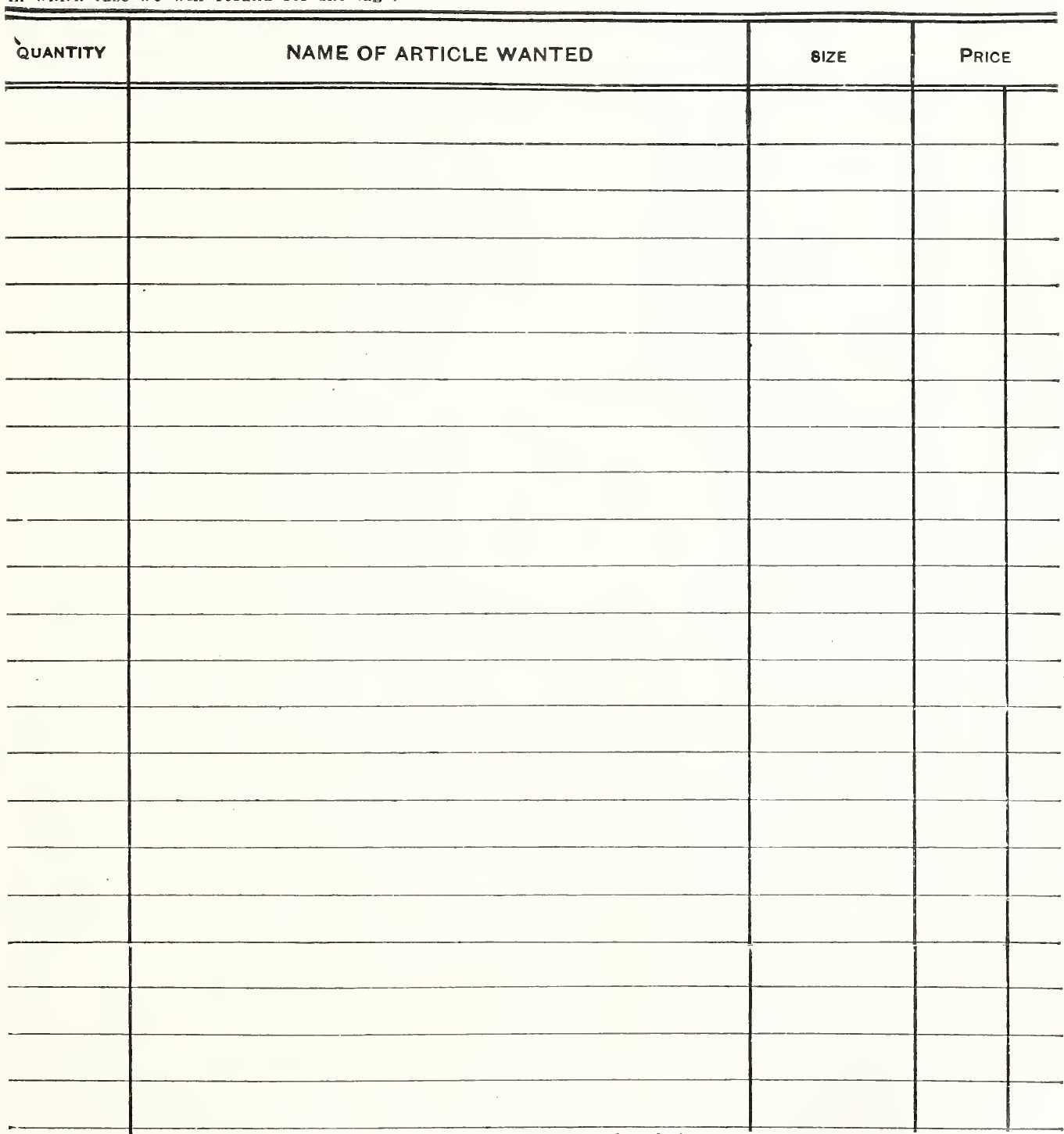




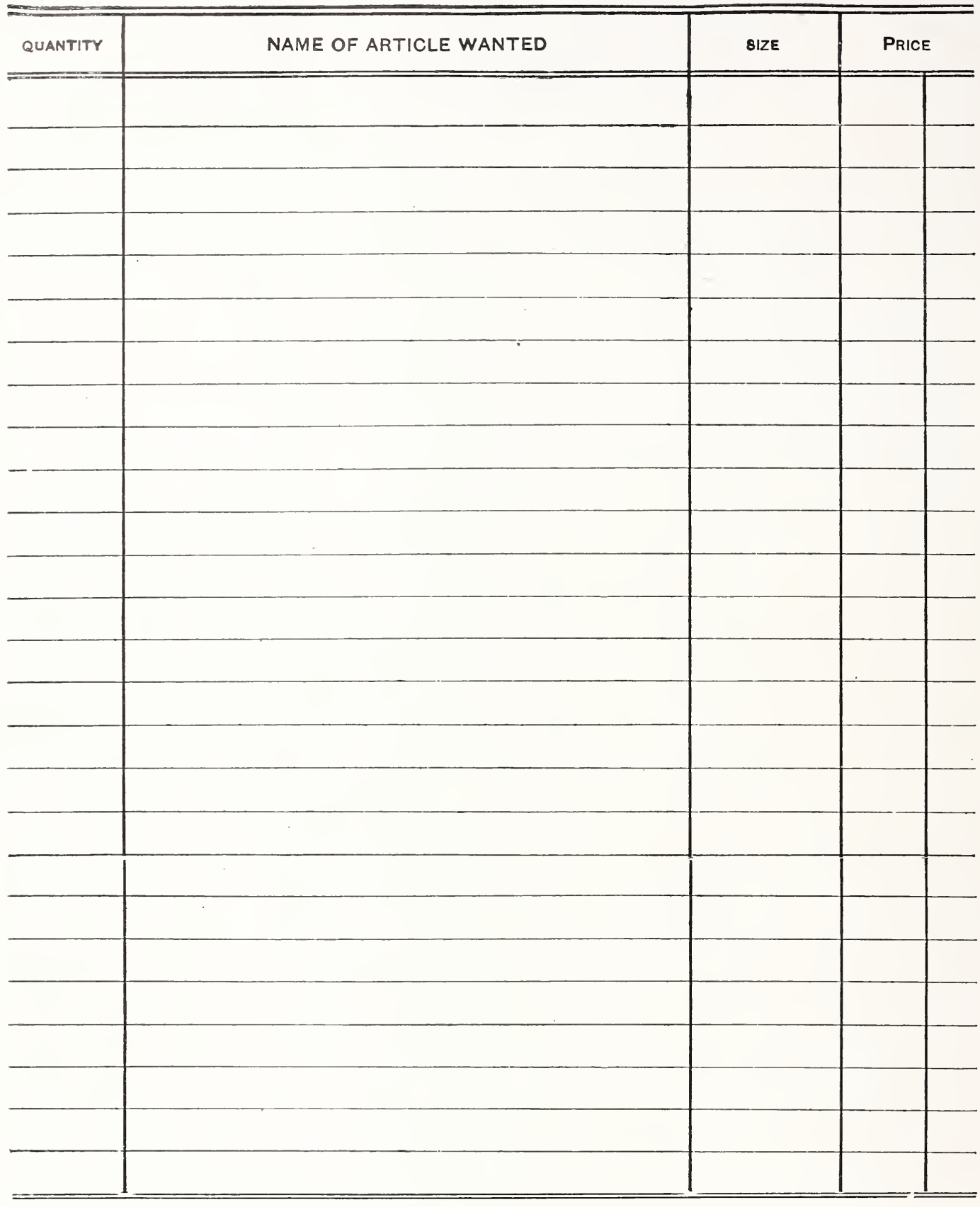

If 'you have friends or neighbors you believe will be interested in our catalog please write their names below. Thank you.

NAME

ADDRESS 


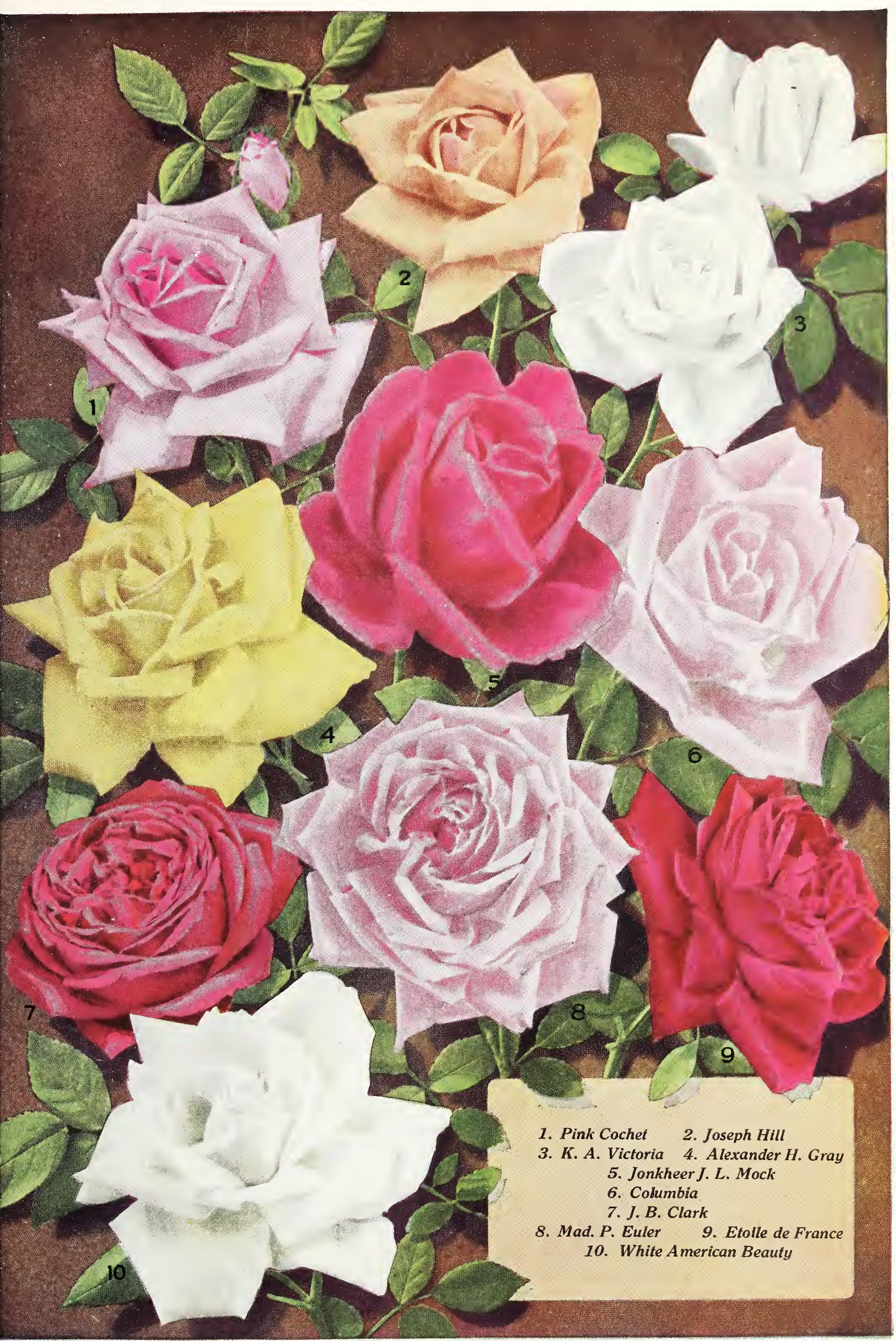


